Digitized by the Internet Archive in 2016 


\section{NUTRITION AND FEEDING MANAGEMENT FOR HORSE OWNERS}

Susan Novak, Ph. D

Anna Kate Shoveller, Ph. D

With contributions by Lori K. Warren, Ph. D 


\section{Published by:}

Alberta Agriculture and Rural Development

Information Packaging Centre

7000-113 Street

Edmonton, Alberta

Canada T6H 0T6

Editor: Ken Blackley

Graphic Designer: Perpetual Notion Design Inc.

Copyright (C) 2008. Her Majesty the Queen in Right of Alberta (Alberta Agriculture and Rural Development) All rights reserved

No part of this publication may be reproduced, stored in a retrieval system, or transmitted in any form or by any means, electronic, mechanical photocopying,recording, or otherwise without written permission from the Information Packaging Centre, Alberta Agriculture and Rural Development.

\section{ISBN 0-7732-6078-1}

Copies of this publication may be purchased from:

Publications Office

Alberta Agriculture and Rural Development

Phone: 1-800-292-5697 (toll-free in Canada) or (780) 427-0391

or

see our website www.agriculture.alberta.ca/publications for information on other information products. 


\section{TABLE OF CONTENTS}

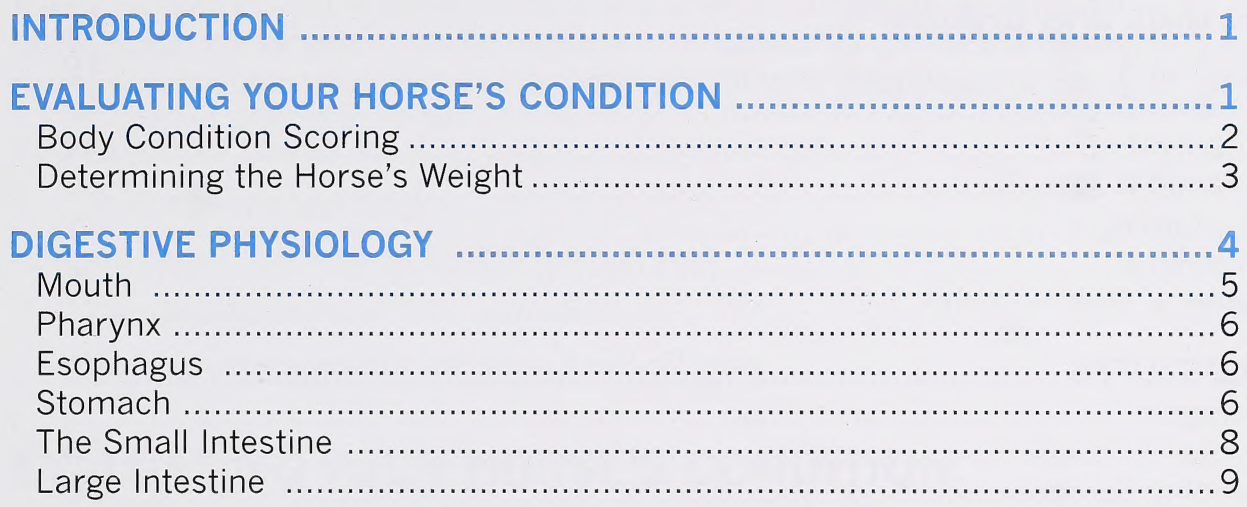

NUTRIENTS AND THEIR FUNCTIONS .................................. 11

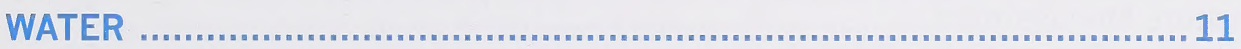

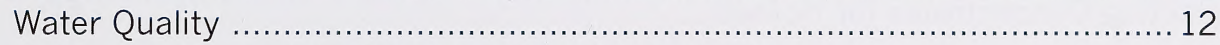

Water and Electrolyte Considerations for Active Horses .......................... 15

General Tips: Water ............................................................... 15

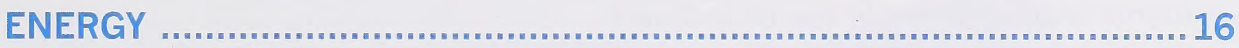

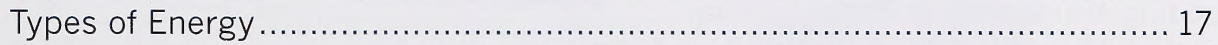

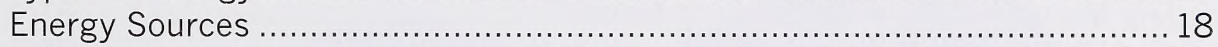

Feed Analysis for Horses: Digestible Energy ...................................... 19

Energy Requirements ................................................................. 20

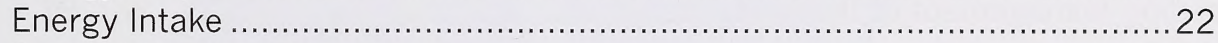

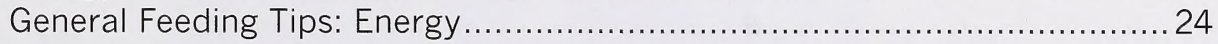

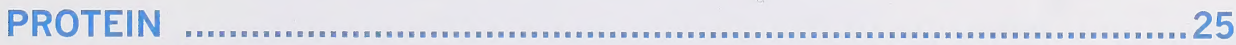

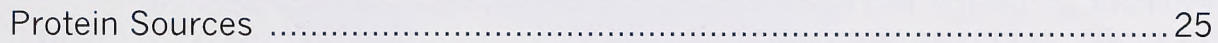

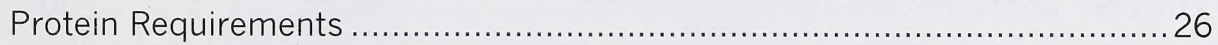

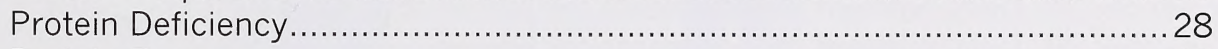

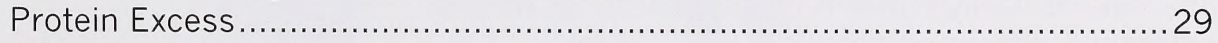

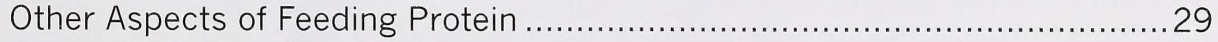

General Feeding Tips: Protein ..................................................... 30

MINERALS FOR HORSES .................................................... 31

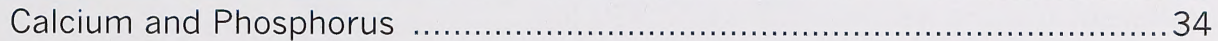

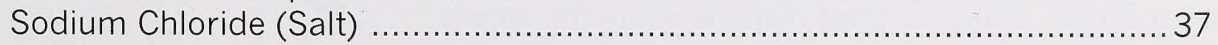

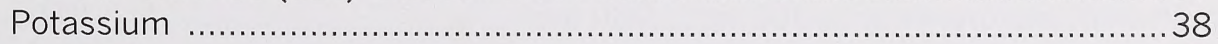

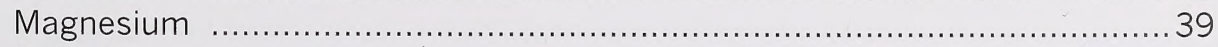

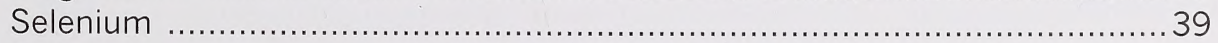

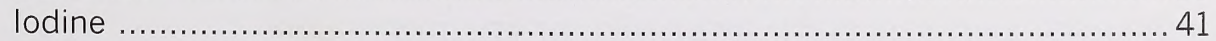

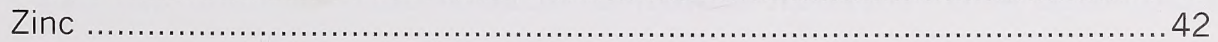

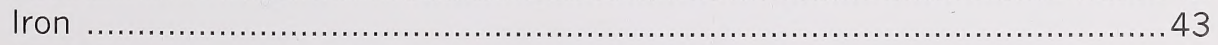

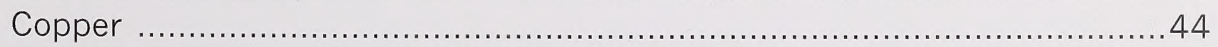




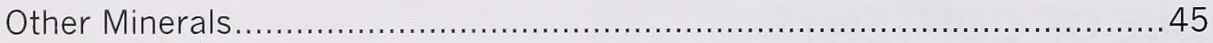

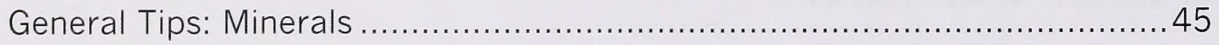

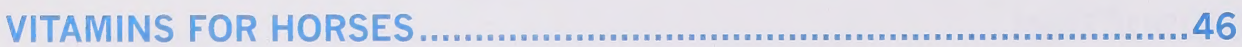

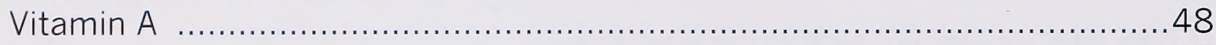

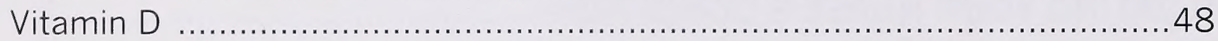

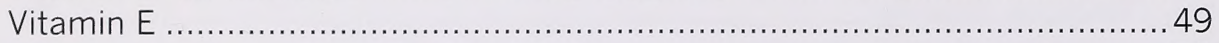

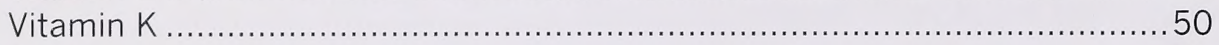

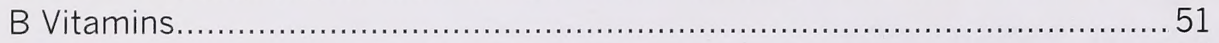

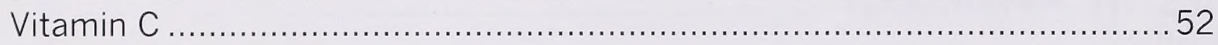

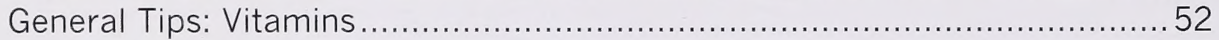

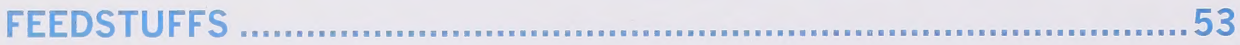

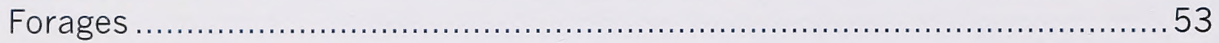

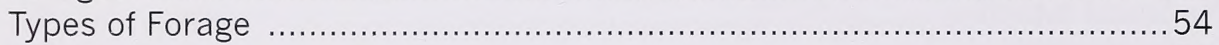

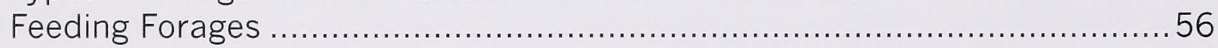

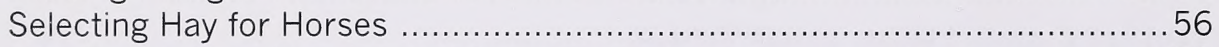

How To Get Your Hay Analyzed .................................................... 58

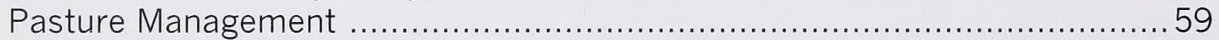

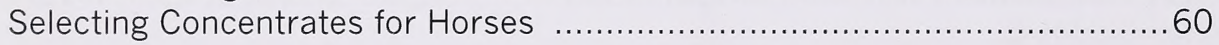

FEEDING MANAGEMENT ............................................... 71

Feeding the Mature, Idle Horse: Maintenance ...................................... 71

Nutritional Management of the Broodmare ......................................... 71

Feeding Management of the Stallion.................................................. 78

Feeding Management of the Growing Horse ..................................... 81

Feeding Management of the Performance or Working Horse ....................85

Feeding Management Over Winter ...................................................... 90

Feeding Management of the Aging Horse.............................................. 91

APPENDIX 1. TYPICAL NUTRIENT VALUES FOR HORSE FEEDS .........96

APPENDIX 2. DAILY NUTRIENT REQUIREMENTS FOR HORSES OF

DIFFERENT MATURE WEIGHTS ................................................. 100

Appendix 2A. Daily nutrient requirements for ponies-200 kg (440 lbs) ...... 100

Appendix 2B. Daily nutrient requirements for horses

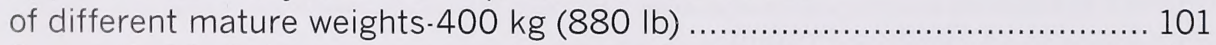

Appendix 2C. Daily nutrient requirements for horses

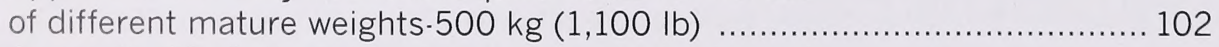

Appendix 2D. Daily nutrient requirements for horses

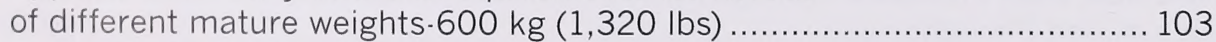

Appendix 2E. Daily nutrient requirements for horses

of different mature weights-900 kg (1,980 lbs) .................................. 104

GLOSSARY .............................................................................. 105

REFERENCES AND FURTHER READING/RESOURCES $\ldots \ldots \ldots \ldots \ldots \ldots \ldots . \ldots \ldots$ 


\section{INTRODUCTION}

With all of the feeds and feedstuffs available for horses, it is difficult to be confident that the feeding choices made are the best for the horse. This manual will provide information on horse nutrition and nutritional content of feeds so that good horse feeding programs can be designed.

This manual will cover:

- basic digestive physiology

- the horse's requirements for different nutrients

- the nutrient content of different feeds

- feeding management for different classes of horses

\section{EVALUATING YOUR HORSE'S CONDITION}

The best way to assess if the horse is eating the right amount of feed is to look at the horse's body condition score (Table 1 and Figure 1). Feed the horse to maintain an ideal body condition score of 4 to 6 . Broodmares should ideally be between 5 and 7 .

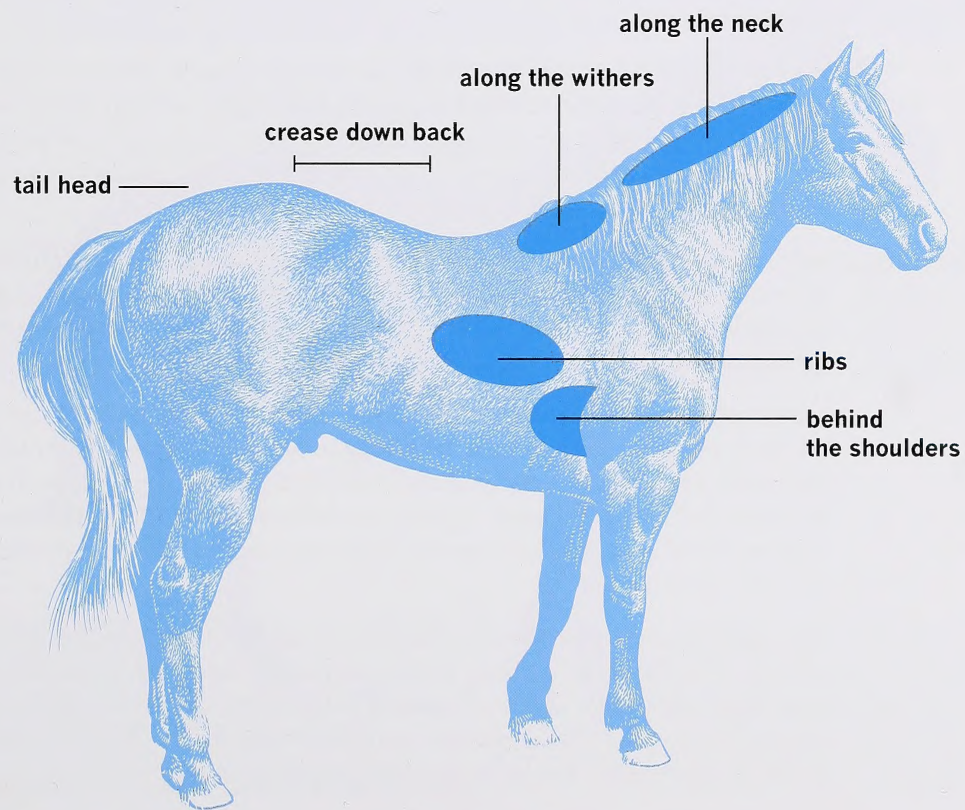

Figure 1. Important areas to assess levels of fatness when body condition scoring. 


\section{BODY CONDITION SCORING}

Body Score

1. Poor

2. Very Thin

3. Thin

4. Moderately thin

6. Moderately fleshy

8. Fat

9. Extremely fat

\section{Description}

Horse is extremely emaciated. The individual vertebrae of the spinal column, the ribs, and around the base of the tail are easily seen. In addition, the bone structure of the withers, shoulders and neck are easily noticeable and no fatty tissue can be felt. A body condition score of 1 indicates inadequate energy intake.

Horse is emaciated; however, a slight amount of tissue is covering over the spinal region making the vertebrae feel a little more rounded than in a body condition score of 1 . The ribs, tailhead, withers, shoulders and neck bones are still easily noticeable but a slight amount of tissue covers these bones. A body condition score of 2 indicates inadequate energy intake.

At this body score, the spinal column has enough fat surrounding it that only the top part of the spinal column will be prominent, while the edges will feel a little more rounded. There will be a slight fat cover over the ribs but these will still be discernible to the eye as will the tailhead. Individual vertebrae cannot be identified. Withers, shoulders and neck will not appear obviously thin. A body condition score of 3 indicates inadequate energy intake.

A slight ridge (the top of the vertebrae) will be discernible to the eye and a faint outline of the ribs can be seen. Whether the tailhead is discernible generally depends on the breed of the horse. The withers, shoulders and neck will not appear obviously thin.

Back is flat (no ridge is discernible); ribs are not visually discernible but can be felt. The fat around the tailhead begins to feel slightly spongy. The withers will be rounded around the spinal processes and the shoulders and neck blend smoothly into the rest of the body. A body score of 5 indicates the proper amount of dietary energy intake is being met.

May have a slight crease down the spinal column (looks like a slight trench from the top of the croup to the withers). The fat covering the ribs and at the tailhead feel spongy. Fat will begin to be deposited along the side of the withers, behind the shoulders and along the sides of the neck.

Likely will have a crease down the spinal column. Individual ribs can be felt but they will feel like they have fat filling in between them. The tailhead will be noticeably spongy and there will be fat deposited along the withers, behind the shoulder and along the neck. A body condition score of 7 indicates energy intake is in excess of energy requirements, however a score of 7 is still considered within ideal for a broodmare.

Noticeable crease down the horse's back. It will be difficult to feel the ribs at all and the fat around the tailhead will be very soft. The area around the withers and behind the shoulders will be deposited with fat and the neck will be noticeably larger. There may be fat deposited along the inner thighs. A body condition score of 8 indicates energy intake is in excess of energy requirements.

Very obvious crease down the back. There may be patchy fat spots appearing over the ribs and there will be bulging fat around the tailhead, along the withers, behind the shoulders and along the neck. The fat along the inner thighs may rub together. The flank will also be filled with fat. A body condition score of 9 indicates energy intake is in excess of energy requirements.

Table 1. Description of individual body condition

Adapted from Henneke et al. 1983 Equine Vet J. 15(4):372 


\section{DETERMINING THE HORSE'S WEIGHT}

To determine a horse's approximate weight:

- use a measuring tape to find the girth or circumference of his barrel and his length

- calculate his weight by using the following formula developed by Carroll and Huntington (1988)

$\mathrm{kg}$ of body weight $=[$ heart girth $(\mathrm{cm}) \times$ heart girth $(\mathrm{cm}) \times$ length $(\mathrm{cm})] / 11,880$

Figure 2 shows how to measure a horse's weight:

- the heart girth measurement should be taken behind the withers and elbows, exactly where the cinch or girth is placed

- body length should be measured from the point of the shoulder to the point of the buttocks (diagram of body parts of the horse)

One can also use a horse-weight tape when convenient. The horse-weight tape can be put around the heart girth of the horse, and the units on the tape are the estimated weight of the horse based on the girth measurement.

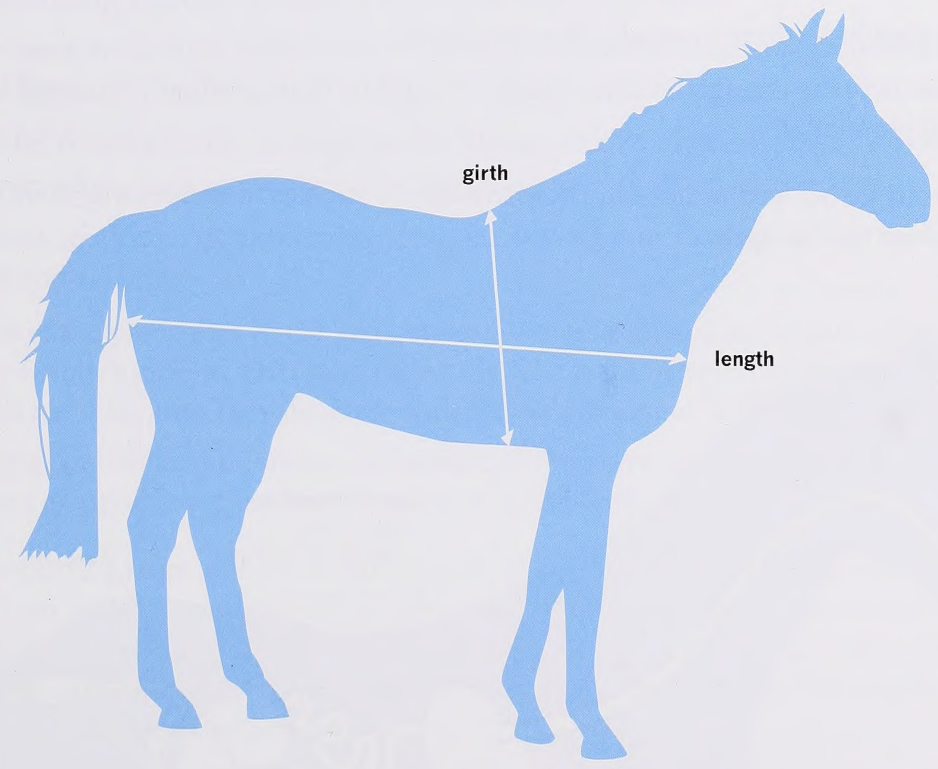

Figure 2. Measuring the horse's heart girth and length. 


\section{DIGESTIVE PHYSIOLOGY}

The digestive tract of the horse is unique. An understanding of it will help explain how the horse is adapted to eating particular feeds.

Figure 3 represents the horse's digestive system. The horse is classified as a non-ruminant herbivore. More specifically, the horse is considered a hindgut fermenter; it is able to digest feeds somewhere between a simple stomached animal (i.e. swine) and a ruminant (i.e. cattle).

Being a hindgut fermenter also means the horse has a specially adapted large intestine containing a large population of microbes that will convert or "ferment" cellulose or fibre into energy for the horse. The microbes have an enzyme called cellulose that is responsible for the breakdown of fibre in hays and fresh forage.

The cellulase enzyme is not produced in mammals. As such, horses have a limited capacity to digest fibre unless a portion of their digestive tract is adapted to maintain a microbial population.

This specially adapted hindgut is unique to the Equidea family and is important for optimal digestion. As such:

- roughages should form the basis of the horse's diet

- feeding should be done in small, frequent meals

- if the diet is being changed, these changes should be done gradually so as not to upset the bacterial population

Horses will easily go off feed or not eat. Digestive upsets such as diarrhoea and colic may occur if changes are made too abruptly.

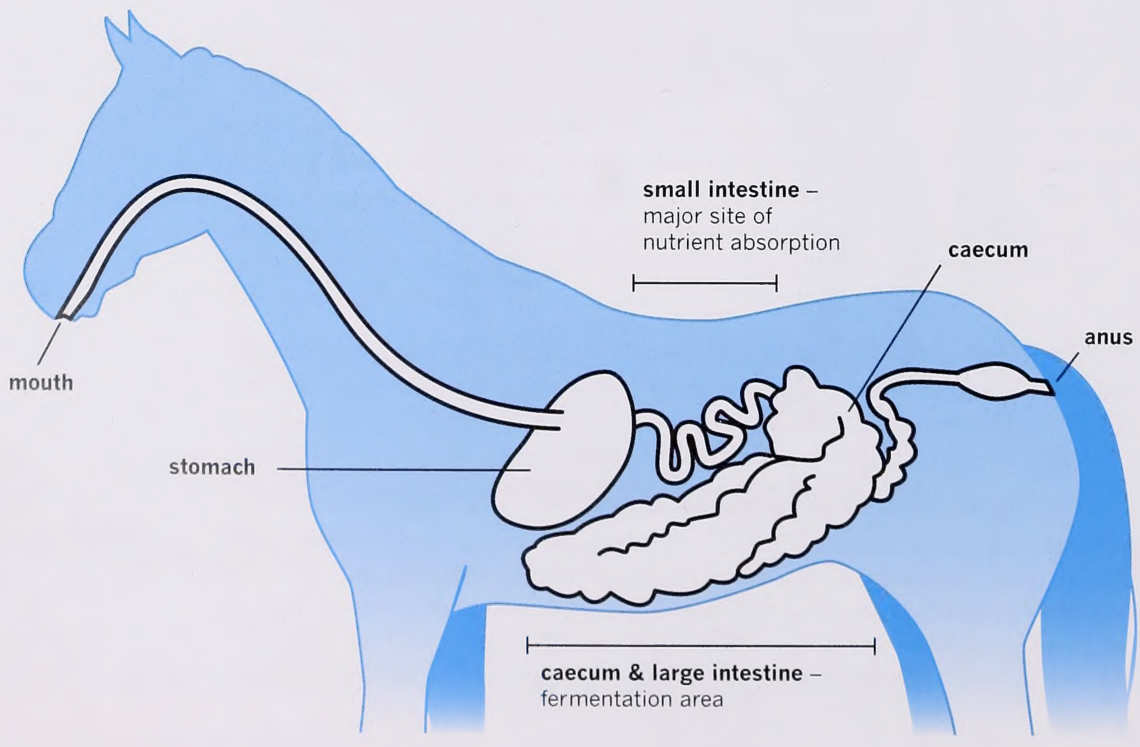




\section{MOUTH}

The lips, tongue and teeth are integral to the selection and prehension (grasping) of feed.

The upper lip is strong and the horse uses it to select food and place it in the mouth. The tongue acts to move the food to the cheek teeth, which then grind the feed down. Feed is broken into tiny pieces (millimetre sized) in order to properly start the digestive process. This means that the teeth should be in good condition and free of any sharp surfaces.

Some horses do not wear their premolars and molars evenly, resulting in injuries to the horse's mouth and a decreased desire to eat and properly chew their food. If horses are losing feed, especially grain, from their mouths when eating, it is possible that dental problems are present. Aged horses often have badly worn teeth and may benefit from feed processing. Between the ages of two and five years, horses should have their teeth examined annually by a veterinarian to prevent future teeth problems, and after five years of age should have teeth examined as necessary.

Horses have two sets of teeth: the deciduous or baby teeth that erupt early in life, and the permanent teeth that replace them. Figure 4 is a diagram of the horse's mouth. The permanent incisors, premolars and molars are ever-growing teeth that continue to erupt to compensate for wear. Their changing form allows one to assess the age of the horse.

- The incisors are located at the front of the horse's mouth; there are six located on both the top and bottom.

- Generally, there is then a long gap in the horse's mouth where the bit of a bridle sits. However, within this gap male horses may have a set of small canine teeth.

- The cheek teeth consist of the premolars (six bottom and six top) and the molars (six bottom and six top).

- In front of the premolars in the gap between the incisors and premolars, there may be two extra premolars (one on each side) called the wolf teeth. A veterinarian commonly removes the wolf teeth because they interfere with the bit placement in the mouth.

- The upper premolars and molars sit outside of the lower premolars and molars, allowing a sideways or circular movement of the jaw to grind feed.

The horse produces a large amount of saliva (over 20 litres per day). Together with tiny chewed up pieces of feed, saliva is swallowed and travels down the esophagus to the stomach. More saliva will be produced in conjunction with hay feeding, and the more watery hay-saliva mixture will allow the hay to pass faster through the stomach and small intestine into the large intestine, where the bulk of digestion occurs. 


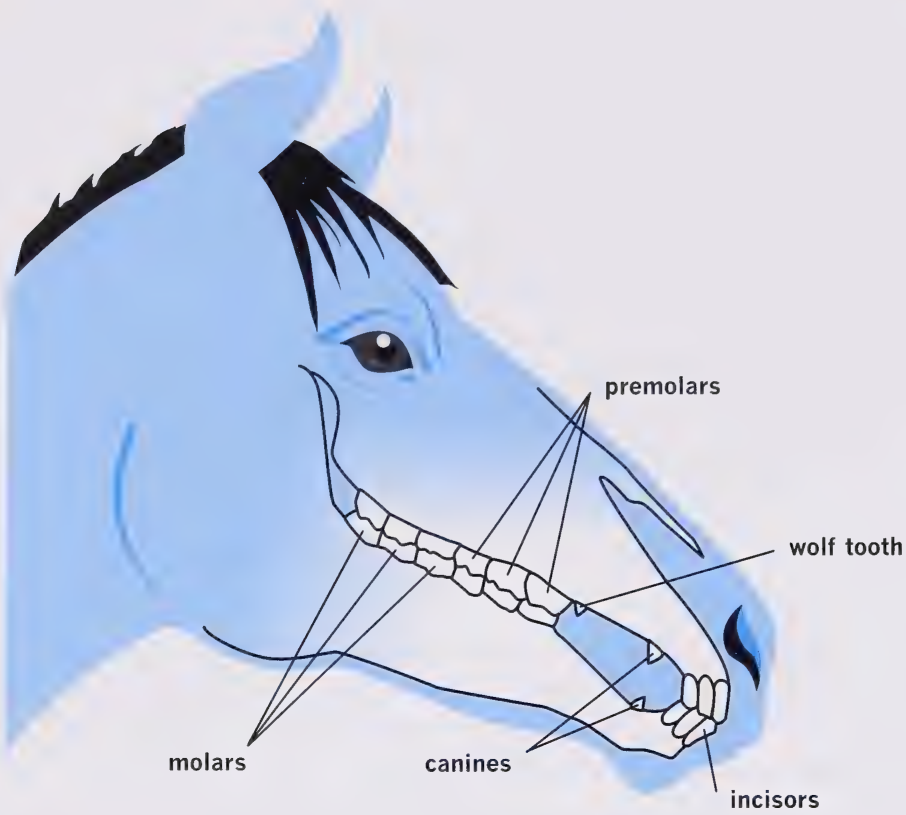

Figure 4. The horse's teeth

\section{PHARYNX}

The pharynx is located at the rear of the mouth before the esophagus. Once food has passed into the pharynx, it cannot return to the mouth.

Unlike many other mammalian species, the horse cannot breathe through its mouth.

\section{ESOPHAGUS}

The esophagus is a long, muscular tube that connects the mouth to the stomach. Food passes through the esophagus by rhythmic or peristaltic muscular contractions. Saliva acts to lubricate the food and prevent it from becoming lodged in the horse's esophagus.

Although "choke," or food becoming lodged in a horse's esophagus, is often discussed, it is a rare occurrence in the horse. Choke can be avoided by changing feeding management and the form of feed offered (i.e. cubes instead of pellets).

\section{STOMACH}

The cardiac sphincter is a valve that regulates the entrance to the stomach. Because the horse eats small frequent meals, the cardiac sphincter functions to constantly push food down into the stomach. In contrast to other species, the cardiac sphincter in the horse is quite strong and does not allow the horse to vomit. This has potentially significant consequences as a mild digestive upset can rapidly become serious colic. 
On the rare occasion when the horse must vomit, vomit will come through the nostrils because of the long soft palate of the horse. This situation may be the result of a ruptured stomach and requires immediate veterinary attention.

The capacity of the horse's stomach is relatively small in comparison to other species, The stomach comprises approximately 10 per cent of the adult horse's digestive system (in contrast to 30 per cent capacity in pigs and 70 per cent capacity in cattle).

The stomach comprises a much larger proportion of the foal gastrointestinal tract during the period when the diet is predominantly milk and grain. The foal's large intestine will grow and develop with the addition of fibre to its diet.

Because the horse has evolved as a continuous grazer, the stomach does not require a great amount of storage space for food. Food remains in the stomach for a short period of time; in most cases between one and six hours, with grains being retained longer than forages. The large amount of water associated with a forage meal will push the stomach contents into the small intestine much faster.

The stomach constantly secretes hydrochloric acid and pepsin, both of which start protein digestion. These are commonly referred to as the gastric juices. A horse will secrete 10-30 litres of gastric juices per day. Although there may be some fermentation of carbohydrates in the stomach by bacteria, there is very little digestion of hay or grain (simple and complex carbohydrates) in the stomach. The digesta from the stomach passes through the pyloric sphincter into the small intestine.

\section{Gastric Ulceration}

The environment in the stomach is highly acidic. Ulcers may result from damage to the stomach lining by highly acidic conditions.

- the occurrence of ulcers is higher in racehorses due to consumption of high grain diets and athletic stress

- stress and use of non-steroidal anti-inflammatory drugs, such as phenylbutasone, increase the risk of ulcers

- saliva production helps to "buffer" the stomach contents and protect the stomach lining from exposure to acids

- feeding diets higher in hay will increase saliva production and lower the occurrence of gastric lesions

- horses that are suffering from gastric lesions will commonly grind their teeth and may colic

\section{General Feeding Tips: Stomach}

Because the capacity of the stomach is very small in contrast to the remainder of the gastrointestinal tract, horses are meant to eat and be fed frequent small meals.

Generally, horses should be fed forages as their primary feedstuff, with additional grain only in the case of highly active horses, young horses, lactating and pregnant mares and older horses. 
If grain is fed as a supplement, it may need to be separated into two or more feedings per day with no more than five pounds of grain per feeding.

Because the cardiac sphincter is so strong, horses cannot vomit and thus are very sensitive to substances that cause digestive upsets, such as mouldy feed.

\section{THE SMALL INTESTINE}

Digesta enters the small intestine from the stomach through the pyloric sphincter.

The small intestine is approximately 20-25 metres in length and comprises approximately 30 per cent of the volume of the gastrointestinal tract. It is the primary site of digestion for fats, proteins and simple carbohydrates such as starches and sugars primarily found in grains. The majority of vitamins and calcium are also absorbed in the small intestine.

The cellulose, or fibre, and phosphorus pass through the small intestine into the large intestine. Fibrous feeds pass relatively rapidly through the small intestine due to the large amount of water and saliva associated with them, but will stay for a longer period of time in the large intestine where they are digested and absorbed.

Grain meals will stay in the small intestine for a longer period of time, as that is the primary site of digestion and absorption for these feeds.

\section{Timing of Grain and Hay Meals: Is There an Advantage?}

Does mixing grain and hay meals cause problems? If fibre passes quickly into the large intestine, and high starch meals pass slowly, how should hay and grain be fed to optimize digestion of both starches and fibre?

There are two popular beliefs to the timing of feeding of hay and grain:

- If hay and grain are fed at the same time, the grain will slow down the passage of hay and optimize digestion.

- If hay is fed with grain, some grain will be pushed along with the hay into the large intestine causing poor digestion of the grain and digestive upsets.

In truth, the timing of hay and grain meals does not make a difference to the average horse that is being fed less than five pounds of grain at a time; they can easily be fed together.

For the high performance horse such as a racehorse that requires a substantial amount of grain or concentrate, digestion may improve and digestive upsets may be minimized if the hay and grain meals are fed separately. The hay should be fed and followed by grain after an hour has passed. Afterwards, there should be a window of three hours between the grain and hay meals to let the grain meal "optimally" digest (Figure 5). 


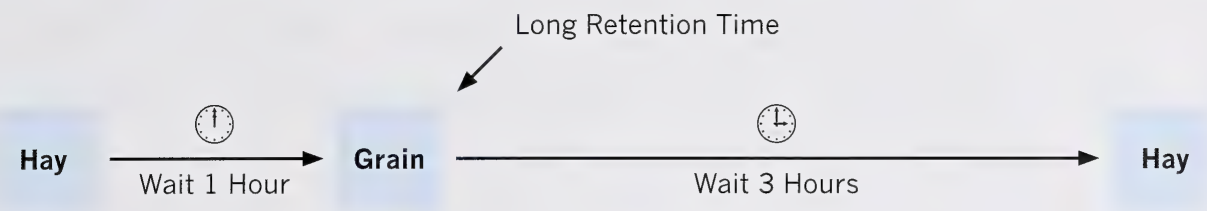

Figure 5. Timing of hay and grain meals. Note: only applies to horses consuming a substantial amount of grain.

\section{LARGE INTESTINE}

The large intestine consists of the cecum, colon, rectum and anus. The large intestine continues to grow throughout the life of a horse due to the highly fibrous diet that the horse typically receives.

\section{Cecum}

The digesta exits the small intestine via the ileo-caecal valve and ends up in the cecum, with a small fraction of digesta entering directly into the colon. The cecum is a large pouch that is the equivalent to the appendix of humans. The cecum is approximately 1.2 metres long and comprises approximately 16 per cent of the capacity of the gastrointestinal tract, or 25-35 litres.

\section{Colon}

The colon is a long tube which comprises approximately 45 per cent of the capacity of the entire gastrointestinal tract, or $>100$ litres of volume. It is approximately three to eight metres in length.

\section{Function of the Cecum and Colon}

Both the cecum and colon house millions of micro-organisms. These micro-organisms are responsible for degrading fibre (cellulose) by fermentation and releasing end products that the horse can use for energy. They are able to ferment cellulose because they have an enzyme called cellulase, which all mammals lack.

The horse's hindgut is very large and houses these micro-organisms to allow it to obtain energy from fibre. The end products of the fermentation of cellulose are called volatile fatty acids (VFA); these are rapidly absorbed in the large intestine. Volatile fatty acids can provide up to 75 per cent of the horse's energy requirements. Starch (primarily from grains) that has escaped absorption in the small intestine will be fermented in the large intestine, producing lactic acid.

The bacteria that reside in the cecum and colon also produce B vitamins and vitamin K. Foals, horses on antibiotics or horses without feed for long periods of time will have reduced bacterial populations in their large intestine and may require another source of the B vitamins.

The diet of the horse can alter the size and bacterial population of the large intestine. Horses that receive higher proportions of grain than forage tend to have a smaller cecum and colon because they digest less fibre than horses eating primarily forages. In this case, these horses may require vitamin B supplements. 
Alternatively, horses that eat a lot of low quality feedstuffs may develop a larger cecum and colon, which will subsequently cause an increase in their abdominal size (hay belly) due to the increased time that digesta spends in the cecum and colon. This enlarged abdomen may result in decreased athletic performance but can be easily remedied with improved nutrition and exercise.

Horses have a very functional large intestine and the bacteria that reside in the intestine provide the horse with much of its energy and vitamins. It is thus important to "feed the bugs" to maintain a healthy digestive tract for the horse. This is done by:

- frequent feeding

- maximizing forages (in the form of hay or pasture) in the diet when possible

- incorporating feed changes gradually into the diet

The rule of thumb is that horses require a minimum of one per cent of their body weight a day in forage.

Horses are not able to utilize low quality forages to supply nutrient needs as readily as cattle: therefore, straw and low quality hay have very limited value as feed for horses. Low quality forages should only be used if the horse's diet already meets his nutritional requirements and he requires additional feed to occupy his time and reduce boredom.

\section{Rectum and Anus}

The rectum is approximately $30 \mathrm{~cm}$ in length and passes through the pelvic girdle and ends in the anus. The rectum and anus are the termination of the gastrointestinal tract. 


\section{NUTRIENTS AND THEIR FUNCTIONS}

Nutrients that can be found in feedstuffs include:

- water

- protein

- carbohydrates

- fats

- minerals

- vitamins

A horse needs energy, which is supplied by carbohydrates and fats, protein, and the appropriate amounts of minerals and vitamins in the diet. The right combination of feedstuffs will provide the required amounts of energy, protein, minerals and vitamins for the horse.

\section{WATER}

The body of the horse is mainly composed of water, and water is important to maintain body temperature and proper body function. Horses will consume three to eight times more water than dry matter (i.e. three $\mathrm{kg}$ of water for every $\mathrm{kg}$ of feed) and will die faster from a lack of water than from lack of any other nutrient.

The horse gets water from two main sources: fresh water and feed. Dried forage (hays and grains) usually contains $10-20$ per cent water, whereas fresh pasture and silage contain substantially more water than hays. Water intake will increase with increased protein intake and higher hay intake. Also, water intakes are higher in growing foals, pregnant and lactating mares, exercising horses and during warm weather.

Restricted water intake can reduce performance, growth and feed intake. Horses will reduce their voluntary water intake if the water is high in total dissolved solids such as salts, or if it is contaminated. Furthermore, water that has a high bacterial or algae content can be a risk to the health of the horse.

Although there are many sources of water, horses should always be provided with a source of potable water.

Generally, the provision of snow as the sole water source in the winter is not sufficient to meet water requirements. If the environmental temperature is below $0^{\circ} \mathrm{C}$ and the water supply is frozen, the ice should be broken at least three times a day to allow the horse to drink. This is especially important because at lower environmental temperatures horses will also likely be eating more feed to produce more body heat.

Water buckets should be emptied and cleaned often to keep the water source as clean as possible especially in the case of growing horses, pregnant and lactating mares and heavily worked horses. Automatic waterers should also be emptied and cleaned frequently and should be checked daily to make sure that they refill. 


\section{WATER QUALITY}

The horse's drinking water, whether from a well, cistern, dug out, pond or stream, should be analyzed regularly.

A water analysis can be obtained through many feed mills and county agricultural fieldmen. This includes:

- $\mathrm{pH}$

- electrical conductivity

- nitrates

- nitrites

- nitrogen

- $\operatorname{potassium}(\mathrm{K})$

- sulfates

- sulphur

- $\operatorname{sodium}(\mathrm{Na})$

- $\operatorname{calcium}(\mathrm{Ca})$

- magnesium (Mg)

- hardness

- total dissolved solids (TDS)

In addition to the above, an extended water analysis includes the following:

- $\operatorname{zinc}(\mathrm{Zn})$

- copper $(\mathrm{Cu})$

- $\operatorname{iron}(\mathrm{Fe})$

- manganese (Mn)

- chlorine $(\mathrm{Cl})$

An additional analysis for total and/or fecal coliforms can also be performed.

\section{Total Dissolved Solids (TDS)}

The best indicator of water quality is the TDS. The TDS is the sum of the concentration of all substances dissolved in the water. TDS gives a useful overall indication of the suitability of a given water source for livestock consumption.

Generally, the safe upper limit of TDS for horses is 6,500 ppm (parts per million or $\mathrm{mg} / \mathrm{L}$ ); however, water for horses should ideally be less than 5,000 ppm. A good rule of thumb is to use better constraints on water quality for young horses, pregnant and/or lactating mares and high performance horses as compared to mature, idle horses.

Water below 1,500 ppm TDS is considered to be fresh water and water between 1,500 and 5,000 is considered to be brackish. Water greater than 5,000 ppm TDS is considered to be saline. Most human drinking water is less than 500 ppm TDS, with drinking water often below $200 \mathrm{ppm}$. 
Often "alkalinity" (sum of alkali metals) or "salinity" are applied to fresh water and used in conjunction with TDS. Of the three, TDS is the best analysis to judge the quality of the water. Neither TDS nor salinity are indicators of the "hardness" of the water; hardness of water depends on the presence of carbonates associated with calcium and magnesium.

A general guide to the suitability of water is as follows:

\begin{tabular}{|c|c|}
\hline Al: $1010 \mathrm{mon}$ & 'Ruintility all gate oralefieds on hurst-- \\
\hline $1,000-3,000$ & satisfactory for horses \\
\hline $3,000-5,000$ & $\begin{array}{l}\text { satisfactory for horses; however, horses not accustomed to the water may refuse to } \\
\text { drink and experience diarrhoea }\end{array}$ \\
\hline $5,000-7,000$ & not suitable for pregnant and lactating mares, growing horses or performance horses \\
\hline $7,000-10,000$ & unfit for horses \\
\hline 10,000 & not recommended for horses under any condition \\
\hline
\end{tabular}

Table 2. TDS (ppm) suitability and general effects on horses

Adapted from Alberta Agriculture and Rural Development's factsheet Water Requirements for Livestock (Agdex 400/716-1).

\section{Other Minerals in Water}

In addition to TDS, a water analysis should also include sodium (Na), potassium (K), magnesium $(\mathrm{Mg})$, iron $(\mathrm{Fe})$, chloride $(\mathrm{Cl})$ and sulphate $(\mathrm{S})$. None of these elements are toxic, but high concentrations of them can decrease water palatability and voluntary water intake.

\section{Algae}

In addition to contaminants found in water, water can also contain bacteria and algae. Species of blue-green algae that are found growing in ponds and lakes are poisonous and should be avoided.

Algae will grow in the presence of organic matter (grain, hay, grass, manure etc.) and heat. Algae can be seen on the top of the water, in the water, or may grow on the sides of water troughs and buckets.

Copper sulphate can be added at one ppm to kill algae, but is harmful to aquatic life. Treated water should not be drunk for two to seven days as copper sulphate releases toxins into the water.

\section{Bacteria}

For the most part, the bacteria in a water supply pose a much greater risk to horses than do the above-mentioned contaminants. Infectious diseases can be transmitted through contaminated water.

As a general rule, if the nitrate and phosphorus levels in the water are low, then the water does not contain excessive bacteria. However, high levels of either substance may indicate a bacterial contamination. Common bacterial contaminants are coliforms, salmonella and giardia. Chlorinated water kills most bacteria but other methods may also be used. Before implementing a method of water purification, ensure it will be safe for farm animals. 


\section{Nitrate Poisoning}

Water high in bacterial growth is often also high in nitrates. This is likely a result of surface contamination from runoff (from both manure and fertilizers). Water nitrate levels are generally highest following wet periods of the year and lowest during dry periods of the year.

Nitrate poisoning usually results from eating feeds with high nitrate levels, and not from drinking water, although the combination does pose risks. Nitrate poisoning is not common in the horse and horses can tolerate high nitrate levels in feeds. Nitrate poisoning of horses through water is rare.

Nitrates in water (or feed) can be converted into nitrites in the horse, which if absorbed into the bloodstream, cause haemoglobin to be unable to bind oxygen. Respiratory difficulties result and may lead to death. High nitrates may also impair iodine metabolism in pregnant mares, so ensure that high nitrates (greater than one per cent of the diet) are not present in feed or water of pregnant mares, and that the horse has a source of iodine.

Although horses can tolerate high nitrate levels better than cattle, nitrates contribute significantly to TDS levels, which is not favourable. Have an analysis done if concerned with the nitrate levels in feed or water.

\section{Other Water Characteristics}

Other physical criteria that can be considered are odour, colour and temperature:

The odour of water is affected by the amount of sulphates, tannins, manure or rotting vegetation and increased levels of these can affect palatability.

Colour is due to the pigmentation of suspended particles within the water and does not affect the usability of the water.

Temperature can affect palatability. Horses generally prefer temperatures between 2 and $10^{\circ} \mathrm{C}$. Warm water promotes the growth of bacteria and certain algae, while horses will decrease their water intake if the water is too cold.

Generally, the following guidelines for water consumption can be followed:

$\begin{array}{llll} & & & \\ 410 \mathrm{~kg} & 13.5 \mathrm{~L}(3 \mathrm{gal}) & 20.0 \mathrm{~L}(4.5 \text { gal }) & 27.0 \mathrm{~L}(6 \text { gal }) \\ 545 \mathrm{~kg} & 18.0 \mathrm{~L}(4 \mathrm{gal}) & 27.0 \mathrm{~L}(6 \text { gal }) & 36.0 \mathrm{~L}(8 \mathrm{gal}) \\ 680 \mathrm{~kg} & 22.5 \mathrm{~L}(5 \mathrm{gal}) & 36.0 \mathrm{~L}(8 \text { gal }) & 45.0 \mathrm{~L}(10 \text { gal }) \\ 820 \mathrm{~kg} & 27.0 \mathrm{~L}(6 \text { gal }) & 43.0 \mathrm{~L}(9.5 \text { gal }) & 54.0 \mathrm{~L}(12 \text { gal })\end{array}$

Table 3. Water requirements

Taken from the Recommended Code of Practice for Horses. Canadian Council on Animal Care (1998). 


\section{WATER AND ELECTROLYTE CONSIDERATIONS FOR ACTIVE HORSES}

Exercise generates a great deal of heat that needs to be eliminated. Horses are very athletic animals partially due to their ability to dissipate heat quickly through sweat. However, sweating can also lead to water and electrolyte losses (sodium, potassium, and chloride).

Water losses due to sweating will result in a reduction in blood volume and should make the horse thirsty; however, thirstiness may be delayed during exercise. Water losses that exceed two per cent of body weight can cause a significant loss of endurance and performance.

In addition to water losses, electrolyte losses can result in several metabolic disturbances that can impair neuromuscular function and overall metabolism. This can result in muscle cramping, tying up, synchronous diaphragmatic flutters (“thumps") and alkalosis. Ultimately, large water and electrolyte losses may mean that the horse stops sweating and cannot dissipate heat. This may lead to a dangerous increase in body temperature.

Horses should be offered water during continued strenuous exercise such as when in an endurance race. If electrolyte mixtures are added to the water, ensure that the horse has previously accepted the mixture.

\section{GENERAL TIPS: WATER}

- A horse will consume approximately 20 litres (6 gal) of water daily. Pregnant and lactating mares and growing foals require more water. Horses require at least three litres of water for every one kg of feed consumed. Restricting water will reduce feed intake, growth rates of young horses, milk production, and can reduce performance.

- Provide the horse with a supply of potable water at all times by keeping buckets and waterers clean, and ensuring that automatic waterers are functioning properly. Pregnant and lactating mares and growing horses may be more sensitive to poor quality water or water restriction.

- In the winter, adequate water intake is even more important due to an increased intake of fibrous feeds.

- Provide exercising horses with water during training sessions and consider adding an electrolyte mixture to the water during strenuous exercise.

- If possible, have the water supply analyzed if concerned about water quality. 


\section{ENERGY}

Energy in the diet is provided through carbohydrates, fats and protein. Next to water, energy is the most important nutrient for:

- maintaining body temperature

- growth

- milk production

- normal body functioning and activity

If the horse does not receive adequate energy through its diet, it will lose weight. Conversely, excess energy will result in weight gain and may cause complications such as metabolic problems and laminitis.

The energy values of horse feeds are given as megacalories of digestible energy per kilogram of feed (Mcal DE $/ \mathrm{kg}$ ). The horse's energy requirements are expressed as the amount of megacalories of digestible energy per day (Mcal DE/day).

\section{Other important information:}

- A calorie is a measure of the amount of heat (energy) required to raise one $g$ of water by one ${ }^{\circ} \mathrm{C}$. The calorie is considered to be the "standard calorie," but the smallest calorie used in nutrition is the kilocalorie ( $\mathrm{kcal}$ ), which is equal to 1,000 calories. The Mcal is equal to $1,000 \mathrm{kcal}$ or 1,000,000 calories; this is the commonly used unit of measure for energy in horse nutrition.

- Total digestible nutrients (TDN) often replaces Mcal and these units are used interchangeably. TDN is a measure of DE expressed in units of weight or as a percentage, where $1 \mathrm{lb} \mathrm{TDN}=2.0 \mathrm{Mcal}$ or $1 \mathrm{~kg}=4.4 \mathrm{Mcal}$ ). TDN is the sum of the weight of digestible carbohydrates, plus protein, plus 2.25 times fats. Today, TDN is rarely used in horse nutrition.

- Each gram of both carbohydrate and protein provide approximately the same amount of energy, while fat provides approximately 2.25 times more energy per gram.

- Net energy (NE) is the most accurate calculation of energy, followed by metabolizable energy (ME) and last by digestible energy (DE). However, the most accurate methods are also the most difficult to determine, and as a result, NE and ME are rarely used for most horse feeds (Figure 6).

- DE values are available for most horse feeds and, as a general rule of thumb, the DE values for forages are approximately 15 per cent lower for horses than for cattle because horses are less efficient at fibre utilization than cattle. The $\mathrm{DE}$ value of forage for cattle can be converted to a $\mathrm{DE}$ value for horses by multiplying by a 0.85 correction factor.

- One kilogram of feed is $2.2 \mathrm{lbs}$ or $1,000 \mathrm{~g}$. 


\section{TYPES OF ENERGY}

\section{Gross energy (GE)}

The heat produced by complete combustion (oxidation) of feed.

$\downarrow$

Digestible energy (DE)

The energy remaining after the energy lost

in the feces is accounted for.

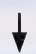

\section{Metabolizable energy (ME)}

The energy remaining after the energy lost in urine and as gases is accounted for.

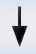

\section{Net energy (NE)}

The energy remaining after digestion of feed has taken place.

NE for maintenance

Energy required for maintenance of life and warmth.

\section{NE for production}

The energy required for production, such as growth, lactation, reproduction and physical performance.

Figure 6. Flowchart of energy determination

\section{Carbohydrates}

There are two major kinds of carbohydrates:

- simple, or non-structural carbohydrates

- complex, or structural carbohydrates

The non-structural carbohydrates are predominantly found in plants in the form of starch and are digested and absorbed as glucose mainly in the small intestine. These are also called nitrogen free extract (NFE) on feed labels.

For horses, the majority of energy in the diet is provided from structural carbohydrates in the form of fibre or cellulose. These carbohydrates comprise the structural part of the plant. These structural carbohydrates are broken down by the action of microbial fermentation in the large intestine to produce volatile fatty acids (VFAs), the major source of energy for the horse. 
Fat

Some fat is important in the horse's diet, as are the essential omega- 3 and omega- 6 fatty acids.

Grains and forages naturally contain some fat, but extra fat can be added to the horse's diet by feeding vegetable oil. In addition, fat is easily digested and utilized well by the horse, making it a good alternative for horses that need to put on weight, or for older horses.

Fat is a more concentrated energy source than grain; therefore, for working horses oil can be supplemented, or replace some grain to provide a good source of energy. One cup of oil can replace $0.7 \mathrm{~kg}(1.5 \mathrm{lbs})$ of grain.

Although research has shown that horses can handle up to 20 per cent of their ration as fat, the current recommendation is to limit the fat content of the daily ration to 10 per cent of the diet or less (two cups of oil). Performance horses that are fed a high fat diet generally have a shinier hair coat and improved behaviour (compared to horses fed a traditional hay/grain diet). High fat diets may benefit horses with recurrent exertional rhabdomyolysis (tying up).

\section{Omega-3 and Omega-6 Fatty Acids}

Omega-3 fatty acids, and the feeding of a lower ratio of omega- 6 fatty acids to omega-3 fatty acids, have recently gained attention in the equine industry.

In general, oil supplementation will help with the intake of these essential fatty acids. Fish oils are exceptionally high in omega- 3 fatty acids, which may aid in improving immune function, in reducing inflammation, and helping with joint disease. However, they are not very palatable for the horse.

The plant source of omega-3 fatty acids is alpha-linolenic acid. The best sources for this are:

- canola oil (11 per cent)

- linseed/flaxseed oils (eight per cent)

Neither corn (one per cent) nor sunflower oil (one per cent) are high in omega-3 fatty acids.

Milled flaxseed is also a good alternative to oils. However, because it is ground, it will spoil more rapidly than whole flaxseed. Fresh pasture, as compared to dried hay or grain, also contains a large amount of omega-3 fatty acids. Other sources of fats would be rice bran and soybeans.

If large amounts of polyunsaturated fats (plant oils) are being fed to the horse, ensure that the horse has adequate amounts of the antioxidant vitamin $\mathrm{E}$ in its diet.

\section{ENERGY SOURCES}

Although fat or oil is the most concentrated source of energy (double that of carbohydrates), grains and concentrates are considered to be rich sources of digestible energy in the form of starches. Table 4 and Appendix 1 show typical values for Alberta feedstuffs.

Roughages containing high fibre, such as fruit and beet pulps, contain an intermediate amount of energy. Alfalfa hay or cubes tend to be more digestible and provide more energy than grass hays; therefore, horses prone to laminitis (founder), or to being overweight may need to be limitfed alfalfa pasture, hay or cubes. 
An accurate estimate of the DE content of hays can be provided by a laboratory for a nominal cost so that hay can be fed at the recommended levels.

\begin{tabular}{lc}
\hline Alfalfa hay & 2.45 \\
Mixed (alfalfa/grass) hay & 2.39 \\
Brome hay & 2.03 \\
Timothy hay & 1.93 \\
Native grass & 1.92 \\
Orchardgrass hay & 2.28 \\
Oat hay (greenfeed) & 2.06 \\
Whole oats & 3.4 \\
Hulless oats & 4.1 \\
Barley & 3.7 \\
Corn & 3.9 \\
Wheat & 3.9 \\
Beet pulp & 2.6 \\
Wheat bran & 3.3 \\
Rice bran & 2.9 \\
Canola oil & 7.2 \\
Soybean meal & 3.5 \\
Canola meal & 3.5 \\
\hline
\end{tabular}

Table 4. Typical digestible energy (DE) content for Alberta feedstuffs. Values are given on a 100 per cent dry matter basis.

\section{FEED ANALYSIS FOR HORSES: DIGESTIBLE ENERGY}

A feed analysis will include a value for digestible energy (DE) in Mcal/kg.

Most labs calculate DE from the acid detergent fibre (ADF) content of the hay based on formulas developed for cattle. This is not accurate for horses because horses do not digest fibre as well as cattle.

The lab will usually return a DE value for the forage based on a formula for cattle. The value has to be adjusted by 85 per cent to obtain a good estimate of the DE in the feed for horses. Therefore, if the lab returns the value of $2.4 \mathrm{Mcal} / \mathrm{kg}$ for hay, multiply that by a correction factor of 0.85 (85 per cent) to get a value of $2.04 \mathrm{Mcal} / \mathrm{kg} \mathrm{DE}$ for the hay. 


\section{ENERGY REOUIREMENTS}

Numerous factors can affect energy requirements of the horse. These include:

- environmental conditions

- age and rate of growth

- body weight

- physiological stage (pregnancy and lactation)

- activity

Poor health will also affect the energy requirements of a horse but will not be discussed within the context of this publication.

The factors listed above are a good guide for estimating energy requirements. However, an assessment of body condition score will determine if the horse is receiving enough energy.

There have been numerous calculations proposed to determine the energy requirements of horses. This publication uses the values from the National Research Council's Nutrient Requirements of Horses (2007). Tables showing the DE requirements for horses of different physiological states for specific mature weights are listed in Appendix 2. The formulas that these tables are based on are described in detail below for each physiological state.

\section{Maintenance}

The amount of digestible energy (DE) needed for maintenance (mature horses, no weight change, relatively idle, non-producing and at moderate environmental conditions) can be calculated by the equation:

DE requirement/day (kcal/day)

- $33.3 \mathrm{kcal} / \mathrm{kg} \times \mathrm{BW}$

- NOTE: $1000 \mathrm{kcal}=1 \mathrm{Mcal}, \mathrm{BW}=$ horse body weight in kilograms

For a $500 \mathrm{~kg}$ horse this would result in a daily digestible energy requirement of $16.7 \mathrm{Mcal}$ per day.

The National Research Council's Nutrient Requirements of Horses (2007) has three different levels of energy for maintenance horses based on minimum, average and elevated maintenance requirements which take into account activity level. As such, if you are feeding an easy keeper, you would feed closer to the minimum level and a hard keeper would require more energy to maintain his body weight.

Therefore, DE requirement/day (kcal/day)

- minimum: $30.3 \mathrm{kcal} / \mathrm{kg} \times \mathrm{BW}$

- average: $33.3 \mathrm{kcal} / \mathrm{kg} \times \mathrm{BW}$

- elevated: $36.3 \mathrm{kcal} / \mathrm{kg} \times \mathrm{BW}$

\section{Working or Exercising Horses}

Estimates of digestible energy requirements for exercise vary widely due to the numerous factors affecting energy output during exercise. 
For example, the energy output during exercise depends on how much weight is carried and the distance that is traveled. However, this estimate increases with the decreasing ability of the rider and the physical condition of the horse. Many other factors may play into the energy output of the horse and are difficult to account for within the scope of a simple equation.

Regular body condition scoring is the best indicator that the horse is receiving adequate energy. For ponies and light horses, there is a $1.2 \times, 1.4 \times$ and $1.9 \times$ correction factor over average maintenance requirements for light, medium and intense work, respectively.

- light work may include pleasure riding, halter, hacking or trail riding, hunter riding and equitation

- medium work may include pole bending, barrel racing, cutting, roping and jumping

- heavy work includes racing, polo and endurance riding

DE Requirement/Day

- light work (Mcal/day) $=1.2 \times(0.0333 \times \mathrm{BW})$

- medium work (Mcal/day) $=1.4 \times(0.0333 \times$ BW $)$

- heavy work (Mcal/day) $=1.9 \times(0.0333 \times$ BW $)$

- NOTE: BW = body weight in kilograms

For draft horses, energy needs depend most heavily upon how much weight is being pulled and the type of work performed. Adding an additional 10 per cent to the energy needs of these horses is likely a reasonable estimate of the increased energy requirements of these horses.

\section{Pregnancy or Lactation}

The greatest amount of foetal growth in pregnant mares occurs in the last three months of gestation. In these last three months, feed intake should increase by $10-20$ per cent above maintenance energy requirements.

In the last three months of pregnancy, it is likely that the mare will require a grain/concentrate supplement for her hay to meet her energy requirements. This is due to the increased size of the fetus limiting feed intake of the mare.

The greatest increase in energy requirements is seen during lactation. Mares require a:

- 70-80 per cent increase in energy requirements over the maintenance requirement during the first three months

- 50 per cent increase after the third month of lactation

\section{Growing Horses}

For young horses, energy needs increase with increasing growth rate and size. However, on a per $\mathrm{kg}$ basis as the horse gets older and bigger, growth rate slows and energy requirements decrease. The formula for growing horses of 4-24 months of age is:

- DE requirements $(\mathrm{Mcal} /$ day $)=\left(0.0565 \mathrm{x}^{-0.145}\right) \mathrm{X} \mathrm{BW}+\left(1.99+1.21 \mathrm{x}-0.021 \mathrm{x}^{2}\right) \mathrm{X}$ ADG

Where $\mathrm{x}$ is the age in months and ADG is average daily gain in $\mathrm{kg} / \mathrm{day}$. 
Young horses should be fed a well-balanced diet that meets the horse's needs for energy, protein, minerals and vitamins. Underfeeding a young horse can reduce its growth rate, but this should not be used in place of a well-balanced diet in order to reduce the incidence of developmental orthopaedic diseases (DOD) (see section on feeding management for growing horses). However, overfeeding young horses by 30 per cent above their energy requirements has resulted in increased incidence of DOD.

\section{ENERGY INTAKE}

The general rule of thumb is to feed a mature, idle horse two per cent of its body weight in dry matter (DM) per day. A horse will need to eat less good quality forage to meet its energy requirements than poor quality forage.

If a horse has increased energy requirements that cannot be met by simply increasing hay intake, the energy density of the diet needs to be increased by feeding a better quality (higher energy density) forage, and/or supplementing grain, concentrates or fat. Average intakes of forages and grains for specific classes of horses are given in Table 5.

\begin{tabular}{|c|c|c|c|}
\hline$(1+5 \times)=$ & 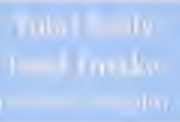 & 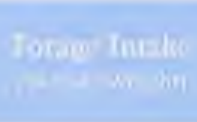 & 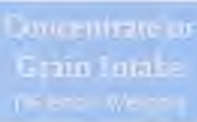 \\
\hline Mature horse & $1.5-2.0$ & $1.5-2.0$ & 0 \\
\hline $\begin{array}{l}\text { - Light work } \\
\text { - Stallion } \\
\text { - } 2 \text {-year old } \\
\text {. } \\
\text { Mare late-gestation }\end{array}$ & $2.0-2.5$ & $1.5-2.5$ & $0-0.5$ \\
\hline $\begin{array}{l}\text { - Medium-heavy work } \\
\text { - Lactating mare }\end{array}$ & $2.0-3.0$ & $1.5-2.0$ & $0.5-1.5$ \\
\hline Weanling & $2.0-3.0$ & $1.0-1.5$ & $1.0-1.5$ \\
\hline
\end{tabular}

Table 5. Average forage and concentrate intakes for various classes of horse.

Adapted from the National Research Council's Nutrient Requirements of Horses (1989).

\section{Inadequate Energy Intake}

The first symptom of inadequate energy intake will be weight loss in a mature horse, or a reduction in growth rate for a young horse.

Energy deficiencies occur most commonly in growing horses during the winter. This occurs because feed intake or feed quality has not been increased during the cold weather. Segregation of horses by size, age, body condition or pecking order may be necessary, in order to separate horses with different energy needs.

\section{Feeding Underfed or Malnourished Horses}

To rule out health-related problems such as illness, parasite infestations, teeth problems or other physical problems, a veterinarian should first examine malnourished, thin and weak horses. These horses should be fed high quality forage with additional grain or concentrate. 
This increase in feed intake should be done slowly. Malnourished horses should be started off with about one third of the projected feed intake for the target body weight and gradually increased over two-to-three weeks to the target intake.

Water and salt should be available to the horse at all times. Salt encourages water consumption, which is directly related to feed consumption. Increased water consumption will help avoid the chance of feed impaction. If diarrhoea, colic, or founder occur, stop increasing feed intake until these conditions improve.

Underfed or malnourished horses should be fed in small frequent meals throughout the day. For a specific feeding program that utilises oats to improve body condition score, see Table 6 .

\begin{tabular}{|c|c|c|c|c|c|}
\hline \multicolumn{3}{|c|}{ 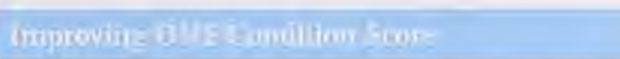 } & \multicolumn{3}{|c|}{ 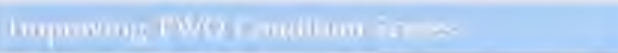 } \\
\hline 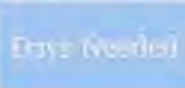 & Bank $\cos$ in & 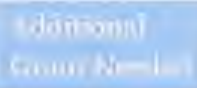 & Wy ke ma & Whingein & 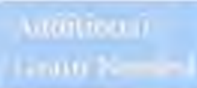 \\
\hline 80 Days & $\begin{array}{l}0.75 \mathrm{lbs} / \text { day } \\
(0.35 \mathrm{~kg} / \text { day })\end{array}$ & $\begin{array}{l}4.5 \mathrm{lbs} / \text { day } \\
\text { (2.0 kg/day) }\end{array}$ & 90 Days & $\begin{array}{l}1.00 \mathrm{lbs} / \text { day } \\
(0.45 \mathrm{~kg} / \text { day })\end{array}$ & $\begin{array}{l}6.0 \mathrm{lbs} / \text { day } \\
\text { (2.8 kg/day) }\end{array}$ \\
\hline 90 Days & $\begin{array}{l}0.50 \mathrm{lbs} / \text { day } \\
(0.22 \mathrm{~kg} / \text { day })\end{array}$ & $\begin{array}{l}3.0 \mathrm{lbs} / \text { day } \\
\text { (1.4 kg/day) }\end{array}$ & 120 Days & $\begin{array}{l}0.75 \mathrm{lbs} / \text { day } \\
(0.35 \mathrm{~kg} / \text { day })\end{array}$ & $\begin{array}{l}4.5 \mathrm{lbs} / \text { day } \\
(2.0 \mathrm{~kg} / \text { day })\end{array}$ \\
\hline 120 Days & $\begin{array}{l}0.40 \mathrm{lbs} / \text { day } \\
(0.2 \mathrm{~kg} / \text { day })\end{array}$ & $\begin{array}{l}2.3 \mathrm{lbs} / \text { day } \\
(1 \mathrm{~kg} / \text { day })\end{array}$ & 150 Days & $\begin{array}{l}0.60 \mathrm{lbs} / \text { day } \\
(0.30 \mathrm{~kg} / \text { day })\end{array}$ & $\begin{array}{l}3.5 \mathrm{lbs} / \text { day } \\
\text { (1.6 kg/day) }\end{array}$ \\
\hline
\end{tabular}

Table 6. Time and additional grain required to improve body condition score by 1 or 2 levels

From Alberta Agriculture and Rural Development's factsheet Feeding the Broodmare (Agdex 460/50-6).

Excess Energy Intake

Horses do not necessarily eat to their energy requirements. A horse will overeat on good quality pasture, hay or grain. They can easily consume three per cent of their body weight on good pasture or excellent hay per day. Excess feed intake or energy will ultimately lead to weight gain.

A chronic excessive energy intake will cause a horse to become obese (body condition score of 8 and higher). Obese horses and horses receiving excess energy are at risk of developing laminitis (founder) and metabolic problems such as insulin resistance.

As a rule of thumb, inactive mature horses become overweight on an average to good quality pasture. This can be managed by limiting grazing time. For example, horses can be grazed oneto-two hours in the morning and evening.

Horses that are lightly worked can become overweight when additional grain/concentrate is added to medium-to-good quality forage that alone would meet the horse's energy requirements. 


\section{GENERAL FEEDING TIPS: ENERGY}

- Feed to maintain an ideal body condition score.

- Have your hay/forage analyzed for nutrient content.

- Energy intake can be increased by increasing feed intake, increasing the quality of forage fed, or by adding grains/concentrates/fats to the diet.

- If the horse does not receive enough energy, weight loss will result. Excess energy intake will cause the horse to gain weight.

- Energy requirements increase between ten to twenty per cent for mares in their last three months of pregnancy. Energy requirements increase by at least 70 per cent for mares in their first three months of lactation.

- Feed growing horses to meet their energy requirements without under or overfeeding energy. Feed a well-balanced diet for energy protein minerals and vitamins to ensure an optimal growth rate.

- Exercising horses can require up to twice the energy (for heavily worked horses such as race horses) than does an idle mature horse.

- In the winter, the energy intake or quality of feed may need to be increased.

- An idle mature horse kept on pasture or good quality hay may become overweight. Restrict pasture access or restrict feed intake to meet energy requirements.

- It may be necessary to segregate horses with different energy needs. 


\section{PROTEIN}

Protein is needed for growth and maintenance of muscles, bone, skin, hair and hooves. Protein is also needed for foetal growth during pregnancy, and milk production in the lactating mare.

Protein is made up of many individual amino acids. There are 20 different amino acids in protein (Table 7). Each of these amino acids is needed by the horse's body to synthesize proteins such as muscle. Many can be made by the horse itself, and these are called non-essential amino acids.

However, there are 10 amino acids that need to be supplied in the horse's diet. These are called essential amino acids.

Feeds that have a high proportion of essential amino acids (generally this will be lysine, tryptophan, threonine and/or methionine) are considered to be high in protein quality (such as soybean meal), whereas feeds containing a low amount of essential amino acids are considered to be poor quality proteins (corn is low in some of the essential amino acids).

Although great advancements have been made in assessing both the digestibility and requirements of protein and amino acids in other agricultural species such as the pig and chicken, there is very little information available for the horse.

\begin{tabular}{ll}
\hline Alanine & Methionine \\
Aspartic acid & Arginine \\
Cysteine & Threonine \\
Glutamic acid & Tryptophan \\
Glycine & Valine \\
Proline & Phenylalanine \\
Serine & Histidine \\
Tyrosine & Isoleuine \\
Asparagine & Leucine \\
Glutamine & Lysine
\end{tabular}

Table 7. Essential and non-essential amino acids. Essential amino acids are required in the horse's diet while non-essential amino acids are not.

\section{PROTEIN SOURCES}

Protein contains approximately 16 per cent nitrogen. The crude protein content of a feedstuff is determined by measuring its nitrogen content and dividing that value by 16 per cent or 0.16 .

For example, a feedstuff containing two per cent nitrogen would contain 12.5 per cent crude protein. The protein content (per cent of crude protein) of typical Alberta feeds is given in Table 8 (see Appendix 2 for a complete listing of nutrient requirements for horses). 
Legumes have a higher per cent of crude protein than do grasses, while cereals have intermediate amounts of protein. Typically, protein supplements are:

- soybean meal

- canola meal

- flax or linseed meal

The per cent value given in commercial feeds, such as 12 per cent sweet feed, is the per cent value of crude protein (CP) the feed contains.

$\begin{array}{lc} & 17.9 \\ \text { Alfalfa hay } & 14.8 \\ \text { Mixed (alfalfa/grass) hay } & 9.6 \\ \text { Brome hay } & 8.3 \\ \text { Timothy hay } & 8.2 \\ \text { Native grass } & 9.4 \\ \text { Oat hay (greenfeed) } & 11.9 \\ \text { Whole oats } & 17.6 \\ \text { Hulless oats } & 12.6 \\ \text { Barley } & 10.3 \\ \text { Corn } & 15.9 \\ \text { Wheat } & 10.0 \\ \text { Beet pulp } & 17.4 \\ \text { Wheat bran } & 14 \\ \text { Rice bran } & 0 \\ \text { Canola oil } & 48.0 \\ \text { Soybean meal } & 35.0 \\ \text { Canola meal } & 36.0 \\ \text { Flax/Linseed meal } & \\ \text { Table } 8 \text { Crude protein content of typical feedstuffs. Soybean and canola meal are typical protein supplements. } \\ \text { Percentages are given on a } 100 \text { per cent dry matter basis. }\end{array}$

\section{PROTEIN REOUIREMENTS}

Protein requirements of horses are typically given as a percentage of dry matter intake (DM) or on a weight basis as grams of crude protein (Table 9 and Appendix 2). In this publication, the requirements for crude protein (CP) are taken from the National Research Council's Nutrient Requirements of Horses (2007).

The concentration in the feedstuff (per cent crude protein) multiplied by the weight of that feedstuff fed will give the absolute weight of crude protein supplied. Protein needs generally increase with increased energy requirements. 


\begin{tabular}{l|l|l|}
\hline & & \\
\hline Maintenance-average & 8.0 & 630 \\
Stallion & 9.6 & 789 \\
Late pregnancy & 10.6 & 841 \\
Early lactation & 13.2 & 1530 \\
Late lactation & 11.0 & 1330 \\
Working horses-light work & 9.8 & 699 \\
Working horses-medium work & 10.4 & 768 \\
Working horses-hard work & 11.4 & 862 \\
Weanling & 14.5 & 669 \\
Yearling & 12.6 & 846 \\
Two-year old & 10.4 & 770
\end{tabular}

Table 9. Protein requirements of horses. More detail is provided in Appendix 2

\section{Maintenance Horse}

A mature, idle horse requires eight per cent CP in its diet, or $630 \mathrm{~g}$ of protein for a $500 \mathrm{~kg}$ horse.

\section{Pregnancy or Lactation}

The protein requirements for non-lactating mares during breeding and early gestation (up to eight months pregnant) are identical the requirements of a horse at maintenance levels. Due to the growth of the fetus, mares in their last three months of pregnancy require approximately 10 per cent CP in the diet or $866 \mathrm{~g}$ for a $500 \mathrm{~kg}$ horse.

In the first three months of lactation, the protein content in the mare's milk and the amount of milk produced will peak in order to support the rapid growth rate of the foal. Because of the tremendous amount of protein deposited in milk (315 g of protein per day) the mare will require a 60-70 per cent increase in her protein intake, increasing the levels to 13 per cent CP in her diet.

As the lactation period progresses, the energy and protein density of the milk decreases gradually and she will require 11 per cent $\mathrm{CP}$ in her diet.

\section{Growing Horses}

During growth, both the amount of protein and its amino acids quality are important.

Diets high in protein do not cause developmental orthopaedic diseases (DOD) in foals, but overfeeding energy can contribute to these problems. A foal's diet should be well balanced and provide energy, protein, minerals and vitamins in the appropriate amounts. Table 10 on page 32 lists the per cent CP of the diet for foals and growing horses. The amount of protein that a weanling foal needs in its diet is more than is supplied by grass hays and cereal grains. 
Often up to one year of age, young horses require a grain-based protein supplement mixture (such as 20 per cent CP) to complement grass hay. Mixed alfalfa-grass hay is also an excellent choice and contains higher protein levels. A commercial foal mixture is often the simplest choice because it is balanced and provides added energy, protein, minerals and vitamins in appropriate amounts.

Growing horses should receive a diet that is high in good quality protein, especially in the amino acids lysine, tryptophan, methionine and threonine. The diet for growing horses should provide at least 0.65 per cent lysine and 0.5 per cent threonine on a dry matter basis.

Feeds with soybean meal or commercial feeds are typically high quality protein feeds. Yearlings are often capable of meeting protein requirements on mixed alfalfa/grass hay, summer pasture, or grass hay and 14-16 per cent commercial feed.

\section{Working Horses}

Although working horses seem able to handle higher protein levels in their diet, exercise has little effect on the protein requirement of horses. The increase in energy requirements for the exercising horse far surpasses the increased need for protein.

To meet energy requirements for the horse:

- feed intake can be increased, which will satisfy the increased protein needs of the horse

- the energy density of the diet can be increased by adding a grain or concentrate

\section{PROTEIN DEFICIENCY}

It is rare to see symptoms of a protein deficiency alone, as most feed for horses provides both energy and protein.

A protein deficiency can be characterized by the following symptoms:

- reduced growth in young horses

- weight loss

- reduced athletic performance

- reduced production (e.g. lower milk production in mares can usually be detected by a lack of growth or reduced growth in the foal, or low foal birth weight for pregnant mares)

Because protein plays an integral role in the everyday growth and/or maintenance of hair, skin and hooves, a protein deficiency will result in these being replaced at a slower rate than usual. When skin and hair are replaced at a slower rate than usual, hair growth and shedding are slowed as well. This results in rough, coarse hair that lacks lustre.

When hooves are replaced at a slower rate, they may begin to crack or split and growth will be reduced.

In addition to these symptoms, horses with a protein deficiency may lose their appetite and start eating feces. 
Protein deficiencies are generally caused by inadequate protein in the diet. This often occurs when poor quality forages or mature grass forages are fed. This usually results in an inadequate feed intake, and will be compounded with an energy deficiency.

When there is inadequate energy provided in the diet, protein will be used for energy production; this too may cause a protein deficiency. Always ensure that the horse's requirements for energy are met, and then ensure that protein needs are met.

\section{PROTEIN EXCESS}

While overfeeding protein usually won't harm a horse, it is a waste of money.

Since protein is not stored like fat in the body, it needs to be broken down. If the horse is fed more protein than it needs, it will use some of its energy to break down the protein into urea, where it is excreted in the urine. As a result, high protein intakes result in:

- higher water consumption

- higher urine output

- increased ammonia smell

Horses that have liver or kidney problems should not be fed high amounts of protein.

\section{OTHER ASPECTS OF FEEDING PROTEIN}

Higher protein feeds such as alfalfa hay are often blamed for causing the horse to be highspirited and for causing founder. This is because higher protein feeds tend to be also high in energy and easily digestible. Take care not to overfeed horses that are prone to being overweight or to foundering, and be especially careful not to overfeed them with higher-protein feeds.

Urea or non-protein nitrogen is often used in cattle diets; however, horses cannot utilize urea as a protein source like cattle can. If urea is a component of the diet, it should not be more than four per cent of the total diet.

Occasionally, allergies to certain protein sources may occur when a new protein source is introduced. If a horse has an allergic reaction to its protein source it may form round elevated areas on the skin surface any place on the body. These are often referred to as protein bumps. They may be present for hours or days before they disappear. 


\section{GENERAL FEEDING TIPS: PROTEIN}

- When assessing the body condition score for your horse, take note of the condition of the hooves and coat.

- Have your hay/forage analyzed for nutrient content to find out the per cent crude protein of your forage. If it does not meet protein requirements, adjust the grain/concentrate portion of the diet with a protein supplement if necessary or feed better quality hay.

- The amount of protein in the diet can be increased by either increasing the percentage of protein (per cent CP) in the diet or by increasing overall feed intake (kg of feed supplied to the horse per day). Increasing the percentage protein generally means adding a good quality protein supplement such as soybean meal, canola meal, (or milk products in a young horse's diet) or by feeding a legume or mixed legume/grass hay instead of grass hay alone.

- If a horse has inadequate feed intake, or is on poor quality forage, both energy and protein will be lacking and the horse will lose weight and condition and likely eat less. Protein deficiency will be characterized by poor hair coat, cracking or splitting of the hooves and weight loss.

- Pregnant and lactating mares have substantially increased protein and energy requirements.

- Growing horses require a diet containing a high quality protein for growth. It is important that a young horse's diet be balanced for both energy and protein to meet requirements without over or underfeeding.

- The needs of working horses for increased energy greatly surpass their protein needs. 


\section{MINERALS FOR HORSES}

Minerals are categorized into macro and micro minerals.

Macrominerals are required in the diet on a percentage $(\mathrm{g} / \mathrm{kg}$ of feed) basis and include:

- $\operatorname{calcium}(\mathrm{Ca})$

- phosphorus (P)

- $\operatorname{sodium}(\mathrm{Na})$

- $\operatorname{potassium}(\mathrm{K})$

- chlorine $(\mathrm{Cl})$

- magnesium (Mg)

- $\operatorname{sulphur}(\mathrm{S})$

Microminerals are required in the diet on a parts-per-million (ppm or $\mathrm{mg} / \mathrm{kg}$ of feed) basis, and include:

- $\operatorname{selenium~(Se)}$

- iodine (I)

- $\operatorname{copper}(\mathrm{Cu})$

- zinc (Zn)

- manganese (Mn)

- $\operatorname{iron}(\mathrm{Fe})$

- $\operatorname{cobalt}(\mathrm{Co})$

Before considering mineral supplementation, it is important to understand the horse's requirements for minerals and how they are obtained through the horse's diet.

The macrominerals are needed in the body for:

- structure (calcium, phosphorus and magnesium in the bones)

- maintenance of the body's acid-base and fluid balance

- nerve conduction

- muscle contraction

The microminerals are needed as components of enzymes that are involved in necessary biochemical reactions in the horse's body (iodine is a component of thyroid hormone).

Of the microminerals, only zinc, copper, selenium and manganese are of concern. These four trace minerals have been shown to be deficient in Alberta hays (see Table 10 and 11). Supplementation of microminerals in the form of trace-mineralized salt or a vitamin/mineral premix would be beneficial. Selenium levels can vary greatly in different soil regions, and has the potential to be quite toxic; therefore, supplementation of selenium should be done with care. 
It is important to remember that when evaluating the mineral content of the total diet, minerals should be regarded as a group rather than individually. Increased intake of individual minerals generally results in increased excretion of these in the urine and/or feces; however, minerals that are not absorbed can bind other minerals, possibly causing deficiencies of other minerals.

The best example of this relationship is the relationship between calcium and phosphorus. Calcium and phosphorus should always be considered together. The optimum ratio of these minerals is two parts calcium to one part phosphorus. If the horse takes in more phosphorus than calcium, it will develop a calcium deficiency.

\begin{tabular}{lllll}
\hline Alfalfa & 6 & 25 & 40 & 0.28 \\
Alfalfa/grass & 6 & 23 & 48 & 0.35 \\
Timothy & 4 & 21 & 48 & 0.11 \\
Native & 5 & 20 & 55 & 0.13 \\
Oat hay & 5 & 23 & 54 & 0.15 \\
Oats & 4 & 33 & 45 & 0.10 \\
\hline
\end{tabular}

Table 10. Micromineral content of Alberta hays.

Values reported on a $100 \%$ dry basis.

Values reported are averages of feeds analyzed by Alberta Agriculture and Rural Development's Soil and Feed Testing Laboratory, Edmonton, Alberta. 1967.1994.

\begin{tabular}{|c|c|c|c|}
\hline 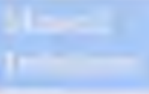 & 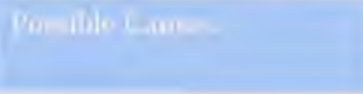 & gycoutionso: & Sis sonvt 2 \\
\hline $\begin{array}{l}\text { Calcium } \\
\text { deficiency }\end{array}$ & $\begin{array}{l}\text { Dietary calcium is not } \\
\text { meeting the requirements } \\
\text { of the horse. } \\
\text { - P is greater than Ca. } \\
\text { - Vitamin D deficiency. }\end{array}$ & $\begin{array}{l}\text { - Growing horses: developmental } \\
\text { orthopaedic diseases (DOD) and low } \\
\text { bone density (rickets). } \\
\text { - All horses: stiff gait, movement } \\
\text { problems, lameness, bone density } \\
\text { problems (osteomalacia) resulting } \\
\text { in fractures. }\end{array}$ & $\begin{array}{l}\text { - Milk. } \\
\text { - Legumes. } \\
\text { - Grasses. } \\
\text { - Hay. } \\
\text { - Beet pulp. }\end{array}$ \\
\hline $\begin{array}{l}\text { Calcium } \\
\text { excess }\end{array}$ & $\begin{array}{l}\text { Ca:P is higher than } 7: 1 \\
\text { (mature horses) or } 3: 1 \\
\text { (growing horses) due to excess } \\
\text { addition of calcium to the diet. }\end{array}$ & $\begin{array}{l}\text { - Growing horses: DOD, poor absorption } \\
\text { of other minerals ( } \mathrm{Zn} \text { and } \mathrm{Mg} \text { ). } \\
\text { - May cause abnormal bone deposition by } \\
\text { excessive calcification. }\end{array}$ & \\
\hline $\begin{array}{l}\text { Phosphorus } \\
\text { deficiency }\end{array}$ & $\begin{array}{l}\text { The phosphorus requirement } \\
\text { (g/day) is not met. }\end{array}$ & $\begin{array}{l}\text { Same as calcium deficiency resulting } \\
\text { in a loss in bone density (osteomalacia } \\
\text { or rickets). }\end{array}$ & $\begin{array}{l}\text { - Wheat bran. } \\
\text { - Rice bran. }\end{array}$ \\
\hline $\begin{array}{l}\text { Phosphorus } \\
\text { excess }\end{array}$ & $\begin{array}{l}\text { Bran is fed in high amounts. } \\
\text { Since bran is particularly } \\
\text { high in } P \text { it will cause a low } \\
\text { Ca:P ratio. }\end{array}$ & $\begin{array}{l}\text { Miller's disease, or big head disease: } \\
\text { enlarged facial bones. }\end{array}$ & \\
\hline
\end{tabular}




\begin{tabular}{|c|c|c|c|}
\hline $\begin{array}{l}\text { Winerdi } \\
\text { Imlminims }\end{array}$ & Pussible Cantsa & Evmplome & Breh Smugse \\
\hline $\begin{array}{l}\text { Sodium } \\
\text { deficiency }\end{array}$ & $\begin{array}{l}\text { - No salt available } \\
\text { (free access). } \\
\text { - No salt in feed or water. }\end{array}$ & $\begin{array}{l}\text { - Acute symptoms: muscle contractions } \\
\text { and horses appear to be unsteady on } \\
\text { their feet. } \\
\text { - Chronic: horses lick sweat contaminated } \\
\text { objects (i.e. leather). } \\
\text { - Feed and water intake reduced }\end{array}$ & $\begin{array}{l}\text { - Loose salt or salt } \\
\text { blocks. } \\
\text { - Commercial } \\
\text { feeds with added } \\
\text { salt. } \\
\text { - Electrolytes. }\end{array}$ \\
\hline $\begin{array}{l}\text { Sodium } \\
\text { excess }\end{array}$ & $\begin{array}{l}\text { Water supply is saline or } \\
\text { high in total dissolved salts. } \\
\text { - Non-saline water is } \\
\text { not provided. }\end{array}$ & $\begin{array}{l}\text { Sodium excess is rare as most horses } \\
\text { will compensate with increased water } \\
\text { intake. } \\
\text { - Clinical signs include diarrhoea, } \\
\text { frequent urination, weakness, colic, and } \\
\text { lack of coordination. }\end{array}$ & $\begin{array}{l}\text { - Fresh non- } \\
\text { saline water. }\end{array}$ \\
\hline $\begin{array}{l}\text { Potassium } \\
\text { deficiency }\end{array}$ & $\begin{array}{l}\text { - Increased physical } \\
\text { output which will causes } \\
\text { increased sweating. } \\
\text { - The use of diuretics. }\end{array}$ & $\begin{array}{l}\text { Fatigue, muscle weakness and decreased } \\
\text { feed and water intake. }\end{array}$ & $\begin{array}{l}\text { - Forages. } \\
\text { - Electrolytes (1/2 } \\
\mathrm{NaCl}, 1 / 2 \mathrm{KCl})\end{array}$ \\
\hline $\begin{array}{l}\text { Potassium } \\
\text { excess }\end{array}$ & $\begin{array}{l}\text { Potassium induced periodic } \\
\text { paralysis (HYPP). }\end{array}$ & $\begin{array}{l}\text { Can be caused by a variety of factors } \\
\text { including a diet change or any stress } \\
\text { (environmental changes, trailering, } \\
\text { and exercise). }\end{array}$ & \\
\hline $\begin{array}{l}\text { Magnesium } \\
\text { deficiency }\end{array}$ & $\begin{array}{l}\text { Diets high in potassium } \\
\text { and low in magnesium. } \\
\text { - Lactation induced. } \\
\text { - Stress induced (transit). }\end{array}$ & $\begin{array}{l}\text { Nervousness, muscle tremors, increased } \\
\text { respiratory rate, sweating. } \\
\text { "Grass tetany" or "milk tetany"; both rare } \\
\text { in horses. }\end{array}$ & $\begin{array}{l}\text { - Forages. } \\
\text { - } \mathrm{Mg} / \mathrm{Ca} \text { injection. }\end{array}$ \\
\hline $\begin{array}{l}\text { Magnesium } \\
\text { excess }\end{array}$ & Does not occur. & & \\
\hline $\begin{array}{l}\text { Selenium } \\
\text { deficiency }\end{array}$ & $\begin{array}{l}\text { In foals, due to insufficient } \\
\text { selenium in the mare's } \\
\text { milk because of inadequate } \\
\text { dietary selenium. } \\
\text { - In adults, low selenium } \\
\text { in the feed due to soil } \\
\text { deficiency or pH. }\end{array}$ & $\begin{array}{l}\text { Mild symptoms: low immune function } \\
\text { and reduced growth. } \\
\text { Clinical symptoms: yellow-fat disease, } \\
\text { degeneration of smooth, cardiac and } \\
\text { skeletal muscle (white muscle disease in } \\
\text { foals), myeloencephalopathy, increased } \\
\text { respiratory and heart rate. }\end{array}$ & $\begin{array}{l}\text { - Mineral } \\
\text { supplements. } \\
\text { - TM salt with } \\
\text { selenium Some } \\
\text { commercial } \\
\text { feeds. }\end{array}$ \\
\hline $\begin{array}{l}\text { Selenium } \\
\text { excess }\end{array}$ & $\begin{array}{l}\text { - Improper dosage of a } \\
\text { selenium/vitamin E } \\
\text { injection. } \\
\text { - Improper supplementation } \\
\text { that results in selenium } \\
\text { levels }>2 \text { ppm. }\end{array}$ & $\begin{array}{l}\text { Blind staggers, weight loss, rough hair } \\
\text { and dandruff and cracking of the hooves } \\
\text { around the coronary band. }\end{array}$ & $\begin{array}{l}\text { - Remove } \\
\text { selenium } \\
\text { supplementation. }\end{array}$ \\
\hline
\end{tabular}




\begin{tabular}{|c|c|c|c|}
\hline 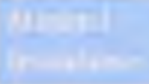 & 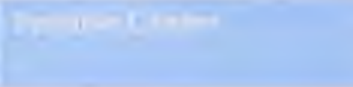 & inl of & Rivell smunces \\
\hline $\begin{array}{l}\text { Iodine } \\
\text { deficiency }\end{array}$ & $\begin{array}{l}\text { Ingestion of iodine deficient } \\
\text { feedstuffs. Most commonly } \\
\text { occurs in foals from mothers } \\
\text { that were fed a deficient } \\
\text { iodine diet. }\end{array}$ & $\begin{array}{l}\text { Most common in newborn foals. Foals will } \\
\text { be stillborn or born weak, with little or } \\
\text { no hair and with enlarged thyroid glands } \\
\text { (goiter). Some will have malformations in } \\
\text { limbs and parrot mouth. }\end{array}$ & Feed Iodized salt. \\
\hline $\begin{array}{l}\text { Iodine } \\
\text { excess }\end{array}$ & $\begin{array}{l}\text { Over supplementation } \\
\text { of iodine, usually with } \\
\text { kelp products. }\end{array}$ & Same as iodine deficiency. & $\begin{array}{l}\text { Remove } \\
\text { supplements } \\
\text { containing iodine. }\end{array}$ \\
\hline $\begin{array}{l}\text { Zinc } \\
\text { deficiency }\end{array}$ & $\begin{array}{l}\text { - Feedstuff deficiency. } \\
\text { - If fed }<40 \text { ppm, growing } \\
\text { horses will show signs } \\
\text { of deficiency. }\end{array}$ & $\begin{array}{l}\text { Reduced feed intake, reduced growth, } \\
\text { dandruff, hair loss, DOD. }\end{array}$ & $\begin{array}{l}\text { - TM salt. } \\
\text { - Mineral premix. } \\
\text { - Commercial } \\
\text { feed. }\end{array}$ \\
\hline Zinc excess & $\begin{array}{l}\text { - Over supplementation. } \\
\text { - Highly industrialized area. }\end{array}$ & DOD, stiff movement and lameness. & $\begin{array}{l}\text { Remove excess } \\
\text { zinc from diet and/ } \\
\text { or environment. }\end{array}$ \\
\hline $\begin{array}{l}\text { Iron } \\
\text { deficiency }\end{array}$ & $\begin{array}{l}\text { From chronic or severe } \\
\text { blood loss. } \\
\text { - Deficiency in the diet } \\
\text { is rare. }\end{array}$ & $\begin{array}{l}\text { Decreased oxygen carrying capacity of } \\
\text { red blood cells that results in decreased } \\
\text { athletic performance. } \\
\text { - Anaemia. }\end{array}$ & \\
\hline Iron excess & $\begin{array}{l}\text { - Due to excess injected iron. } \\
\text { - Unnecessary } \\
\text { supplementation. }\end{array}$ & $\begin{array}{l}\text { Decreased performance ability. } \\
\text { - Increased susceptibility to disease. }\end{array}$ & $\begin{array}{l}\text { Remove iron } \\
\text { supplementation. }\end{array}$ \\
\hline $\begin{array}{l}\text { Copper } \\
\text { deficiency }\end{array}$ & $\begin{array}{l}\text { Less than } 25 \mathrm{ppm} \text { in the diet } \\
\text { of growing horses. }\end{array}$ & DODs & $\begin{array}{l}\text { - TM salt. } \\
\text { - Mineral premix. } \\
\text { - Commercial } \\
\text { feed. }\end{array}$ \\
\hline $\begin{array}{l}\text { Copper } \\
\text { excess }\end{array}$ & Improper supplementation. & $\begin{array}{l}\text { - Hemolytic anaemia. } \\
\text { - Hepatic and/or renal damage. }\end{array}$ & $\begin{array}{l}\text { Remove excess } \\
\text { copper. }\end{array}$ \\
\hline
\end{tabular}

\section{CALCIUM AND PHOSPHORUS}

By far the most abundant minerals in the body are calcium and phosphorus. Calcium and phosphorus account for 40-50 per cent of the mineral content of a mare's milk.

As calcium, phosphorus and magnesium make up the bones and teeth, deficiencies and excesses will result in bone abnormalities, especially in growing horses. 
Table 12 outlines how much calcium and phosphorus horses should receive:

\begin{tabular}{|c|c|c|c|}
\hline \multicolumn{4}{|l|}{ 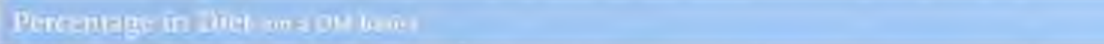 } \\
\hline Phwafolopeal ziat & Balcenom & Whe phionur & 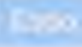 \\
\hline Maintenance & 0.3 & 0.2 & 1.5 \\
\hline Pregnancy (last 3 months) & 0.5 & 0.3 & 1.4 \\
\hline Lactation & 0.6 & 0.35 & 1.7 \\
\hline Weanlings (up to 1 year) & 0.6 & 0.35 & 1.7 \\
\hline Yearlings (up to 18 months old) & 0.5 & 0.3 & 1.7 \\
\hline
\end{tabular}

Table 12. Calcium and phosphorus needs of horses in different physiological stages

Horses in training often receive a much higher proportion of grain, which tends to have a low Ca:P ratio. In these cases a mineral supplement supplying the proper Ca:P ratio may be considered.

The largest change in calcium and phosphorus requirements can be seen in late gestation and lactation when the mare is depositing large amounts of calcium in the developing foal and then in her milk. During these times a calcium and phosphorus supplement is recommended to meet this increase in requirements.

Growing horses also have elevated calcium and phosphorus needs that are not supplied by hays and grains (Table 13). As such, a mineral supplement or commercial feed should be considered.

\begin{tabular}{|c|c|c|}
\hline \multicolumn{3}{|c|}{ 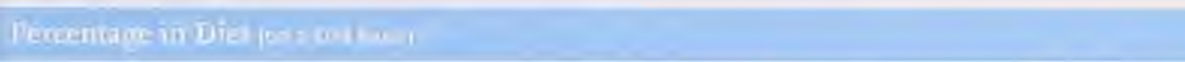 } \\
\hline & Gilerin: & Phinglimios \\
\hline Grains (oats, barley, corn) & $0.05-0.1$ & $0.3-0.4$ \\
\hline Bran & 0.1 & 1.3 \\
\hline Grass Hay & $0.3-0.5$ & $0.1-0.3$ \\
\hline Legume Hay (i.e. alfalfa) & $0.8-2.0$ & $0.1-0.3$ \\
\hline
\end{tabular}

Table 13. Amount of calcium and phosphorus commonly found in feeds

Adapted from Appendix 2, Lewis, L.D. Feeding and Care of the Horse (1995)

When feeding horses, it is most important that both calcium and phosphorus levels in the diet meet requirements, as both are required in certain amounts to form bone.

- the ratio of calcium: phosphorus should ideally be between 2:1 and 3:1; however, horses can tolerate levels up to 9:1

- the Ca:P ratio should never be below 1:1 (i.e. phosphorus intake should not exceed calcium intake) or dietary phosphorus will interfere with calcium absorption

For example, Miller's disease (big head disease) is a condition that affects horses that are predominantly fed wheat bran and, as a result, are fed more phosphorus than calcium. 
In this disease the bones become porous because the calcium is being sequestered out to meet the body's calcium demands. Although horses are good at identifying some mineral deficiencies, they are not able to determine that they are deficient in calcium or phosphorus. Additionally, some horses like the taste of the minerals (especially sweetened mineral blocks) and will overindulge, while others do not consume enough.

Calcium and phosphorus can be supplemented as:

- limestone (Ca only)

- monosodium phosphate (P only)

- dicalcium phosphate

- monodicalcium phosphate

- a complete vitamin/mineral premix

There are also mineral blocks and combined salt and mineral blocks available that contain calcium and phosphorus. Note that trace-mineralized salt does not contain calcium or phosphorus.

It is harder to feed free choice minerals in a group situation as some horses may consume less or more than they need. In a group situation, a complete vitamin/mineral premix can be fed as a crumble, the premix can be mixed in with grain, or alternatively, the premix can be mixed with loose salt to ensure a more consistent intake (two parts mineral to one part loose salt).

\section{Deficiency and Excess Signs of Calcium and Phosphorus}

In horses, calcium deficiencies can be caused by low calcium intake, or a Ca:P ratio that is less than 1:1. However:

- a phosphorus deficiency will not allow proper bone formation and will manifest itself as a calcium deficiency

- vitamin D can affect whether Ca is being absorbed into the body; therefore, a deficiency in vitamin D will also appear as a calcium deficiency

In young growing horses, a calcium, phosphorus or vitamin D problem will result in abnormal bone growth and, eventually, rickets. Rickets is due to improper bone mineralization. Symptoms include enlarged joints and crooked long bones.

Similar to growing horses, adult horses that do not receive adequate amounts of calcium and phosphorus, or if the ratio of $\mathrm{Ca}: \mathrm{P}$ is inversed, will first appear lame and the bones will weaken (osteomalacia). Fractures could become more common.

A large excess of calcium and vitamin D could cause abnormal bone growth, and calcification of the arteries. A calcium deficiency could result if there was an excess of phosphorus, or if the phosphorus intake was more than the calcium intake (a ratio of less than 1:1 Ca:P). The horse will then have inadequate bone mineralization and, as a result, bone abnormalities and weak bones will occur. 


\section{SODIUM CHLORIDE (Salt)}

Sodium is the major mineral or electrolyte involved in:

- the maintenance of the body fluids of the horse

- chloride functions that regulate nerve transmission

For a normal mature horse, salt should comprise 0.5 to 0.7 per cent of the total diet. Because sodium chloride is in such abundance in sweat, working horses or horses in hot, humid climates will require more salt.

With the exception of commercial horse feeds with added salt, most horse feeds are very low in sodium, and horses prefer their feed low in salt. Therefore, salt or sodium chloride should be provided free choice as loose salt or in block form. Loose salt is preferable in the winter for horses housed outdoors as their salt intake is greater.

Salt blocks can come in many different varieties, as either plain, iodized, iodized plus cobalt, or trace-mineralized. Salt can be fed free choice because horses have a distinct appetite for salt. When available, horses will ingest enough salt to meet their needs.

Each feed company may colour-code their salt blocks, so read the labels. As a general rule:

- plain salt is white

- iodized salt is light red

- iodized salt containing cobalt is blue

- trace-mineralized iodized salt is brown

Ideally, a trace-mineralized salt is recommended, as it will also provide the micro minerals in appropriate amounts and ratios. However if microminerals are provided from another source, such as commercial feeds or supplements, an iodized salt block is fine.

Generally, trace mineralized salt contains zinc, manganese, iron, copper, cobalt, and iodine but does not contain calcium and phosphorus. Combined salt and complete mineral blocks are available, and mineral premixes can also be mixed with loose salt to regulate the horse's intake (two parts mineral to one part loose salt).

\section{Salt Excess and Deficiency}

Horses can tolerate high salt intakes provided that they have free access to water. Salt toxicity only occurs if:

- the water provided to the horses is saline or high in total dissolved salts, or

- if more than two per cent salt is included in the diet and the horse doesn't have free access to water

The importance of a clean source of water has been described in the water section of this manual and should be considered in conjunction with dietary salt. Excessive salt consumption can be treated by having the horse frequently drink small amounts of salt-free water. 
Clinical signs of excess salt intake include:

- diarrhoea

- frequent urination

- colic, weakness

- lack of coordination

- inability to stand

- if not treated, death

Because horses consume salt to appetite, the only way in which a horse could exhibit a salt deficiency is if adequate amounts of salt were not made available to the horse. Allowing access to salt free choice at all times will prevent a salt deficiency.

If the horse is lactating or in training, salt deficiencies will occur more rapidly than normal as more sodium is lost in the milk or sweat.

In the case of exercising horses, a decrease in sweating will result in an increase in body temperature and a decrease in performance.

For exercising horses, an electrolyte solution containing sodium, chloride and potassium should be considered during periods of heavy exercise.

\section{POTASSIUM}

Potassium is another major mineral or electrolyte that is involved in the maintenance of the body fluids of the horse. Forages contain approximately two per cent potassium (on a DM basis) and the approximate requirement of potassium for mature horses is one per cent. Therefore, as long as horses are receiving appropriate amounts of forage in their diet then the potassium requirement is being met and supplementation is not necessary.

However, horses that are in training and exercising may need more potassium. This requirement may not be met if the horse is receiving a high grain diet that is low in potassium. If necessary, supplemental potassium can be supplied as part of an electrolyte mixture.

\section{Potassium Excess and Deficiency}

Potassium deficiency is characterized by:

- fatigue

- muscle weakness

- exercise intolerance

- an ultimately decreased feed intake

To treat a potassium deficiency, an electrolyte solution can be given orally every few hours until the horse begins to eat again.

On the other hand, excess potassium is readily excreted in the urine if water is available. If urine excretion is increased due to the use of diuretics, as is often the case with racehorses, potassium losses may be increased. Problems with potassium excess have only been recognized in hyperkalemic periodic paralysis (HYPP)-affected Quarter horses. 


\section{MAGNESIUMI}

Magnesium is mainly needed for bone growth and maintenance. Most feedstuffs for horses, from forages and oil seeds to grains, have magnesium concentrations that are generally $0.1-0.3$ per cent (on a DM basis). The requirement for horses is approximately 0.1 per cent of the diet (on a DM basis). This requirement for magnesium is usually met by the feedstuffs alone.

However, magnesium deficiency called "tetany," as diagnosed by low blood magnesium, has been reported in rare cases in lactating mares and in horses during stress and fasting.

Although more common in cattle, magnesium tetany can occur in early lactation in the horse and an injection of calcium and magnesium is given to rapidly alleviate the problem. Similarly, grass tetany can occur in horses fed very lush forage that is high in potassium and low in magnesium.

Symptoms of tetany are:

- nervousness

- muscle tremors

- lack of coordination

- increased respiratory rate

- sweating

- convulsions

Magnesium deficiency is not considered to be a problem in Western Canada.

\section{SELENIUIM}

Selenium works as an antioxidant to prevent damage to cell membranes. Selenium is usually considered together with the antioxidant vitamin E because they work together in the body.

The selenium concentration in normal feedstuffs for horses, ranges from 0.05-0.3 ppm and the requirement is estimated to be $0.1 \mathrm{ppm}$ (on a DM basis). The selenium concentration of the feed is also dependent on the growing conditions of the feedstuff, most importantly the soil selenium content and $\mathrm{pH}$ (selenium is deposited at a higher rate if the soil is alkaline).

Generally, North American soils are considered to be selenium deficient and, because of this, most commercial complete feeds will contain supplemental selenium. However, northern Alberta and the (acidic) grey wooded soils are lower in selenium than the black/brown alkaline soils of central and southern Alberta. Additionally, legumes, such as alfalfa, tend to contain higher levels of selenium compared to grasses, even when grown in selenium deficient soils.

Most commercial feeds and premixes have added selenium, but it can be highly toxic and therefore over supplementation is not recommended. Salt blocks with added selenium should be avoided if selenium is being supplied by other sources. If using salt blocks with added selenium, select a block that contains modest amounts of selenium at around 25-50 ppm. Horse-specific mineral supplements tend to supply selenium at a lower, safer range (20-25 ppm) than cattle minerals. 


\section{Selenium and Vitamin E Deficiency and Selenium Excess}

The risk of selenium/vitamin E deficiency in North America can be high in some regions.

Clinical signs are more common in foals than in mature horses and are mainly thought to be due to inadequate selenium/vitamin E intake by the mare during late pregnancy and early lactation.

Mild selenium deficiency results in a lowered immune system. Clinical signs of a selenium/ vitamin E deficiency include:

- "leaky" red cells

- inflammation of fatty deposits (yellow fat disease)

- degeneration of smooth, cardiac or skeletal muscle (white muscle disease in foals)

- degeneration of nervous tissue (wobbler's syndrome or myeloencephalopathy)

White muscle disease results in:

- weakness

- difficulties moving

- difficulty swallowing

- respiratory distress

- cardiac problems

To avoid selenium deficiency in foals in regions where selenium is known to be deficient in feeds, foals can be given a selenium injection at birth. Feeding pregnant and lactating mares selenium fortified or supplemented (0.1-0.3 per cent of the diet on a DM basis) feed can ensure that both mare and foal have enough selenium.

Selenium toxicity is mainly caused by inappropriate administration of selenium/vitamin E injections. Selenium levels at $3.3 \mathrm{ppm}$ in the diet can be lethal.

Symptoms of toxicity are:

- apparent blindness (often referred to as blind staggers)

- head pressing

- sweating

- colic

- diarrhoea

- increased heart and respiratory rate

- sluggishness

High hair selenium concentrations are indicative of selenium toxicity. Chronic selenium toxicity is characterized by dandruff around the mane and tail and cracking of the hooves around the coronary band.

Selenium toxicity is treated by removing selenium from the diet. Recovery is gradual. 


\section{IODINE}

Iodine is needed by the body in order to synthesize the thyroid hormones, which play an integral role in the regulation of metabolism.

Dietary iodine is of concern in certain areas of North America because soils may be iodine deficient. The most common areas in Canada for an iodine deficiency to occur are in areas close to the Great Lakes.

The iodine content of most horse feeds range from 0 to $2 \mathrm{ppm}$ and the horse's daily iodine requirement has been estimated to be $0.1 \mathrm{ppm}$.

Iodine deficiency is easily avoided by providing horses with access to iodized salt at all times.

Iodine excess can occur with iodine concentrations in the diet greater than five ppm when supplements high in iodine, such as kelp products, are fed. A supplement containing modest amounts of iodine is ideal (100 ppm), while supplements containing greater than $1000 \mathrm{ppm}$ are toxic to horses.

Providing an adequate amount of iodine to the mare during her pregnancy will avoid developmental abnormalities with the foal.

\section{lodine Deficiency and Excess}

Both iodine deficiency and excess are characterized by reduced thyroid function and enlarged thyroid glands. This is called goitre.

The thyroid glands are located near the jowl or throatlatch.

Goitre can also occur due to the ingestion of goitrogenic plants such as kale, white clover, turnips, and rutabagas, which are naturally high in perchlorates, nitrates, or thiocyanates and interfere with iodine metabolism.

Iodine deficiency and toxicity occur most commonly in foals because iodine accumulates in the placenta and milk. Affected foals may be stillborn or born weak, hairless, or with enlarged thyroid glands. Affected foals may be deformed and have mouth abnormalities (parrot mouth).

Avoid iodine deficiencies by supplying iodized salt to all classes of horses at all times.

Iodine excess can also appear to be an iodine deficiency, so consult a veterinarian or nutritionist to assess the problem.

Avoid feeding kelp products to minimize the risk of iodine toxicity.

\section{Feeds High in Nitrates, Iodine Deficiency and Foal Malformations}

The relationship between malformed foals and mares fed feeds high in nitrates is currently under debate. Foal malformations typical of iodine deficiency have been observed and there may be a link to feeds high in nitrates. Research has yet to confirm this relationship. 
Nitrates are accumulated in plants that are stressed. This stress may be caused by:

- a lack of water

- poor growing temperatures

- frost

Green feeds are sometimes at risk for high nitrate levels if the plants did not reach maturity due to some of the above environmental conditions.

High nitrate levels in feeds pose much more of a problem to cattle than to horses because of the differences in their digestive systems. One does not need to worry about killing horses with high nitrate feeds as one does with cattle.

It is recommended to have a feed analysis done if there is a potential concern about high nitrate contents. It is rare in Alberta that nitrate levels in feed reach levels to cause problems in horses. Tolerance levels for cattle are 0.5 per cent nitrates in the diet, and horses are believed to tolerate up to 1.0 per cent nitrates in the diet.

A recent study done with the University of Calgary, Olds College and Alberta Agriculture and Rural Development (Burwash, L. unpublished data) has shown that barren mares can tolerate two per cent nitrates in the diet with no adverse effects. Higher amounts of nitrates in the feed can lead to nitrate poisoning, characterized by respiratory problems and dark-brown urine.

High nitrate levels (whether in the water or in the feed) may interfere with iodine metabolism. As such, caution should be exercised with pregnant mares, where iodine deficiency (or excess) can manifest itself as problems in the foal.

Ensuring that pregnant and lactating mares have access to mineral supplementation and access to iodized salt is very important and will guard against problems with the foal. No matter what the level of nitrates in the feed, if there is an iodine deficiency (or excess) in pregnant mares, problems with foals may occur.

\section{ZINC}

Zinc is a part of the structure and function of some enzymes, especially those that regulate carbohydrate and energy metabolism. Zinc is also a major component of skin and hair and is important for normal bone growth.

While the recommended zinc intake for all classes of horses is 40-50 ppm, most feedstuffs contain only $15 \mathrm{ppm}$. Very few deficiency symptoms have been reported in mature horses fed diets containing $15 \mathrm{ppm}$, and supplementing zinc to mature horses has not been shown to be beneficial.

Conversely, there is some evidence demonstrating that growing horses fed supplemental zinc (at $60 \mathrm{ppm}$ ) have a lower incidence of abnormal bone and cartilage growth.

The following are the best sources of supplemental zinc for growing horses:

- commercial foal ration

- trace-mineralized salt

- vitamin-mineral premix 
Supplementation for the pregnant mare is also beneficial for the growth and development of the fetus.

\section{Zinc Deficiency and Excess}

A minor zinc deficiency will cause a decrease in feed intake and a reduction in growth rate.

If the zinc deficiency is severe, horses will also experience parakeratoses, which is characterized by poor skin health. Symptoms can range from patches of dry rough skin to what appears to be acne. Zinc deficiency will result in low serum or tissue zinc and can be diagnosed by a veterinarian.

Excess zinc is well tolerated by the horse; however, concentrations that are greater than $700 \mathrm{ppm}$ may result in developmental orthopaedic diseases (DOD).

Zinc excess is characterized by the following, all of which are likely due to zinc accumulation in the long bones:

- enlarged joints

- enlarged bone growth plates

- chronic swelling

- stiffness

Zinc excess is most likely to occur in industrial (smelter) areas.

\section{IRON}

Iron is an essential component of blood haemoglobin and muscle myoglobin and is important in carrying oxygen to all cells in the body.

The horse's requirement for iron is estimated to be approximately $50 \mathrm{ppm}$ for all classes.

Forages contain between 50-400 ppm and cereal grains contain between 20-100 ppm; therefore, common feeds for horses will easily meet the iron requirement.

\section{Iron Deficiency and Excess}

Iron deficiency in normal, healthy, growing and adult horses is rare.

An iron deficiency can be characterized as reduced blood ferritin levels (not iron levels.) Affected horses will have decreased exercise capacity due to a reduction in red blood cells that carry oxygen to the muscles. This will eventually lead to anaemia.

Because iron deficiency is rare and is most likely due to blood loss, it is likely that a secondary problem exists and a veterinarian should be consulted. Iron dextran injections (intramuscular) should only be given to horses with a severe deficiency and only if recommended by a veterinarian as they can be harmful. Furthermore, although many species of animals are given iron injections at birth, the foal is born with a relatively high tissue concentration of iron and does not require an iron injection. 
Iron is sometimes supplemented to improve the capacity of blood to deliver oxygen to the muscles in exercising horses. There are no known benefits associated with supplemental iron for nonanaemic horses. Excess iron will decrease disease resistance and can result in iron accumulation in organs, which may lead to liver failure.

\section{COPPER}

Copper is involved in bone maintenance and haemoglobin function.

Common horse feeds contain 0.05-40 ppm copper. A copper requirement has not been established but is noted as $10 \mathrm{ppm}$ for all classes of horse.

However, Alberta feeds are reported to be deficient in copper (4-6 ppm), and this may be of concern for young, growing horses and pregnant mares. Copper deficiency has not been reported in adult horses but may occur in young growing horses.

Deficiency of copper in young growing horses results in:

- anaemia

- decreased bone density

- increased incidence of developmental orthopaedic diseases (DOD)

For this reason, it is recommended that creep feeds contain $50 \mathrm{ppm}$ and weanling feeds contain $25 \mathrm{ppm}$. In addition, copper should be supplemented to all mares in gestation.

Researchers in New Zealand (Pearse et al., 1998) have shown that copper supplementation for the pregnant mare is beneficial for reducing incidence of DOD in the foal. Copper can be supplemented in the form of:

- commercial horse feeds

- trace-mineralized salt

- vitamin-mineral premixes

Such supplementation may decrease the occurrence of DOD in young horses.

Chronic excess copper intake of $1000 \mathrm{ppm}$ is likely to cause organ damage, but generally horses are resistant to excess copper intake. 


\section{OTHER MINERALS}

There are many other minerals in the diet of horses that are necessary for numerous functions; however, either the requirement of these has not been determined or symptoms of deficiency or excess are of yet to be produced or are extremely rare.

- There is no known requirement for fluoride, but it functions to maintain teeth and bone hardness.

- Sulphur is important for the structure of bones, hooves and hair. Sulphur is present in the diet in numerous forms and a deficiency has never been reported.

- Manganese is important for carbohydrate and lipid metabolism and for cartilage formation via chondroitin sulphate synthesis. Manganese deficiency manifests as abnormal cartilage development, enlarged joints, and shortened forelimb bones, but a deficiency is rare.

- Cobalt is a necessary component of vitamin B12 and if it is deficient in the diet will result in a vitamin B12 deficiency. The microflora present in the colon and cecum of the horse use cobalt to synthesize vitamin B12. Cobalt deficiency has not been reported in horses.

\section{GENERAL TIPS: MINERALS}

- Minerals work together and an ideal balance should be maintained.

- Calcium and phosphorus in the diet should meet the horse's needs. This is especially important for pregnant and lactating mares, and growing horses.

- Horses have a requirement for salt (sodium chloride) and offering free choice salt along with other minerals (trace-mineralized salt or complete salt-mineral mixes) can help avoid any potential deficiencies. Offer iodized salt to help avoid an iodine deficiency.

- Many commercial horse feeds will add selenium because most soils in North America are selenium deficient. Selenium supplementation is most important for pregnant mares and foals at birth. Selenium can be supplemented at one per cent of the total diet.

- Growing horses should receive a well-balanced diet containing adequate minerals, especially of calcium, phosphorus, zinc and copper. 


\section{VITAMINS FOR HORSES}

Although vitamins are required only in small quantities they are involved in fundamental body functions. The Latin meaning of the word vitamin is "life."

There are two types of vitamins:

- fat-soluble vitamins (vitamins A, D, E, and K)

- water-soluble vitamins (the B vitamins and vitamin C)

The fat-soluble vitamins are stored in the fat associated with fat tissues, and are therefore conserved for longer periods of time. For example, a horse stores vitamin A from grass eaten in the summer for use over the winter when green grass is not available.

The water-soluble vitamins are not stored in the body and are readily excreted in urine.

- all B vitamins are synthesized by the micro-organisms in the horse's large intestine and are not required under normal circumstances in the horse's diet

- vitamin $\mathrm{C}$ is synthesized by the horse's liver and is not required in the diet

Vitamin requirements are expressed as international units, or IU, which refer to the vitamin's activity.

Horses with access to green grass in the summer and with good quality nutrition will normally not need any vitamin supplementation.

However, vitamin supplementation can be considered when:

- the horse has no access to green grass or good quality fresh hay (vitamins A, D and E)

- there is prolonged antibiotic use, anaemia or illness, or poor nutrition, all of which greatly reduce the quantity of intestinal bacteria available to produce vitamins (vitamins $\mathrm{K}$ and $\mathrm{B}$ )

Supplementation of all vitamins may be beneficial when a horse is:

- fed a high grain, low forage diet

- under stress or intense exercise, with little access to the outdoors and green pasture

As can be seen in Table 14 below, the symptoms of a vitamin deficiency are closely related to the vitamin's functions in the body. In some cases, excess vitamin supplementation can be very harmful. 


$\begin{array}{ll}\text { Vitamin A } & \text { Obtained solely } \\ \text { deficiency } & \text { through feed } \\ & \text { - Fresh forages } \\ & \text { - Coloured (green, orange, } \\ & \text { yellow) plants } \\ & \text { - Dried forages }\end{array}$

Vitamin A excess Vitamin A injection

Vitamin D
deficiency

Vitamin D excess

Vitamin E

deficiency and combined vitamin

$\mathrm{E}$ and selenium

deficiency

Vitamin E excess

Vitamin K

deficiency

$\begin{array}{ll}\text { Vitamin K excess } & \begin{array}{l}\text { Vitamin K injection } \\ \left(\text { Vitamin } \mathrm{K}_{3}\right)\end{array} \\ \begin{array}{ll}\text { B vitamins: } \\ \text { deficiency }\end{array} & \begin{array}{l}\text { Produced by microbes } \\ \text { in gut }\end{array} \\ & \cdot \text { Brewer's yeast } \\ & \cdot \text { Grains }\end{array}$

B vitamins excess

Vitamin C

deficiency

Vitamin C excess

- Synthesized under skin from cholesterol by exposure to UV light (sunlight)

- Dried forages

Vitamin D supplements

\section{Obtained solely through feed}

- Fresh forages

- Oilseeds

- Oils and fats

Produced by microbes in gut

Produced by horse's liver

Vitamin C supplements
Problems with blood clotting

Renal failure

- For most B vitamins, deficiency symptoms have never been demonstrated

- Poor appetite

- Low energy

- Anaemia (Folate, B12)

None: excess B vitamins are readily excreted in urine Low energy
(1) nit

- No access to fresh forages

- Poor quality hay (old and/ or poorly stored)

Unnecessary

supplementation of vitamin A

- No exposure to sunlight

- Poor quality hay (old and/ or poorly stored)

Over supplementation of vitamin D

- No access to fresh forages and Poor quality hay (old and/or poorly stored)

- High fat diet

- Selenium deficiency

- Mouldy sweet clover poisoning

- Unhealthy gut microbes (see B vitamins)

Inappropriate administration of vitamin $\mathrm{K}$

- Thiamine: bracken fern poisoning

- Unhealthy hindgut microbes: from long-time antibiotic use, low feed intake, poor quality feed, high grain diet, illness

Table 14. Vitamins needed by the horse, deficiency and excess symptoms and causes 


\section{VITAMIN A}

The horse cannot synthesize vitamin A or vitamin E. These are the only two vitamins that need to be supplied entirely by the diet.

Vitamin A is responsible for maintenance of rhodopsin, a pigment in the retina required for night vision. It also functions to maintain epithelial cells, such as skin and the cells lining the digestive, respiratory, reproductive and urinary tracts.

Vitamin A is obtained by the horse mainly in its pro-vitamin form; beta-carotene. Coloured plants (orange, yellow and green) are good sources of beta-carotene, which can then be converted into the active form, vitamin A, by the horse's intestinal cells.

Fresh green forages are an excellent source of vitamin A, and good quality hay (under one year old) is more than adequate. Stored hay will lose 10 per cent of its vitamin A content per month.

A horse that grazes on pasture for only four to six weeks during the summer will store enough vitamin A for the winter, and requirements can easily be met by feeding fresh hay over the winter.

Vitamin A requirements of the horse are listed in Appendix 2.

\section{Deficiency and Excess of Vitamin A}

Symptoms of a vitamin A deficiency include:

- night blindness

- excessive tear production

- hardening of the skin and cornea (cloudy corneas)

- respiratory and reproductive problems

Excess vitamin A is very harmful and toxicity only occurs when supplemented as vitamin A. If the diet is high in beta-carotene, the horse will avoid toxic levels by converting less of the betacarotene into vitamin A.

Symptoms of vitamin A toxicity are:

- reduced appetite and growth

- anaemia

- poor hair and skin

\section{VITAMIN D}

Vitamin D is synthesized from cholesterol under the skin of horses by sunlight. It can also be obtained from the diet, and sun-cured hay is also high in vitamin D.

Vitamin D is very important as it functions as a binding protein required for calcium absorption. A calcium deficiency will result if the horse is deficient in vitamin D. 
However, extra vitamin D supplementation is not recommended, nor beneficial unless a horse:

- does not have access to the outdoors during the summer

- is not fed good quality hay during the winter

Often a vitamin premix will contain vitamin $\mathrm{A}, \mathrm{D}$ and $\mathrm{E}$ in set proportions (5 IU vitamin $\mathrm{E}$, 150 IU vitamin D per 1000 IU of vitamin A), as vitamin E and vitamin D enhance vitamin A absorption and storage.

\section{Deficiency and Excess of Vitamin D}

Since vitamin D functions to absorb calcium into the body, deficiency symptoms are the same as for a calcium deficiency:

- stiffness

- lameness

- swollen joints

- brittle, porous bones in young (rickets) and older (osteomalacia) horses

Toxic levels of vitamin D result in calcification of soft tissues and excess bone formation resulting in bone abnormalities.

\section{VITAMIN E}

Vitamin E, like vitamin A, is obtained only from the diet. It has important functions in the body as an antioxidant in conjunction with selenium. It protects cell membranes from oxidative damage that would otherwise result in cell death. It also:

- is essential for DNA synthesis

- enhances immune function

- is a cofactor for vitamin C synthesis

- enhances vitamin A absorption and storage

It is stored in the body for months.

Young green plants are good sources of vitamin E. However, vitamin E is easily oxidized and sensitive to moisture, grinding, storage and heat. Harvesting forage into hay will automatically reduce the vitamin $\mathrm{E}$ content by 70 per cent, and it will continue to drop during storage.

The requirements for vitamin E are $50 \mathrm{IU} / \mathrm{kg}$ DM of feed for mature horses and 80-100 IU/kg DM for foals, broodmares and working horses, whereas a typical legume or grass hay will only contain 5-25 IU/kg DM. As such, vitamin E should be supplemented in horses with no access to green pasture during the summer months. 


\section{Deficiency and Excess of Vitamin E}

Symptoms of vitamin E deficiency relate to this vitamin's ability to protect cell membranes from damage, and will include combined vitamin E/selenium deficiencies. Problems include:

- pale areas of skeletal muscle or white muscle disease

- yellow-fat disease that occurs mainly in foals

- equine degenerative myeloencephalopathy or wobbler's syndrome (degeneration of the myelin sheath that protects nerves)

Unlike vitamins A and D it is relatively non-toxic, and can be supplemented, especially if the horse has no access to green pasture.

Vitamin E/selenium combinations are used in the treatment of "tying up." Symptoms of tying up:

- horse is reluctant to move after heavy exercise

- the urine is often dark brown due to haemoglobin release from damaged blood cells

\section{VITAIMIN K}

Vitamin $\mathrm{K}$ is largely synthesized by the microflora in the large intestine of the horse and can be obtained from leafy green plants. Vitamin $\mathrm{K}$ is essential for several factors involved in blood clotting. There is no requirement for vitamin $\mathrm{K}$ in the horse's diet.

Ill horses on prolonged antibiotic use and no access to good hay, or receiving very poor nutrition, may hay not synthesize enough vitamin K. Supplementation should only under recommendations from a veterinarian.

\section{Deficiency and Excess of Vitamin K}

The only deficiency reported for vitamin $\mathrm{K}$ is in horses eating moldy sweetclover. Non-moldy sweetclover poses no problems to the horse, but a compound in sweetclover called coumarin can be converted to dicoumarol (which is a typical ingredient in rat poison) by penicillin moulds. The dicoumarol interferes with synthesis of vitamin K-dependent blood clotting factors.

Vitamin K has sometimes wrongfully been given to treat "bleeders" on the notion that it will improve blood clotting and thereby reduce bleeding into the lungs caused to heavy exercise. This type of "bleeders" is called exercise-induced pulmonary haemorrhage. It is caused by breakage of blood vessels in the lungs and not due to improper blood clotting.

Although oral supplementation is safe, it can cause renal damage and death if given in excess via injection. 


\section{B VITAMINS}

The vitamins that are typically mentioned are:

- $\mathrm{B}_{6}$ (pyridoxine)

- $\mathrm{B}_{2}$ (riboflavin)

- $\mathrm{B}_{1}$ (thiamin)

- $\mathrm{B}_{12}$ (cobalamin)

- $\mathrm{B}_{3}$ (niacin)

- folic acid

- pantothenic acid

- biotin

- choline

All of these are synthesized in the large intestine by microflora in adequate amounts for horses. This in contrast to other monogastrics, such as the pig and human, that do require a source of B vitamins from their diet. However, these vitamins are readily excreted in the urine because they are highly toxic to the horse, and excretion is the horse's defence against toxicosis. Supplementation of B vitamins will do no harm; at worst it will just turn into expensive horse urine.

There are currently no requirements for B vitamins in the horse, except for thiamine. However, the requirement is three $\mathrm{mg} / \mathrm{kg} \mathrm{DM}$ for all horses except those in heavy exercise or growth, where the requirement moves to five $\mathrm{mg} / \mathrm{kg} \mathrm{DM}$. As cereals contain between four and seven $\mathrm{mg} / \mathrm{kg} \mathrm{DM}$ and hays between three and four $\mathrm{mg} / \mathrm{kg} \mathrm{DM}$, this should not need to be supplemented.

Thiamine deficiency can result from bracken fern poisoning. Bracken fern contains thiaminase activity that breaks down thiamine, leading to deficiency. Symptoms are:

- weight loss

- neural dysfunction

- depression

Bracken fern does need to be consumed in large amounts (hundreds of pounds) in order to cause this problem. Bracken fern is also different to other poisonous plants as horses develop a taste for it.

Riboflavin and niacin are important for carbohydrate metabolism, but the horse and the microflora in the horse's gut synthesize these vitamins. Supplementation is of little benefit.

Vitamin B12 and folate function in red blood cell synthesis. A deficiency of either of these two vitamins results in anaemia. Anaemic, heavily parasitized horses respond to supplementation of these two vitamins, but a veterinarian should judge the cause of anaemia and the appropriate course of action in this situation. 
The only B vitamin where supplementation has questionable benefits is biotin. Biotin is a sulphur-containing vitamin that is important for hooves and skin. Although a deficiency is rare, it may be beneficial for horses with brittle, cracked hooves. From research studies, biotin supplementation seems to work for some defects, but not others. However it can take years to see the beneficial results. Consult with a farrier if concerned about the health of a horse's hooves.

B-vitamin supplementation may be practical:

- where feed intake is limited

- ill or heavily parasitized horses

- heavily exercised or stressed horses

- those on prolonged antibiotics

In these situations, the intestinal microflora may not synthesize enough vitamin $\mathrm{K}$ or $\mathrm{B}$. Unnecessary supplementation is essentially a waste of money.

\section{VITAMIN C}

The horse's liver synthesizes this vitamin readily and horses do not require vitamin C. Geriatric horses with liver problems may see benefit to vitamin C supplementation.

\section{GENERAL TIPS: VITAMINS}

- Generally, vitamin supplementation is not required for healthy horses on diets consisting of good quality forage

- Vitamins A and E should be supplemented to horses that do not have access to pasture in the summer or good quality fresh hay. Vitamins A and E are lost during processing of hay and during storage.

- Vitamin D is provided by sun-cured forage and is synthesized by the horse in response to sunlight. If a horse does not have access to the outdoors and sun-cured forage, supplementation should be considered.

- B vitamin supplementation could be considered for heavily exercising horses.

- A veterinarian may suggest supplementation of vitamins B and $\mathrm{K}$ for horses that are ill, not eating or during prolonged use of antibiotics.

- There is no need for supplementation of vitamin C in mature, healthy horses. 


\section{FEEDSTUFFS}

The variety of feeds available for horses spans a wide range of ingredients, but the backbone of any feeding program is forages, either as pasture or hay.

For horses that are growing, pregnant, lactating, or in heavy training supplemental feed will be required to increase both the energy and protein density of the diet.

Different feeds contain different amounts of water, energy, protein, vitamins and minerals.

When choosing a feedstuff, one should also consider the palatability of the feedstuff. Palatability can be affected by:

- anti-nutritional factors (i.e. tannins)

- odour

- physical characteristics (i.e. texture, bulk)

Decreased palatability results in a decrease in feed consumption and reduced body condition.

\section{FORAGES}

Horses should predominantly be fed pasture or hay as the basis of their diet. Horses should be provided 1.5 to 2 per cent of their body weight in the form of forages or roughages. They should never be provided these at less than one per cent of body weight.

A minimum of one per cent of body weight in forage or roughage is important for a healthy digestive tract and minimal complications such as colic or founder.

Generally, horses that are growing, working, pregnant or lactating are fed as much good quality hay as they can eat. Additional energy and protein are only added if required.

The majority of the horse's diet consists of forages and roughages because they are high in fibre. Forages are the stems, stalks, leaves and heads of plants, with or without the seeds or grain.

Pasture and hays and cereal hays are considered forages. Roughage is non-forage feed that is high in fibre and low in digestible energy, including cereal grain hulls, beet pulp, fruit pomaces, and corncobs. 


\section{TYPES OF FORAGE}

The following is a general idea of the nutrient content of different hays and types of forages (also see Appendix 1).

\begin{tabular}{|c|c|c|c|c|c|c|c|c|c|c|c|}
\hline Ifor int & Bha & tors & $6 x^{2}$ & E & & 38 & $\mathrm{E}$ & $\sin$ & 38 & $\frac{\pi n}{\pi}$ & $\frac{B 0}{8 P^{2}}$ \\
\hline Alfalfa & 89 & 2.45 & 17.9 & 1.76 & 0.22 & 0.31 & 1.82 & 41 & 0.28 & 25 & 7 \\
\hline $\begin{array}{l}\text { Mixed } \\
\text { (alfalfa/grass) }\end{array}$ & 90 & 2.39 & 14.8 & 1.58 & 0.18 & 0.24 & 1.35 & 48 & 0.35 & 23 & 6 \\
\hline Brome & 89 & 2.03 & 9.6 & 0.52 & 0.16 & 0.15 & 1.64 & 72 & 0.16 & 19 & 5 \\
\hline Timothy & 88 & 1.93 & 8.3 & 0.48 & 0.14 & 0.12 & 1.22 & 48 & 0.11 & 21 & 4 \\
\hline Native grass & 90 & 1.92 & 8.2 & 0.46 & 0.13 & 0.13 & 0.98 & 55 & 0.13 & 20 & 4 \\
\hline $\begin{array}{l}\text { Creeping red } \\
\text { fescue }\end{array}$ & 88 & 2.04 & 9.4 & 0.56 & 0.18 & 0.18 & 1.63 & 130 & 0.16 & 19 & 6 \\
\hline Orchardgrass & 88 & 2.28 & 12.9 & 0.51 & 0.21 & 0.29 & 1.89 & 93 & 0.3 & 26 & 7 \\
\hline $\begin{array}{l}\text { Oat hay } \\
\text { (greenfeed) }\end{array}$ & 87 & 2.06 & 9.4 & 0.37 & 0.21 & 0.20 & 1.74 & 54 & 0.15 & 23 & 5 \\
\hline 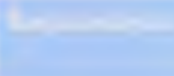 & & $\begin{array}{r}2.0- \\
3.0\end{array}$ & $\begin{array}{r}8.0- \\
15\end{array}$ & $\begin{array}{r}0.3- \\
0.8\end{array}$ & $\begin{array}{r}0.2- \\
0.5\end{array}$ & 0.1 & $\begin{array}{r}0.4- \\
0.6\end{array}$ & 20 & $\begin{array}{r}0.1- \\
0.2\end{array}$ & $\begin{array}{r}40- \\
60\end{array}$ & $\begin{array}{r}10- \\
25\end{array}$ \\
\hline
\end{tabular}

Table 15. Values are means that represent feeds analyzed at the Alberta Agriculture Soil and Feed Testing Laboratory, 1967-1994.

Except for DM \%all values are on a $100 \%$ DM basis.

$\begin{array}{llllll}\text { \% DM } & \text { \% dry matter } & \mathbf{P} & \text { phosphorus } & \text { Se } & \text { selenium } \\ \text { DE } & \text { digestible energy } & \mathbf{M g} & \text { magnesium } & \mathbf{Z n} & \text { zinc } \\ \mathrm{CP} \% & \text { crude protein } & \mathbf{K} & \text { potassium } & \mathbf{C u} & \text { copper } \\ \mathrm{Ca} & \text { calcium } & \mathbf{M n} & \text { manganese } & & \end{array}$

\section{Legumes}

Compared to grasses, legumes are rich in energy, protein and calcium. They have the ability to fix nitrogen through the action of nitrogen-fixing bacteria that reside on the root system on the plants, resulting in much higher protein content than non-legumes. However, legume hay is more difficult to harvest and cure, and dusts and moulds are more common in legume hays than grass hays.

Legumes are excellent, high quality feeds for horses, especially for those with higher energy and protein requirements such as growing horses and broodmares in late gestation and lactation. 
Alfalfa is the most common legume used for long hays, cubes or pellets and often comprises a portion of any hay for horses. Alfalfa:

- is excellent quality

- contains high amounts of protein and calcium

- is well liked by horses

It is easily grown in Western Canada because it is fairly drought resistant.

Later cuts of alfalfa $\left(2^{\text {nd }}\right.$ or $\left.3^{\text {rd }}\right)$ usually contains higher levels of energy and protein than the first cut because the forage can be harvested at earlier, less mature stages of growth. These later cuts also have a higher leaf to stem ratio, making them more desirable.

Clovers are legumes and like alfalfa provide higher protein, energy and calcium than grasses. They are not commonly used for feeding horses, but they can be fed if the hay is free of dust or mould. Clovers are often found in mixed clover/grass hay.

Common clovers are red, white, alsike and sweetclover. Alsike clover should be avoided as it can cause liver damage and photosensitivity in horses. Other clovers are fine, as long as the hay is not mouldy.

Sweet clovers are often used for horses, but mouldy sweetclover can be a problem. The mould causes a compound to be formed, dicoumarol, which blocks blood coagulation. Mouldy red clover can cause "slobbers" or excessive salivation in the horse.

\section{Grasses}

Timothy is commonly mixed with alfalfa in a legume/non-legume mixed hay to balance for the high nutrient density of alfalfa. While it has adequate protein for the mature idle horse, any other class of horse will need protein (and energy) supplementation.

If handled properly and cut early, brome grass is higher in nutrient density than other grass hays. This, and the fact that brome is suited for almost all soil types, means brome hay is commonly used in Canada

Orchard grass is not a common grass for horses, but it is high in protein and energy compared to other grass hays.

Creeping red fescue has good tolerance to drought and will stand heavy grazing. Although it has a good nutrient profile, horses do not find it as palatable as many other pasture grasses. Tall fescue can make excellent hay but caution should be taken as mares in late gestation should be fed only an endophyte-free species.

\section{Green Feed (i.e. Cereal Hay)}

Green feed is a cereal crop that is harvested when the grain is in the late milk to dough stage. It is an excellent feed for horses, especially those that are mature or idle. It has similar energy, protein and mineral values to good quality grass hay.

If most of the cereal heads fall off, the hay will become little more than straw and it will lose most of the nutrient content. 
Cereal crops are often made into green feed because conditions were not optimal for the cereal to mature properly. Plants that do not reach maturity due to poor weather conditions (such as poor temperatures or moisture levels, drought stress or frost) can accumulate nitrates.

Horses can handle higher nitrate levels than cattle, but levels of nitrates $\left(\mathrm{NO}_{3}\right)$ higher than one per cent in the feed are not considered safe. On average, oat greenfeed in Alberta contains 0.26 per cent nitrates, which is safe. However, if the crop has been damaged by frost or drought, nitrate levels can exceed 1.85 per cent, which is toxic to ruminants.

If pregnant mares are being fed green feed, ensure that nitrate levels are below one per cent, and that the mare is proper iodine supplementation (iodized salt). See the section on nitrate poisoning for more information.

\section{FEEDING FORAGES}

- Forages are highly variable in nutrient content and, if possible, each cut of hay should be analyzed for nutrient content.

- Roughages, such as beet pulp and alfalfa cubes, can replace hays in horses diets.

- There are many species of grasses for horses. Some are better as pasture grasses and some species are good for hay.

- Legume hays are much higher in protein, energy and calcium than grass hays. This makes alfalfa, or mixed alfalfa/grass hay, an excellent choice for horses with increased requirements such as for growth, pregnancy, lactation or for performance. A mineral supplement containing phosphorus (with low calcium such as a 1:1 mineral) and trace minerals is all that is necessary.

\section{Tips For Feeding Legume Hay}

- As with all changes to the diet, legume hay and or pasture should be introduced gradually.

- Alfalfa does not cause bloat in horses as it does in cattle.

- While high protein intakes (i.e. when feeding legume vs. grass hays) cause an increase in water consumption and urination it does not appear to damage the horse's kidneys.

- Take care to select good quality product as legume hay is more prone to moulds and dusts than grass hay.

- Legume hay is highly digestible, contains high levels of nutrients and is well liked by horses. It may have to be limit-fed, especially to horses that are easy-keepers or tend to founder.

\section{SELECTING HAY FOR HORSES}

Horses should always be fed hay that is of good to high quality. Poor quality hays will reduce feed intake and will cost more money in a feeding program due to necessary supplementation to meet the horse's requirements. When selecting hay, there are a number of factors to consider.

First, haty should be free of both moulds and dust. Moulds can be produced by rain and weather damage or when the hay is baled at too high a moisture content. Early cut hay should be cut and 
dried to approximately 12 per cent water content and later cut hay should be dried to 15-17 per cent water content to avoid mould growth and fermentation. Hay that has begun to mould will often be warm or dusty.

Horses are highly susceptible to respiratory problems caused by mould and dust. This can manifest as a cough and a runny nose or a more serious and longer lasting respiratory illness called heaves. When purchasing hay, feel for both heat and moisture in the bale by pressing your hands in between the flakes.

Second, hay should be evaluated for its leaf to stem ratio. Hay should have a high leaf to stem ratio, at least 50:50. The higher the leaf to stem ratio (the more leaves that are present), the higher the nutrient value of the hay.

When examining legume hays (i.e. alfalfa and clover predominantly), remember that the leaves of legumes are lost more easily than grasses. The more leaves legume hay loses, the poorer the nutritive value of that legume. Leaf loss may also mean that the hay was baled too dry.

Third, colour should be used as a criterion. Hay and forages should be a fresh green colour. Hay and forages that have been weather or rain damaged will have a much more pale appearance. If it rains after the hay is cut and before it is baled, the hay will require further drying time but will also become weather damaged and lose nutrients.

Fourth, use smell as a criterion. Hay should have a clean sweet smell indicating proper curing. Beware of a "caramel" smelling hay which indicates the presence of heat and improper fermentation.

Fifth, age of the hay should be a criterion. The later in the season the hay is cut, the lower the nutrient value due to a general increase in partially available and the non-digestible portion of the stem.

Stems of hay should be soft and pliable as opposed to course and stick-like. When purchasing hay, look for the presence of blossoms and seed heads (large numbers of seed heads and blossoms indicate maturity). Late cut forages, such as alfalfa, may have a decreased leaf to stem ratio due to leaf loss due to the late cut of the forage.

Finally, the presence of weeds should be a criterion. Hay and forages should be free of weeds and other extraneous material. Weeds are not as palatable and will lower the overall nutrient value of the hay or forage. The presence of thistles and alsike clover is undesirable.

All of the above factors are important in selection of hay. However, none of them are indicative of overall nutritive value. A lab analysis will determine the nutritive value of the hay.

Poor quality hay provides fewer nutrients than high quality hay. It may be necessary to supplement horses receiving poor quality hay with:

- energy

- protein

- vitamins

- minerals

Good quality hay is always your best value. 


\section{HOW TO GET YOUR HAY ANALYZED}

To obtain a representative hay sample, each lot of hay (whether a different cut or obtained from different producers) should be sampled to obtain a representative sample.

In addition, a grab sample is not representative while a "core" sample is representative. To obtain "core" samples, a hay corer or probe can be used to take samples of the hay through the entire bale. Sample bales (at least 20) and put all samples into a pail or bag. Mix all the samples together to obtain the most representative sample of the hay at your farm.

Hay samples should be analyzed for the following basics:

- Moisture content - gives an indication of the dry matter content of the feed.

- Acid detergent fibre (ADF) - this is an indicator of the nutrient content in the feed and is used to obtain a value for digestible energy

- Energy - It is preferred that the feed testing laboratory provides energy values for horses. If they don't, ask for the ruminant analysis. Analyze the hay for ruminant energy (given as digestible energy). This is high for horses, so add a correction factor of 0.85 to reduce the energy level for horses.

- Per cent crude protein - a measure of the amount of protein present in the feed. This is not an indicator of quality of protein present, but the total protein present.

- Per cent calcium in feed.

- Per cent phosphorus in feed.

Other optional analyses include:

- trace minerals, such as zinc, copper, manganese

- selenium

- nitrates

- non-structural carbohydrates

\section{Hay Cubes and Pellets}

Suncured alfalfa is typically processed and compressed to produce cubes, whereas dehydrated alfalfa is processed into pellets. Newer products include mixed alfalfa/grass cubes.

These hay products are used for the following reasons:

- There will be less wastage.

- Horses often will eat more pelleted or cubed hay than loose hay. This is advantageous if additional feed intake is necessary (such as in lactation and heavy exercise).

- Bags of hay cubes or pellets take up less storage space and can be easily bought and transported throughout the year.

- Lower dust than loose hay.

- Nutrient quality is guaranteed.

- For horses with bad teeth or digestion problems, soaked alfalfa cubes are a good option.

- Reduce manure.

- When travelling into areas that require weed-free hay. 
Disadvantages of using cubes or pellets are the higher cost and reduced eating time, which may lead to boredom and related vices (such as wood chewing).

As alfalfa cubes are also rich in energy and highly digestible they should be limit-fed to no more than two per cent of body weight.

Lastly, for horses that choke, it may be necessary to soak cubes and pellets.

\section{Straw}

Straw and chaff are too low in energy and protein content to be considered as a feed for horses.

Straw can be fed in situations to increase fibre intake, provided that the horse's nutrient needs are being met through feeding good quality hay or concentrates.

\section{Silage and Haylage}

Silage and haylage are cut and immediately stored in plastic covers or are stored in a silo under conditions of little to no oxygen (anaerobic). Green feed is often also ensiled.

When grains are ensiled, anaerobic bacteria begin to ferment the soluble carbohydrates or fibre and produce volatile fatty acids, much like in the hind gut of the horse.

If ensiled properly, ensiled hay or green feed can be preserved for years. If the silage is improperly stored and exposed to oxygen, aerobic bacteria will proliferate and the silage will heat and spoil.

For silage or haylage stored in plastic covered bales, ensure:

- the covering is not compromised

- that the $\mathrm{pH}$ is below 4.5

- it smells good

Horses are highly sensitive to moulds and bacterial toxins, which can have harmful effects on the horse's health.

Silage can be fed to horses. It is palatable, and is an excellent feed source if ensiled properly. Introduce silage gradually to the diet. It takes about three $\mathrm{kg}$ of silage to replace one $\mathrm{kg}$ of hay (90 per cent dry matter).

Young growing horses are unable to eat enough silage to meet their nutrient requirements and require supplementation.

\section{PASTURE MANAGEMENT}

A properly managed pasture can provide excellent nutrition for horses. It is high in energy, fibre, protein, essential fatty acids, minerals and vitamins. Even small holdings with a few acres can be carefully managed to allow access to good grazing.

Consult Alberta Agriculture and Rural Development's booklet Manure and Pasture Management for Horse Owners (Agdex 460/27-1) for some excellent information on how to manage horse pastures. 
Some good rules to follow for pasture management are:

- Take half, leave half (see Figure 7 below). Pastures should not be grazed until growth has reached $15-20 \mathrm{~cm}$ high and grazing should stop when the grass is $8-10 \mathrm{~cm}$ high. Grazing lower than five $\mathrm{cm}$ may compromise future re-growth and result in increased weed growth. Overgrazing is the most serious pasture problem in Alberta.

- The appropriate stocking rate is four to six acres per horse for cultivated pasture and 8-12 acres per horse for native pasture during the summer.

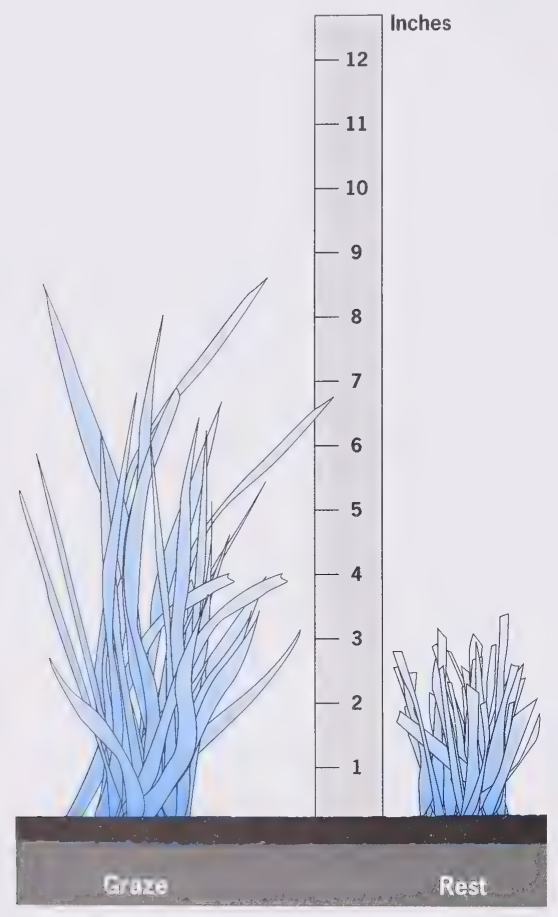

Figure 7. Pasture grazing lengths

\section{SELECTING CONCENTRATES FOR HORSES}

Grains are seeds from cereal grain plants. Not only can the seeds be used but the entire plant may be grazed or can be harvested as a cereal grain hay or green feed. However, the primary purpose of cereal grains is use of the seeds as an energy and/or protein supplement.

As there is far less variation in the quality and nutrient content between cereal grains, values given within this chapter may be used for diet formulation. See Table 16 and Appendix 1 for a summary of nutrient content of commonly used concentrates. 


\begin{tabular}{|c|c|c|c|c|c|c|c|c|c|c|c|c|}
\hline Gentis & ITMT & DE & if' & 8 & 6in & ris & Nig & ite & Min & intm & $\frac{c+1}{y}$ & $\frac{3 y}{m}$ \\
\hline Whole oats & 90 & 3.4 & 11.9 & 12 & 0.07 & 0.32 & 0.14 & 0.5 & 46 & 0.10 & 34 & 5 \\
\hline Hull less oats & 89 & 4.1 & 17.6 & 3 & 0.08 & 0.34 & 0.14 & 0.4 & 31 & 0.21 & 31 & 3 \\
\hline Barley & 88 & 3.7 & 12.6 & 6.0 & 0.07 & 0.35 & 0.15 & 0.54 & 19 & 0.12 & 43 & 6 \\
\hline Corn & 85 & 3.9 & 10.3 & 2.5 & 0.06 & 0.32 & 0.17 & 0.46 & 9 & 0.14 & 23 & 3 \\
\hline Wheat & 88 & 3.9 & 15.9 & 3 & 0.12 & 0.40 & 0.38 & 0.43 & 37 & 0.23 & 42 & 4 \\
\hline Triticale & 90 & 3.8 & 15.7 & 4 & 0.05 & 0.31 & 0.15 & 0.45 & 35 & 0.19 & 36 & 6 \\
\hline Fall rye & 89 & 3.9 & 12.3 & 3 & 0.06 & 0.28 & 0.11 & 0.47 & 32 & 0.04 & 38 & 6 \\
\hline Beet pulp & 82 & 2.6 & 10 & 20 & 0.47 & 0.21 & 0.20 & 1.74 & 54 & 0.15 & 23 & 5 \\
\hline Brewer's yeast & 93 & 3.3 & 47 & $3-7$ & 0.31 & 1.29 & 0.26 & 1.75 & 25 & 0.97 & 40 & 20 \\
\hline Wheat bran & 89 & 3.3 & 17.4 & 11.3 & 0.14 & 1.27 & 0.63 & 1.37 & 134 & 0.57 & 110 & 14.2 \\
\hline Rice bran & 91 & 2.9 & 14 & 13 & 0.1 & 1.7 & 0.97 & 1.89 & 396 & 0.44 & 33 & 12.2 \\
\hline Canola oil & - & 7.3 & - & - & - & - & - & - & - & - & - & - \\
\hline Tallow & - & 7.3 & - & - & - & . & - & & - & - & - & - \\
\hline Ferguremerils & & $\begin{array}{r}2.0- \\
3.0\end{array}$ & $\begin{array}{r}8.0- \\
16\end{array}$ & & $\begin{array}{r}0.3- \\
0.8\end{array}$ & $\begin{array}{r}0.2- \\
0.5\end{array}$ & 0.1 & $\begin{array}{r}0.4- \\
0.6\end{array}$ & 20 & $\begin{array}{l}0.1- \\
0.2^{\mathrm{a}}\end{array}$ & $\begin{array}{r}40 \text { or } \\
60^{b}\end{array}$ & $\begin{array}{r}10 \text { or } \\
25^{\circ}\end{array}$ \\
\hline
\end{tabular}

Table 16. Typical Concentrates in Horse Diets

Except for DM \% all values are on a 100\% DM basis.

a Higher selenium is recommended for last trimester of pregnancy, lactation, for the foal or the horse used in training or performance

${ }^{b}$ Higher zinc is recommended for foals. Some research may suggest that copper at 60 at ppm is better for foals (Pearse et al., 1998)

c Higher copper is recommended for mares during late gestation, foals 2.10 months of age and in creep feeds to reduce incidence of developmental orthopaedic diseases.

Grains are usually fed to highly active horses, or those with special physiological needs such as growing horses, pregnant and lactating mares or breeding stallions.

Grains are not necessary for mature, idle horses unless:

- there are underlying health or teeth problems, or

- horses do not have access to good quality hay or pasture

Grains are fed to horses as a supplement to forage to increase the energy and/or protein content in the diet. 
Grains generally include the cereal grains and the oilseeds, such as soybean, canola and meal. The characteristics of cereal grains include:

- palatable to horses

- nutrient dense

- low in fibre

- high in starch

- low in calcium and most vitamins

Many feed companies produce commercial concentrate grain mixes that are specially formulated for specific needs (i.e. higher protein levels for young, growing horses). These commercial feeds are balanced with added vitamins and minerals; feeding recommendations on the feed label should be followed to ensure proper nutrient intake.

To avoid large variations in blood glucose (which have been implicated in behavioural problems in horses), feed grain in as many meals during the day as possible.

High grain meals often result in grain reaching the cecum and colon instead of being digested and absorbed in the small intestine. When large amounts of grain (starch) reach the hindgut and are fermented, there is a rapid release of volatile fatty acids, which will change the $\mathrm{pH}$ of the hindgut and can cause diarrhoea, colic and/or founder.

Similarly, if a horse overindulges in cereal grain, it can result in diarrhoea, colic, founder or death. To reduce the risk of this occurring:

- feed less grain more frequently throughout the day

- do not feeding forage for one hour before and three hours after feeding grain (only for large grain meals greater than five pounds, otherwise grain and hay can be fed together)

For mature horses, a grain meal should not exceed five pounds. Refer to Figure 5 on page 9 for a diagram on feeding schedule.

If excess grain is fed over a period of time, it will result in:

- hyperactivity or nervousness

- obesity

- founder

It may also increase the risk of developmental orthopaedic diseases in young horses.

Oats

Oats are the traditional feed for horses. This is because oats are:

- a reasonable source of energy (3.5 Mcal DE/kg) and protein (10-13 per cent CP)

- a high source of fat (approximately six per cent) and fibre (10-12 per cent)

In addition, horses find oats a highly palatable feed and there is rarely a problem in feeding oats (fewer instances of colic and founder, moulds and mycotoxins found on oats).

Oats can generally be bought as whole or rolled. Processing oats is generally unnecessary for oats as the hull is soft and easy for horses with good teeth to chew. Steam rolling (crimping) of oats 
offers no advantage compared to dry rolling oats. There is little benefit in digestibility obtained from the processing of oats, and it only offers an advantage to horses with bad teeth.

\section{Corn}

Corn is another grain often fed to horses and is highly palatable. Although not readily grown in Western Canada, it is often included in commercial sweet feeds.

Corn is high energy (approximately $3.35 \mathrm{Mcal}$ of metabolizable energy/kg), but is a poor source of protein (generally lower than 10 per cent CP).

Corn is the second most palatable grain to horses after oats. However, it is far more prone to moulds and mycotoxins than oats, especially if it is processed. Corn that has begun to mould should be disposed of immediately.

Corn is commonly processed to increase the digestibility of the starch and reduce the chance of excess starch reaching the hindgut. It can be fed whole, on the cob, shelled, flaked or cracked. Generally cracked and flaked corn is the most digestible.

Corn has often been referred to as a "hot feed" because horses eating corn have increased energy and their activity levels rise. However this is simply because a gallon of corn contains twice as much energy as a gallon of oats. While corn is moderately higher in energy than oats (per kilogram), it is a lot heavier. Therefore, it is important to feed by weight and not by volume. As such, when using corn in the ration, remember that it is an energy dense feedstuff and make the necessary adjustments.

\section{Barley}

Barley is commonly grown in Alberta, and some will choose barley over oats to feed their horses.

Barley is usually rolled before being fed to horses. Barley is high in energy (approximately 3.7 $\mathrm{Mcal} \mathrm{DE} / \mathrm{kg}$ ) and a reasonable source of protein (10-12 per cent CP).

Because of the high energy content per kilogram and that it is a heavier feed by volume than oats, it too can be considered a "hot feed"; thus, barley should be fed by weight and not volume.

\section{Wheat}

Wheat is higher in energy than corn (3.9 Mcal DE/kg) and protein (11-14 per cent CP). Because of the high energy density and gluten content, problems with over-consumption leading to diarrhoea, colic and founder are more likely than with other grains.

Wheat should not be as more than a third of the grain portion of the diet. Wheat should be processed, as the kernel of wheat is quite hard.

\section{Rye}

Rye should be processed before being fed to horses, and care used to ensure that the grain is free of moulds. Rye is susceptible to a fungus ergot that causes serious problems in livestock, including lameness, gangrene and abortion in mares. Rye is also the least palatable of grains to horses. 
Triticale

Triticale is a hybrid of wheat and rye with $3.45 \mathrm{Mcal}$ of DE/ $\mathrm{kg}$ and up to 15 per cent CP. As triticale, like rye, is susceptible to ergot, a toxic fungus, ensure that the grain is free of moulds. Triticale should also be processed before being fed to horses.

\section{Protein Supplements}

Soybean, canola, and linseed (flax) meals are all good sources of supplemental protein, but are not intended to be fed as the whole concentrate part of the ration.

Of these meals, soybean meal is considered to be the most readily available source of protein. The nutrient content of soybean and canola meal is given in Table 17 Soybean meal is very high in protein (48 per cent CP), has a good amino acid profile and is therefore an ideal protein supplement. Soybean meal is high in lysine, which is the first limiting amino acid in horse diets, and thus can be very important to growing horses.

Canola meal is readily available in Western Canada and has approximately 35-39 per cent CP. It also is a high quality protein and is relatively less expensive than soybean meal.

Linseed or flax meal is added to improve the sheen of the horse's coat. However, the majority of the oil is extracted during solvent processing to make it into meal, meaning that solvent processed linseed meal has no advantage over any other oilseed meal in giving horses a sheen to their coat.

To gain the sheen and fibre contributed by linseed meal, feed mechanically processed linseed meal, which will contain two to three per cent more oil. Similarly, whole or milled flaxseed can also be fed.

\begin{tabular}{|c|c|c|c|}
\hline & emoli & sontien & Hinkibat (fing) \\
\hline Crude protein \% & $40.0^{*} / 40.9$ & $50.2^{*}$ & $36.3^{*} / 38.4$ \\
\hline $\begin{array}{l}\text { Digestible energy } \\
\text { (Mcal/kg) }\end{array}$ & 3.11 & 3.73 & 3.04 \\
\hline Lysine \% & 2.29 & 3.44 & 1.28 \\
\hline Lysine: CP & 0.056 & 0.063 & 0.035 \\
\hline Calcium \% & 1.12 & $0.68^{*}$ & $0.96^{\star} / 0.43$ \\
\hline Phosphorus \% & 1.68 & $0.61^{*}$ & $0.87^{\star} / 0.89$ \\
\hline
\end{tabular}

Table 17. Comparison of nutrient content of soybean canola and linseed meal

Values expressed on a $100 \%$ dry matter basis

-Values based on Alberta feeds

Values as given by the National Research Council (1989).

\section{Other feedstuffs}

\section{Whole Flaxseed}

Whole flaxseed, either ground or milled, can be fed to the horse instead of the flaxseed meal. The benefits of this feed are that the horse gets all of the oil from the seed as well as the higher protein (22 per cent CP). 
Although whole flaxseed can be safely fed to horses, unprocessed flaxseed has typically been boiled prior to feeding to make the hard shell soft and to remove the cyanide found in the seed coat. Horses are able to digest whole flaxseed and the cyanide is removed harmlessly in the horse's stomach.

Boiled, cooked flaxseed produces a thick liquid mash that has traditionally been effective as a laxative (due to the water in the mash) and the oils in the flax are beneficial for a shiny coat. Alternatively, milled or ground flaxseed is a good choice, but will spoil more rapidly. Careful storage is required.

\section{Beet Pulp}

Beet pulp is the pulp remaining after sugar is taken from the sugar beet. Beet pulp is very fibrous and has a similar nutrient profile to high quality grass hay, with:

- $\mathrm{mcal} / \mathrm{kg} \mathrm{DE}$

- ten per cent CP

- higher calcium

- lower phosphorus

As a roughage, it is highly digestible compared to long-stemmed hay and is a good, safe source of energy for horses that need extra energy or to put on weight. Although it is higher in calcium compared to grains, it provides a good ratio of calcium to phosphorus of 2:1, similar to hay.

Beet pulp does not necessarily need to be soaked before feeding. Horses that are used to eating it dry should not have problems with it. For horses that have a tendency to choke on pelleted feed, it may be better to soak the beet pulp before feeding. Beet pulp can be soaked the night before for the following day's feed, or in as little as one hour before feeding.

\section{Citrus Pulp}

Citrus pulps are similar to beet pulps as they are the pulp (peel, pith and seed) remaining from citrus fruits after the juices and sugars are extracted. The pulp is dried and pelleted after the addition of limestone to remove the acid. These pulps have a similar nutrient profile to beet pulp and other roughages. They provide energy to the horse in the form of fibre.

\section{Vegetable Oil}

Vegetable oil can be added to a horse's diet to provide additional energy. Vegetable oil is:

- highly digestible

- very high in energy (100 per cent fat)

- 2.25 times more energy dense than carbohydrates

Since there are no carbohydrates in vegetable oil, the problems associated with large amounts of sugars and starches in the diet, such as overactivity, or digestive upsets such as colic, will be avoided.

Canola oil is the best choice, as it contains a good profile of omega- 3 and omega- 6 fatty acids, but corn oil, sunflower oil and soybean oil will work. The horse does not digest mineral oil, and the horse will not gain any nutrition from it. 


\section{Fish Oil}

Fish oil is an excellent source of omega-3 fatty acids but it is expensive and some horses find it unpalatable.

\section{Stabilized Tallow}

Tallow can be added as an energy supplement (approximately $8.8 \mathrm{Mcal} \mathrm{DE} / \mathrm{kg}$ ), for dust control or as a coat conditioner. Like any change in diet, tallow should be added slowly to the diet and storage time should be limited as much as possible to avoid the tallow from becoming rancid.

\section{Wheat Bran}

Wheat bran is the coarse outer coating of wheat that is removed during the milling process and is commonly used to add bulk and fibre to the diet.

However, wheat bran has roughly the same amount of fibre as oats, and is not as good a fibre source as roughages such as beet pulp. As bran is very high in phosphorus, proper attention should be paid to ensure that the calcium to phosphorus ratio in the diet is still higher than 1:1 (phosphorus levels should never exceed calcium levels).

Bran itself is an ineffective laxative for horses; however, a bran mash can serve to provide a horse with extra water, feed, or other supplements (i.e. salt, minerals, or medicines) as needed.

\section{Rice Bran}

This is a newer supplement that is fed to horses that have problems gaining weight.

Rice bran is quite high in fat (20 per cent) and a good source of essential fatty acids. It is very expensive, so if a source of fat is required, canola oil (100 per cent fat) is a more economical option.

Rice bran, like wheat bran, is also very high in phosphorus. As such, some manufacturers will sell it with added calcium to ensure that the proper calcium to phosphorus ratio is maintained. Also, it is usually stabilized, meaning that due to the high fat content it is processed to prolong the shelf life of the product.

\section{Molasses}

Molasses is sometimes used to improve the palatability of feed and help to bind ingredients together. However, due to its high sugar content, it can be used an energy supplement as well.

Molasses is very high in sugar (50-60 per cent), low in protein (three per cent) and high in mineral content (potassium, chloride, calcium and sulphates).

Molasses is most often used to:

- increase the palatability of the ration

- reduce dust

- aid in mixing

Because of its high mineral content, a horse should have no more than $0.45 \mathrm{~kg}(1 \mathrm{lb})$ per day of molasses. 


\section{Dried Brewer's Grains}

This is a by-product of the brewing industry, and mainly composed of the leftovers after the starches have been removed from barley. It is high in protein and fibre and low in sugars. It may be safe and useful in horse rations.

\section{Distiller's Grains}

Similar to brewer's grains, this is the leftover from grains that are used in the distilling process. The sugars in the grains have been removed and fermented to produce alcohol, and what remains is a feed with relatively high protein and fibre. It is also a safe and useful feed for horses.

\section{Brewer's Dried Yeast}

Brewer's yeast is an excellent source of protein (approximately 20 per cent CP) and an excellent source of B vitamins. It may be beneficial in a diet for an aged or high-performance horse or horses in poor condition. Brewer's yeast should not comprise more than one per cent of the ration.

\section{Pulse Crop Proteins (Beans and Peas)}

Beans and peas are the seeds of legumes and are commonly called pulse crops. Pulse crop proteins are similar in energy content to cereal grains, but provide two to three times more protein of good quality.

However, some pulse crops (typically the older varieties) may contain anti-nutritional factors that may reduce palatability of the feed and decrease the amount horses will eat.

Heat processing destroys many of these anti-nutritional factors so they can be easily fed to horses.

\section{Animal-source Protein Supplements}

Very few animal-based proteins are fed to horses because they have poor palatability and are more prone to spoilage than most grains.

Most animal-based feed products used are:

- milk or milk products

- inedible or surplus meat from meat-packing or rendering plants

- by-products of the fish, poultry or egg industry

Milk products and fishmeal are used in creep feeds and as milk replacers for foals because they are high quality proteins. However, soybean and canola meal are nearly as good a protein, and tend to be cheaper.

\section{Single-celled Proteins}

Single-celled proteins are derived from single-cell organisms such as yeasts, bacteria and algae and contain large amounts of protein. However, there are many problems associated with their production. 
Some equine supplements contain a single cell protein from an algae called spirulina, which is thought by many horse people to be beneficial. However, research has shown neither benefit nor harm from feeding single cell proteins to horses.

If given to horses, single cell proteins should not comprise greater than two per cent of the diet.

\section{Mineral Supplements}

Mineral supplements may be added to the diet to ensure horses are receiving adequate minerals in the appropriate ratios.

It is not usually recommended that individual minerals be supplemented to horses.

However, calcium: phosphorus supplements should be added to diets that are mainly based on hay, as hay has lower phosphorus levels. In this case a calcium: phosphorus supplement providing a 1:1 ratio is recommended. This is especially important for young horses and pregnant and lactating mares.

Commercial mineral supplements generally contain:

- 15-20 per cent calcium

- 10-20 per cent phosphorus

- 25 per cent salt

- 25 per cent trace minerals

Most commercial mineral supplements can be fed at 25-100 g per day following the directions on the product label.

Loose mineral supplements can be fed free choice to mature horses with no problems. As some horses may over-or under-consume minerals they can also be mixed with loose salt (two parts mineral to one part salt) to ensure consistent intake.

As foals and weanlings may not eat minerals free choice, a mineral supplement for these young horses should be added directly to the ration. To avoid "sorting" of the mineral supplement from the rest of the ration, molasses or oil can be added to bind the mineral supplement to the feed.

\section{Commercial Feeds}

There are many different products on the market today, and it is sometimes hard to understand:

- what these feeds are

- the differences among them

- how to feed them and when they are to be fed

The different feed types can be classified into different categories as outlined below.

\section{Traditional Plain Grains or Mixed Grains}

A bag of plain oats or barley, or a mix of oats and barley fits into this category.

The grain mix is not fortified with added minerals and vitamins. Additional protein, mineral and vitamin supplementation will be needed for growing horses or pregnant and lactating mares. 


\section{Fortified Grain Mixes}

This category encompasses the traditional sweet feeds and "complete" pelleted feeds. It is typically a grain mix with added protein, vitamins and minerals that is formulated for a specific type of horse. Sweet feed is a grain/protein/mineral/vitamin mix with added molasses to bind all of these components together. These mixes can also be pelleted or extruded.

\section{Fat-added Grain Mixes}

This category has been added recently due to the increased use of oil in horse diets.

Fat can be beneficial as an energy source because it replaces some of the starchy grains reducing grain-associated digestive upsets.

In these feeds, the fat source may be oil such as canola or soybean oil or a high fat feed such as rice bran or flaxseed.

For performance horses, added fat can also improve behaviour and athletic performance.

These grain mixes have a higher crude fat (5-12 per cent) than traditional horse feeds. The feeds were initially formulated for performance horses; as such, improvements and adjustments are still being made to produce fat-added feeds with appropriate concentrations of energy, protein and mineral and vitamins for use in other types of horses such as weanlings, lactating mares and older horses.

\section{Fat and Fibre-added Grain Mixes}

Adding fibre sources to the grain mix is the most recent trend in commercial feeds. The amount of crude fibre in these feeds is typically 8-14 per cent.

Some horses (like overweight horses, those prone to founder or older horses) are sensitive to starches and sugars as an energy source. These new feeds have been developed to provide more of the calories in the feed as fibre sources, such as beet pulp or soybean hulls, making them "safer" for these horses as compared to regular grain mixes.

More research is needed to determine a safe level of fat and fibre inclusion for growing horses.

\section{Complete Feeds}

Some feeds are being formulated as the only feed for the horse to replace both the grain AND hay component of the diet. These feeds will have a substantial fibre component, and are typically over 18 per cent crude fibre.

Some of these complete feeds have been specifically developed for the older horse that has trouble digesting fibre in the form of long hay, and for older horses having difficulties maintaining body condition. These feeds can also be advantageous when travelling, as they are convenient to feed, there is less waste and they are less bulky than hay. 


\section{Slowing Down Grain/Concentrate Consumption}

To slow feed consumption down:

- feed small amounts often

- spread the grain over a large surface

- use a feeder with many compartments in it

- put large, smooth rocks in the feeder

- feed anxious horses first and always feed horses in the same pattern

- mix hay with the grain or feed grain on top of hay 


\section{FEEDING MANAGEMENT}

\section{FEEDING THE MATURE, IDLE HORSE: MAINTENANCE}

A mature, idle horse can eat between $1.5-2.5$ per cent of its body weight in forage per day.

Good quality forage should form the basis of the maintenance horse's diet. If low quality forage is supplied, a supplement in the form of grains and possibly a protein supplement may need to be added. If the horse only eats forages, an appropriate mineral supplement containing phosphorus should be fed.

Similarly, as Alberta forages may be low in copper, zinc and manganese (see Table 10) having a trace-mineralized salt accessible is important. In place of this, a total vitamin/mineral premix can be fed to ensure an adequate intake of calcium, phosphorus and trace minerals, either mixed with loose salt (two parts mineral mix: one part salt), or fed free choice along with an appropriate salt block.

Some horses are easy keepers and some have trouble keeping weight on. If there are horses with unique nutritional needs, it is a good idea to segregate them to allow for individual feeding and management.

A mature, idle horse on a good pasture will tend to overeat, and may develop metabolic problems such as fatness and founder.

Horses can be turned out on pasture in the morning or evening and then brought into a paddock or sacrifice area (an area where the pasture quality will be sacrificed), to limit their pasture intake. Pastured horses will require mineral supplementation, in the form of a vitamin/mineral supplement and salt. Trace-mineralized salt is considered the minimum supplementation; however, a complete salt and mineral supplement including calcium and phosphorus is preferred.

A source of potable water should also be available to the horse at all times.

\section{NUTRITIONAL MANAGEMENT OF THE BROODMARE}

Proper nutritional management of the broodmare is essential for the health of both mare and foal.

There are large demands on a mare's energy, fat, protein and mineral (bone) reserves during the last trimester of pregnancy when the foal is gaining almost a pound a day, and during lactation. Furthermore, a mare is more likely to conceive when she has adequate energy and fat reserves to sustain the pregnancy.

Good nutrition is also important to optimize milk production and milk nutrient content, which in turn optimizes foal growth and health.

It is vital the broodmare be kept in good body condition throughout gestation and lactation, as mares are frequently re-bred soon after foaling. With the nutrient demands on a lactating mare being very high, it is much easier to maintain body condition of the broodmare than to let her lose condition and try to regain it later. 


\section{Appropriate Body Condition for Breeding}

If a mare is too thin, she may not cycle, or have erratic cycles. Mares that are moderately fleshy (body condition score 6-7) will probably:

- cycle earlier in the year

- have fewer cycles before conception

- have a higher pregnancy rate

- be more likely to retain the pregnancy

A mare should be in a body condition of 5 or greater for optimal breeding and should be fed to maintain body condition or to gain weight. When mares are being group fed, it is important to observe all the mares individually and separate those that are in body condition of less than 5 , and to give them supplemental hay and grain (see Table 20 on page 77 ).

\section{When to Re-breed}

The mare will exhibit a foal heat about nine days after the birth of the foal. Re-breeding on this heat is not recommended, as the uterus has not had a chance to return to normal. Breeding on this heat may result in lower conception rates and increased early embryonic losses.

It is best to wait until the subsequent heat to re-breed the mare. If the foal heat occurs at least 14 days after parturition, the mare can be re-bred.

\section{General Feeding Guidelines for Broodmares}

The concern for pregnant and lactating mares is meeting the required level of energy, protein, calcium and phosphorus. The trace minerals iodine, copper, zinc and manganese and vitamins A, D, and E may also be important to optimize reproductive performance and ensure proper foal development.

High quality forages, such as an alfalfa/grass hay mix, should form the basis for feeding programs for broodmares. Good quality pasture may be able to replace some or all of the hay fed. However, when pasture is limited and especially during winter, mares will need to be supplemented with hay. Supplementation with grains or commercial grain supplements may be necessary when energy and protein needs of the mare increase during lactation or late gestation.

A suitable mineral/vitamin supplement can meet additional calcium, phosphorus and trace mineral and vitamin needs.

If a commercial grain supplement is fed, this has the advantage of being fortified with minerals and vitamins, and as long as it is being fed at amounts recommended on the package, only additional salt should be made available.

If only grain is being fed, such as oats, a mineral supplement supplying calcium, phosphorus, and the trace minerals will be required.

It is important, especially with grain feeding, to gradually change the diet over a period of one to two weeks while introducing the grain. It is advisable to not feed more than five pounds of grain in a single feeding (break it up into two or more feedings). 


\section{Pregnancy}

A mare's gestation or pregnancy is approximately 340 days (11 months). This can vary by two weeks.

\section{Early Pregnancy}

During the first two trimesters of pregnancy (up to eight months) the foal is not gaining much weight (the foal weight averages 20 pounds at the end the second trimester) and the mare requires little extra nutrition beyond maintenance.

Even so, it is important that her diet meets requirements for energy, protein, minerals and vitamins, and that she is on a good quality feed to maintain her health. Sample rations for an early pregnant mare are included in Table 19.

If the mare was not in a body condition of 5 or better at mating, she will need grain supplementation to improve her condition during her pregnancy (see the section titled "What to do with mares in poor body condition"). If the mare is nursing a foal, she should be managed as a lactating mare.

\section{Late Pregnancy}

During the last three months of gestation, the foal is growing rapidly and gaining almost one pound per day. This means that:

- energy and protein needs are increased for tissue growth

- calcium and phosphorus (among other minerals) needs are increased for bone growth

If the mare's diet is not adequate in minerals, she will mobilize minerals from her bones which can cause a loss in bone density. It is also important that the diet is not deficient in vitamin A, as a lack of vitamin A may cause abortion.

Although a diet based on good quality hay and grain should supply adequate vitamin levels, a vitamin premix can be fed when feeding feeds of questionable vitamin levels. Fresh pasture is very rich in vitamins for the pregnant mare. If the mare is being fed a commercial grain supplement, the label will indicate vitamin levels.

The energy and protein content of the mare's ration should be increased by 20 per cent during late pregnancy (see Table 18 on page 76). The protein requirements of a mare jump to 11 per cent, which may not be met if the mare is solely on grass hay. If this is the case, a complete ration with a protein supplement such as soybean meal or a commercial 16 per cent horse feed can be fed along with the hay in order to meet the mare's overall nutrient requirements. Sample rations are included in Table 19 on page 77.

If good quality alfalfa or alfalfa/grass hay is being fed, the mare's requirements can be met by increasing the quantity of hay being fed. However, there are a few advantages to adding grain instead of increasing hay:

- The mare will have less room in her digestive tract in late gestation and may not be able to consume the extra hay needed to meet her increased requirements.

- A mineral premix can easily be fed with the grain to ensure that her calcium, phosphorus and trace mineral intake is adequate. 
- Alberta forages and grains are deficient in the trace minerals zinc and copper, which are important minerals for fetal bone development. Studies have shown (Pearse et al., 1998) that supplementing copper to the mare's diet during pregnancy is beneficial to reducing the incidence of bone developmental problems in the foal, where supplementing the foal after birth is less effective.

- Introducing grain in late gestation will get the mare accustomed to grain feeding, which may be necessary during lactation. Ideally, a mare's routine (from feeding to turnout) should not be changed.

\section{Lactation}

During the first 24 hours after birth, the mare produces an energy and nutrient dense milk called colostrum. Colostrum is essential for the foal as it is concentrated in energy, protein, minerals and vitamins, and most importantly, antibodies that will, in part, give the foal immunity for the next three to five months.

It is only during the first 24 hours after birth that the foal's digestive system remains "open" to allow absorption of colostral antibodies. It is critical that the foal receive colostrums within the first few hours after birth and frequently thereafter.

Furthermore, the foal needs access to nourishment immediately after birth so that it will get the energy and water that it needs.

\section{Milk Production}

The mare's milk contains approximately 90 per cent water and $475 \mathrm{kcal}$ of gross energy per kilogram, 12.2 per cent protein and six per cent lactose (sugar).

Although some mares can produce $24 \mathrm{~kg}$ of milk per day, milk production is around:

- $15 \mathrm{~kg}$ (33 lbs) per day for the first few months

- $17 \mathrm{~kg}(38 \mathrm{lbs})$ when it peaks at the third month of lactation

By the fourth month milk production will start to decline when the foal starts to eat other feeds (creep feeds) (Figure 8).

According to the calculations, $15 \mathrm{~kg}$ of milk $\times 475 \mathrm{kcal} / \mathrm{kg} \times$ by the 60 per cent efficiency with which a mare can transform her dietary energy into gross energy of milk, equals the 11.9 Mcal of energy per day needed to produce milk.

The average $500 \mathrm{~kg}$ mare needs $16.4 \mathrm{Mcal}$ per day just for her own energy requirements, so added to lactation requirements of $11.9 \mathrm{Mcal}$ per day it is easy to see that the mare's nutrient requirements will increase dramatically to almost 100 per cent over her maintenance requirements (see Table 18 on page 76 ).

Her protein requirement will also increase proportionally to energy, and mineral requirements will increase so that foal can build tissue, muscles and strong bones. This requires that a lactating mare be fed not only a good quality hay, but also grain and mineral supplementation (see Table 19 on page 77 ).

If a mare is not fed adequately during lactation, she will mobilize body reserves to produce milk. If severely restricted, the health and growth of her foal will suffer. 
It is even more important to meet her increased demand for energy, protein calcium and phosphorus if she is to be rebred after foaling.

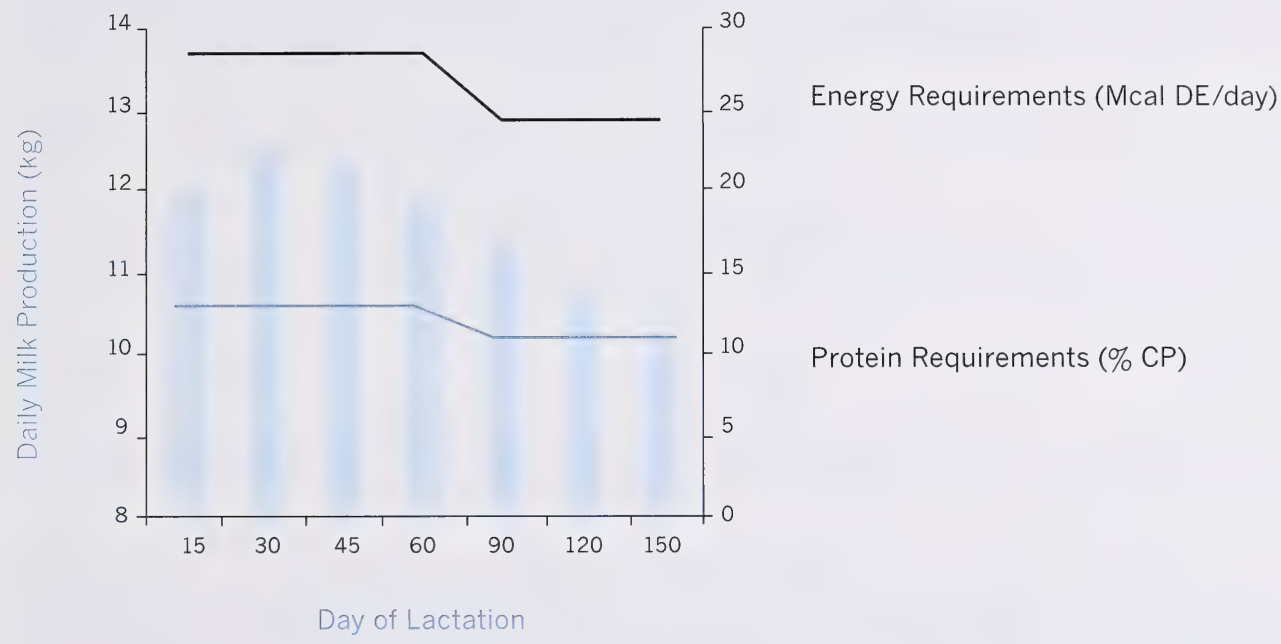

Figure 8. Daily milk production, energy and protein requirements for lactation.

By the time a foal is three months of age, milk will only provide 50 per cent of its nutrient requirements, and by six months of age, only 20 per cent. The foal is still rapidly growing, but milk production can only provide a part of its nutritional requirements. The rest needs to be provided by feed.

From three months of age to weaning, a good creep feed should be available to the foal, in a specialized feed bin that only the foal can access. If a mare is having difficulty producing enough milk for the foal because of her poor body condition, the foal should be started on creep feed in its second month.

During the fourth month of lactation, the mare will require less energy, and her grain ration can gradually be reduced by half provided that she is in good body condition and does not need to gain weight (Table 19). Once the foal is weaned, the mare can be managed as an early pregnant mare once again. Ideally foals should be weaned at four months of age.

\section{Water Consumption During Lactation}

On average, a mare will produce $15 \mathrm{~kg}$ of milk per day. This is mainly composed of water, meaning she needs to drink an extra $15 \mathrm{~kg}$ of water a day (this is double her water intake) to meet lactation requirements. A mare should have a reliable source of potable water (see water section) at all times, as they are the most sensitive of all horses to water quality.

\section{What to Do with Mares in Poor Body Condition}

Optimally, a mare should be in fleshy body condition (6-7 in body condition scoring), and should be fed to maintain this condition. But she should always be fed to gain weight if she loses condition due to circumstances such as a harsh winter or loss of condition during lactation. 
To move up a body condition score, $20 \mathrm{~kg}(45 \mathrm{lbs})$ of gain are needed. This translates into $22 \mathrm{Mcal}$ of extra digestible energy for each $\mathrm{kg}$ of gain required (10 Mcal for every pound). Therefore, to move up one body condition score, a mare would have to eat $127 \mathrm{~kg}$ of oats! As this cannot be achieved safely in a short period of time feed should be gradually increased to over a period of 60 to 120 days (see Table 20).

The best time to improve the mare's body condition is from early gestation up to eight months. This usually occurs in the fall, when weather is mild and the mare can gain weight more easily.

When feeding grain, increase the amount of grain in the ration over a period of two weeks, and break it up into smaller, more frequent meals. It is very difficult to put weight on a lactating mare because she will put all of her energy into milk production, resulting in grain feeding over and above what she can eat.

Such high levels of grain need to be fed with care due to the risk of colic or founder. Therefore, it is most important that the mare start lactation in good fleshy body condition. See the Alberta Agriculture and Rural Development's factsheet, Feeding the Broodmare (Agdex 460/50-6), for detailed information on how to improve body condition.

\begin{tabular}{|c|c|c|c|c|c|}
\hline Awhonal & $\langle$ Whi in & 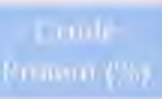 & 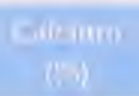 & $\begin{array}{l}\text { Olimplower } \\
\text { ysy }\end{array}$ & $\begin{array}{l}\text { Yetamin } \\
\text { (1) } 1 \text { (4) }\end{array}$ \\
\hline Maintenance & 16.7 & 8.0 & 0.30 & 0.20 & 1870 \\
\hline Early-mid Gestation & 17.5 & 9.0 & 0.30 & 0.20 & 1870 \\
\hline Late gestation & 20.2 & 11.0 & 0.45 & 0.35 & 3740 \\
\hline $\begin{array}{l}\text { Early lactation } \\
\text { (1-3 months) }\end{array}$ & 31.7 & 13.5 & 0.55 & 0.35 & 3740 \\
\hline $\begin{array}{l}\text { Late lactation } \\
\text { (4-6 months) }\end{array}$ & 28.3 & 11.0 & 0.40 & 0.25 & 3080 \\
\hline
\end{tabular}

Table 18. Example of daily nutrient requirements for broodmares weighing $500 \mathrm{~kg}$

Modified from Alberta Agriculture and Rural Development's factsheet Feeding the Broodmare, (460/50.6). 


\begin{tabular}{|c|c|c|c|c|c|c|c|}
\hline Iminul & 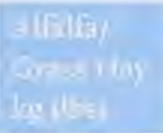 & 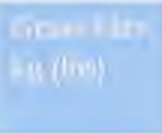 & 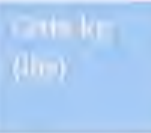 & 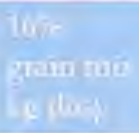 & 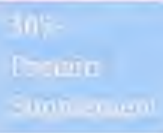 & $\begin{array}{c}\text { (6) } \\
\text { moments }\end{array}$ & 1 \\
\hline \multicolumn{8}{|c|}{ 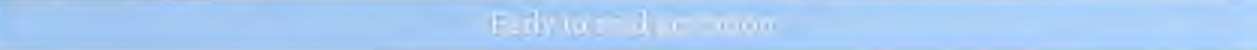 } \\
\hline Ration A & $9(20)$ & - & - & - & - & $28 \mathrm{~g}$ & Yes \\
\hline Ration B & $7.25(16)$ & - & $1.4(3)$ & - & - & $28 \mathrm{~g}$ & Yes \\
\hline Ration C & - & $10(22)$ & - & - & - & $28 \mathrm{~g}$ & Yes \\
\hline \multicolumn{8}{|c|}{ 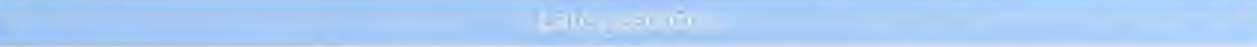 } \\
\hline Ration A & $11(24)$ & - & - & - & - & $56 \mathrm{~g}$ & Yes \\
\hline Ration B & $8.2(18)$ & - & $1.8(4)$ & - & - & $56 \mathrm{~g}$ & Yes \\
\hline Ration C & - & $8.2(18)$ & - & $1.8(4)$ & - & - & Yes \\
\hline \multicolumn{8}{|c|}{ 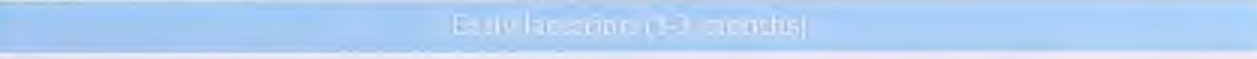 } \\
\hline Ration A & $9(20)$ & - & $3.5-4(8-9)$ & - & - & $64 \mathrm{~g}$ & Yes \\
\hline Ration B & - & $9(20)$ & $3.2(7)$ & - & $1.1(2.5)$ & - & Yes \\
\hline Ration C & - & $9(20)$ & - & $3.5(8)$ & - & - & Yes \\
\hline \multicolumn{8}{|c|}{ 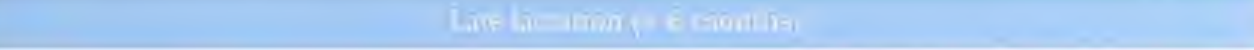 } \\
\hline Ration A & $9(20)$ & - & $1.5-2(4-4.5)$ & - & - & $64 \mathrm{~g}$ & Yes \\
\hline Ration B & - & $9(20)$ & $1.6(3.5)$ & - & $0.5(1.25)$ & - & Yes \\
\hline Ration C & - & $9(20)$ & - & $1.8(4)$ & - & - & Yes \\
\hline
\end{tabular}

Table 19. Examples of feeding programs for broodmares

From Alberta Agriculture and Rural Development's factsheet Feeding the Broodmare (Agdex 460/50-6).

\begin{tabular}{|c|c|c|c|c|c|}
\hline \multicolumn{3}{|c|}{ 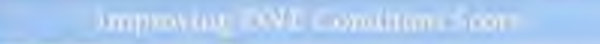 } & \multicolumn{3}{|c|}{ 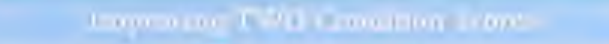 } \\
\hline 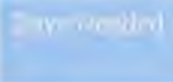 & 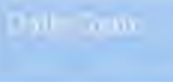 & 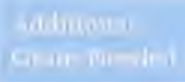 & $11+x+5$ & $1011,7=6$ & 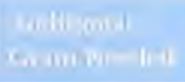 \\
\hline 60 & $\begin{array}{l}0.75 \mathrm{lbs} / \text { day } \\
\text { (0.35 kg/day) }\end{array}$ & $\begin{array}{l}4.5 \mathrm{lbs} / \text { day } \\
\text { (2.0 kg/day) }\end{array}$ & 90 & $\begin{array}{l}1.00 \mathrm{lbs} / \text { day } \\
(0.45 \mathrm{~kg} / \text { day })\end{array}$ & $\begin{array}{l}6.0 \mathrm{lbs} / \text { day } \\
\text { (2.8 kg/day) }\end{array}$ \\
\hline 90 & $\begin{array}{l}0.50 \mathrm{lbs} / \text { day } \\
(0.22 \mathrm{~kg} / \text { day })\end{array}$ & $\begin{array}{l}3.0 \mathrm{lbs} / \text { day } \\
(1.4 \mathrm{~kg} / \text { day })\end{array}$ & 120 & $\begin{array}{l}0.75 \mathrm{lbs} / \text { day } \\
(0.35 \mathrm{~kg} / \text { day) }\end{array}$ & $\begin{array}{l}4.5 \mathrm{lbs} / \text { day } \\
(2.0 \mathrm{~kg} / \text { day })\end{array}$ \\
\hline 120 & $\begin{array}{l}0.40 \mathrm{lbs} / \text { day } \\
(0.2 \mathrm{~kg} / \text { day })\end{array}$ & $\begin{array}{l}2.3 \mathrm{lbs} / \text { day } \\
(1 \mathrm{~kg} / \text { day })\end{array}$ & 150 & $\begin{array}{l}0.60 \mathrm{lbs} / \text { day } \\
(0.30 \mathrm{~kg} / \text { day })\end{array}$ & $\begin{array}{l}3.5 \mathrm{lbs} / \text { day } \\
\text { (1.6 kg/day) }\end{array}$ \\
\hline
\end{tabular}

Table 20. Time and additional grain required to improve body condition score by 1 or 2 levels

From Alberta Agriculture and Rural Development's factsheet Feeding the Broodmare (Agdex 460/50-6). 


\section{FEEDING MANAGEMENT OF THE STALLION}

A stallion is expected to perform well and produce excellent quality semen throughout the short breeding season. His performance will be affected by his:

- health

- stress level

- nutrition

Production of sperm is definitely a large factor in the fertility of the stallion, as is the concentration of sperm in semen used for breeding. Sperm takes 60 days to become mature, so management before the breeding season is a key factor. Any stress that the stallion is subjected to before breeding season will have a lasting impact on the number of mature sperm that are available 60 days later.

Assessment of body condition is an ideal way to monitor the health and nutritional status of the stallion.

- The stallion is at his peak reproductive performance when he is in a good to moderately fleshy body condition score (5-6). The ribs should not be seen, but easily be felt.

- A stallion that scores at a body condition score of less than 3 will likely not have enough energy to sustain his breeding performance throughout the season.

- Similarly, he should not be allowed to become fat (score of 8 or 9). Overweight stallions may have problems with reduced libido, and certainly the extra weight can cause strain on the legs and can lead to health problems such as laminitis.

- Some stallions may lose weight over the breeding season, so ensuring a body condition score of 6-7 going into the breeding season for these stallions will mean that their performance is not compromised.

For more information on body condition scoring, refer to the Alberta Agriculture and Rural Development's factsheet Body Condition Scoring Your Horse (Agdex 460/20-1).

Increasing the energy content of the diet is important for the stallion. He will expend a great deal of energy during the breeding season due to the physical and psychological responses associated with breeding activity. Any increased protein, vitamin and mineral needs will most likely be met as increased energy is added to the diet.

Good quality forage, as pasture or either high quality grass hay or mixed alfalfa/grass hay, should form the basis of the diet for the stallion. The extra energy that he needs can be supplemented through the addition of grain to the ration. Vegetable oil can also be used to replace some of the grain.

As some amino acids, especially methionine, can factor into the production of sperm, ensure that the stallion is fed a source of high quality protein such as is found in good forage, or oats and barley. Corn is a poor source of methionine. 
The vitamin and mineral needs of the stallion should also be met to ensure the stallion is performing to his best capacity. He should be fed a well-balanced vitamin/mineral premix containing:

- a 1:1 calcium: phosphorus ratio

- the trace minerals, copper, zinc, manganese and selenium as these tend to be deficient in Alberta forages

Otherwise, a 1:1 calcium phosphorus supplement can be fed along with a trace-mineralized salt. Salt should always be provided free-choice at all times along with a source of clean, potable water.

Vitamin requirements are easily met if the stallion has some access to pasture during the summer or fresh hay (under one year old). The important vitamins $\mathrm{A}$ and $\mathrm{E}$ are plentiful in green grass; however, they are reduced during the storage of hay. Hay less than one year old will have high enough levels of vitamin A and $\mathrm{E}$ to meet their requirements.

A simple, balanced vitamin supplement may be given if the stallion does not have access to proper pasture.

If the stallion is being fed a balanced diet that meets his requirements for energy, protein, vitamins and minerals, any extra supplementation will not enhance fertility. Some stallions are naturally more fertile than others, while some will always have reproductive problems.

To meet nutritional needs of a stallion, a simple, basic, well-balanced diet should be offered with all of the energy, protein, minerals and vitamins to meet his requirements (see Table 21). This should be based on good quality forage, with basic supplementation of:

- energy as grain

- the minerals calcium and phosphorus

- trace-mineralized salt

- potable water

The requirements of the stallion will be similar to the mature, idle horse at maintenance. However, if the horse is being ridden or shown regularly, then his requirements will increase to those of a performance horse.

\begin{tabular}{|c|c|c|c|c|c|}
\hline & 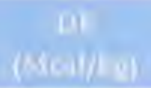 & nit: & $x^{2}$ terim & Mlin tyonom & $\sqrt{1+1}$ \\
\hline $\begin{array}{l}\text { Off-season, } \\
\text { idle stallion }\end{array}$ & 18.2 & 8.0 & 0.3 & 0.2 & 1,830 \\
\hline $\begin{array}{l}\text { Breeding } \\
\text { season } \\
\text { (light work) }\end{array}$ & 20.0 & 10.0 & 0.35 & 0.25 & 2,640 \\
\hline $\begin{array}{l}\text { Breeding } \\
\text { season } \\
\text { (moderate work) }\end{array}$ & 21.8 & 10.5 & 0.35 & 0.25 & 2,640 \\
\hline
\end{tabular}

Table 21. Requirements of the stallion weighing $500 \mathrm{~kg}$

*on a $100 \%$ dry matter basis

From Alberta Agriculture and Rural Development's factsheet Feeding the Stallion (Agdex 460/50-3). 


\section{Feeding Programs for the Stallion}

During the non-breeding season the stallion can be managed as a maintenance horse (unless he is being ridden and then he should be managed as a performance or working horse). He will require 1.5 to 2 per cent of his body weight in good to high quality hay. Some of the hay may be replaced with grain if desired and examples of feeding programs are listed in Table 22.

If the stallion needs to gain body condition before the breeding season, adding an extra three to four pounds of grain daily to one of the suggested feeding programs will improve the body condition score by one point in three months.

Grain will need to be supplemented if the hay quality is poor. Calcium and phosphorus should be added to the diet to meet the stallion's requirements and a trace-mineralized salt should be available at all times, even when on pasture. If the hay quality is questionable, a complete simple vitamin/mineral premix can be offered to meet requirements.

During the breeding season, the amount of increased energy the stallion needs will depend on the:

- amount he will be used

- degree of physical and psychological response to breeding

As mentioned above, a stallion should not be allowed to become fat. His body condition should be assessed frequently and may result in adjustments to his feeding program.

Similarly to the off-season, high quality forage, fed at a minimum of one per cent of body weight, should form the basis of the stallion's diet. Good quality pasture can also supply all of the stallion's requirements for energy and protein and is an excellent source of vitamins.

To increase the energy in the diet during the breeding season, energy dense grains can be added, and vegetable oil can also replace some of the grain (see Table 22 for suggested feeding programs). The grain portion of the diet should be reduced if the stallion becomes too highspirited or gains too much weight.

\begin{tabular}{|c|c|c|c|c|c|c|}
\hline$f(x)=$ & 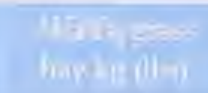 & 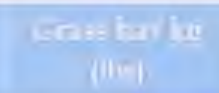 & $\begin{array}{c}\text { cate } 58 \\
(1 / i)\end{array}$ & $\begin{array}{c}y=-2 a b l e \\
m i n\end{array}$ & 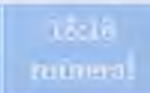 & $7 \mathrm{M}^{3}$ sail \\
\hline \multicolumn{7}{|c|}{ 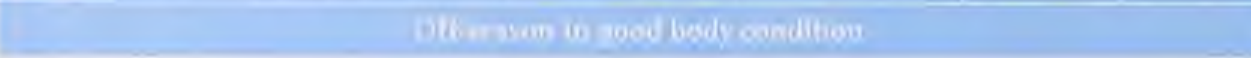 } \\
\hline Ration A & $9-10(20-22)$ & - & - & - & $28 \mathrm{~g}$ & Yes \\
\hline Ration B & $7.2-8.2(16-18)$ & - & $1.4(3)$ & - & $28 \mathrm{~g}$ & Yes \\
\hline Ration C & - & $10-11.2(22-25)$ & - & - & $28 \mathrm{~g}$ & Yes \\
\hline \multicolumn{7}{|c|}{$11-\operatorname{lng} 8-11$} \\
\hline Ration A & $9(20)$ & - & $1.8(4)$ & - & $28 \mathrm{~g}$ & Yes \\
\hline Ration B & - & $8.2(18)$ & $2.75(6)$ & - & $28 \mathrm{~g}$ & Yes \\
\hline Ration C & - & $8.2(18)$ & $2.0(4.5)$ & 1 cup & $28 \mathrm{~g}$ & Yes \\
\hline
\end{tabular}




\section{FEEDING MANAGEMENT OF THE GROWING HORSE}

The proper growth and development of a foal is very important to those raising young horses. Although the genetic potential of the horse is already decided, nutrition plays a significant role in producing a strong, sound horse capable of reaching its genetic potential. The foal's diet should not only contain the adequate amounts of energy, protein, minerals and vitamins for its needs, but should also be well balanced without too much excess.

The proper way to feed young horses to achieve optimal growth is an area where there are many misconceptions and concerns. Questions arise whether to feed low protein or reduce energy to limit growth and how much to supplement with minerals. It is important to understand that:

- the young growing horse has high nutrient requirements

- high quality forages, grains or concentrates should be fed to provide a nutrient-rich diet

- the quality of protein is very important

The protein sources should be high in lysine, an amino acid that is important for growth. As the young horse's digestive system does not allow much room for bulky, low quality feeds, the younger the horse, the more nutrient-rich the feed needs to be.

For complete details on how to feed young horses, refer to the Alberta Agriculture and Rural Development's factsheet Feeding Young Horses for Sound Growth (Agdex 460/50-2).

\section{Developmental Bone Diseases}

Optimal growth in young horses means reducing the incidence of or avoiding bone and joint disorders, which are called developmental orthopaedic diseases (DOD).

Although there is a genetic factor involved that predisposes horses to the development of these diseases, nutrition can also play a role. Other contributing factors include:

- trauma

- rapid growth

- too much or too little exercise

Some of the disorders seen in DOD are:

- epiphysitis

- osteochondrosis

- angular limb deformities

- contracted tendons

- wobbler's syndrome

Symptoms of DOD are enlargements and deformities of the ankles, knees and hocks.

Horses are born with bones that are still rapidly growing and are not "closed." As bones become "closed," the process involves the hardening and mineralization of cartilage into bone. Depending on the breed of horse, bones will continue to grow until the horse is two years old. Larger Warmblood breeds will continue to grow later in age than a Quarter horse. 
Some problems are self-limiting and can correct themselves as the horse gets older. However, if the problems are severe, they may ultimately affect the soundness and future potential for the horse.

Nutrition can play a role in the incidence of DOD, especially when the diet is not properly balanced. Common problems are:

- excess energy in the diet

- inadequate or imbalanced mineral supplementation

High protein diets are commonly thought to contribute to DOD, but research has shown that diets high in energy, not protein, are associated with increased incidence of DODs. A good source of quality protein is essential for sound growth.

\section{Feeding Programs for the Young Horse}

\section{Nursing Foal}

For the first two to three months of their lives, foals will meet most if not all of their nutritional requirements from their mother's milk.

However, after three months of age, the foal will need increasingly more and more nutrients from feed as the mother's milk production will drop off and the foal gets bigger. Furthermore, at this age, pasture production and quality is dropping as the fall approaches. In order to satisfy the nutritional requirements of the foal, creep feeding is an important practice.

Creep feeding should be started at least one month prior to weaning and, if possible, by two to three months of age.

The creep feed will be only accessible to the foal. It serves two purposes:

- it compliments the nutrients that the mare's milk and pasture provide to the young foal, and as the foal gets older, satisfies its increased nutritional needs

- allows the foal to become accustomed to eating grain and helps reduce the stress of weaning

To ensure only the foal has access to creep feed, either tie the mare up in the stall while the foal is being fed, or build special foal-friendly creep feeders that only allow the foal access. For building plans, see Alberta Agriculture and Rural Development's factsheet Horse Handling Facilities (Agdex 460/722-1).

Creep feed should be fed to compliment the mare's milk, and not to produce a fat foal. Feed the foal to keep optimal body condition.

Nutrient concentrations needed in a creep feed are provided in the following table (Table 23). Good quality protein, energy and appropriate balanced minerals, especially calcium, phosphorus, zinc and copper, are essential for good sound growth. 
Creep feeds are commercially available and a mix can be made on farm with:

- 70 per cent oats

- 30 protein supplement (30 per cent $\mathrm{CP}$ )

- a vitamin/mineral premix

It should be fed at a rate from 0.5 to 1 per cent of the foals' body weight per day, or 0.5 to 1 pound for every 100 pounds of body weight.

\begin{tabular}{l|l}
\hline Crude protein & Regsmimendigd level \\
\hline Calcium & 16 to $18 \%$ \\
Phosphorus & 0.8 to $1.0 \%$ \\
Copper & 0.6 to $0.8 \%$ \\
Zinc & 10 to $30 \mathrm{mg} / \mathrm{kg}$ \\
& 40 to $120 \mathrm{mg} / \mathrm{kg}$ \\
\hline
\end{tabular}

Table 23. Recommended composition of creep feed for foals

Use the higher levels of protein and calcium with grass forage.

Use the lower levels of protein and calcium with alfalfa forage.

From Alberta Agriculture and Rural Development's factsheet Feeding Young Horses for Sound Growth (Agdex 460/50-2).

\section{Weanlings}

The weaning period can be a very stressful time for the foal. It can reduce immunity and growth, and contribute to DOD. Some ways that weaning stress can be reduced:

- accustom the foal to creep feed/grain before weaning

- allow visual contact after weaning (i.e. across a fence) for a week after weaning, using pasture weaning instead of weaning in stalls

- relocating mares rather than relocating the foals

- using a foal-sitter, such as an old gelding or dry mare that the foal is familiar with to give the foal company during the weaning process

Weanlings need a nutrient-dense diet that is appropriately balanced for energy, protein, vitamins and minerals. At three to six months of age, the foal needs about 15 per cent crude protein in their total diet.

Depending on whether they are on grass hay or an alfalfa-based hay, the protein concentration in the concentrate part of the diet can differ. Grass hay will only contain around 8-10 per cent crude protein; therefore, on average, the foal needs 15 per cent protein in its diet, the concentrate portion of their diet will need to be a lot higher.

A commercial foal feed can be used that averages around 16-20 per cent crude protein. At this age, the forage portion of the foal's diet should be around 40-60 per cent, and the concentrate portion around 40-60 per cent. If grass hay is used, then feed more concentrate (at 50-60 per cent). If an alfalfa-based hay is fed, then the concentrate portion can be lower. 
Horses under one year of age should not be fed a diet consisting entirely of plain oats and hay. There is not enough protein or minerals in this diet for the young growing horse. Feeding a young horse this diet could lead to bone problems or DOD.

Instead, the hay, whether alfalfa or grass, should be complemented with a commercial feed designed for foals containing appropriate amounts of protein and minerals. Alternatively, plain oats can be mixed with a protein supplement and a vitamin/mineral premix.

Do not overfeed the foal as this can also lead to bone problems. Feed to ensure a healthy body condition score of 5 .

To prevent the occurrence of DOD, weanlings should be:

- allowed to grow at a steady, moderate rate of growth

- fed a well-balanced diet that provides all of the energy, protein vitamins and minerals that they need

Refer to Table 24 for examples of rations for weanlings.

Foals should be allowed exercise as this contributes to bone strength. Prolonged stall rest should only be considered under veterinarian's recommendations.

If a horse has a genetic predisposition for DOD, it should be fed a balanced diet for energy protein and minerals. The horse should be carefully monitored for growth and the ration adjusted if necessary.

Some companies produce special feeds for horses with DOD tendencies. Sources of energy in these feeds are usually from a "safer," more fibrous source, than are the starches that are usually provided in grains.

\begin{tabular}{l|ll} 
& & \\
Mixed alfalfa/grass hay & $4.5 \mathrm{~kg}(10 \mathrm{lbs})$ & - \\
Grass hay & - & $3.6 \mathrm{~kg}(8 \mathrm{lbs})$ \\
Oats & 1.8 to $2.2 \mathrm{~kg}(4$ to $5 \mathrm{lbs})$ & $2.2 \mathrm{~kg}(5 \mathrm{lbs})$ \\
$30 \%$ protein supplement & $0.6 \mathrm{~kg}(1.25 \mathrm{lbs})$ & $1 \mathrm{~kg}(2 \mathrm{lbs})$ \\
TM salt & Free choice & Free choice
\end{tabular}

Table 24. Example rations for weanlings From Alberta Agriculture and Rural Development's factsheet Feeding Young Horses for Sound Growth (Agdex 460/50-2).

\section{Yearlings}

By the time a horse is a year old:

- its rate of growth slows down

- its digestive tract is more mature and larger and it can accommodate more bulky, fibrous feeds

In other words, it can handle a lot more hay in its diet, and less energy and protein-dense concentrates need to be fed in order to meet its requirements. 
Yearlings are still growing and will need more protein than the mature horse. As such, a high quality hay or pasture should be available. If the hay contains alfalfa, it may supply all of the horses energy and protein needs.

Mineral supplementation to ensure healthy bones is a must. Minerals can be provided as a vitamin/mineral premix and can be:

- fed free choice

- mixed with salt (two parts mineral to one part loose salt)

- mixed with grain

If the horse is on grass hay, then a concentrate mix should be fed offering higher protein than oats alone. The oats can be mixed with $1 / 4$ soybean meal or 30 per cent protein supplement, and a vitamin/mineral mix. Sample diets are outlined below in Table 25.

\begin{tabular}{|c|c|c|c|}
\hline $5=0$ & Dret $\Lambda$ & Diet B & Diet is \\
\hline Mixed alfalfa/grass hay & $10 \mathrm{~kg}(20 \mathrm{lbs})$ & $5.5 \mathrm{~kg}(12 \mathrm{lbs})$ & - \\
\hline Grass hay & - & - & $6.8 \mathrm{~kg}$ (15 lbs) \\
\hline Oats & - & $2.2 \mathrm{~kg}(5 \mathrm{lbs})$ & $2.2 \mathrm{~kg}(5 \mathrm{lbs})$ \\
\hline $30 \%$ protein supplement & - & - & $0.5 \mathrm{~kg}(1 \mathrm{lb})$ \\
\hline 18:18 mineral & $28 \mathrm{~g}(1 \mathrm{oz})$ & $28 \mathrm{~g}(1 \mathrm{oz})$ & - \\
\hline TM salt & Free choice & Free choice & Free choice \\
\hline
\end{tabular}

Table 25. Sample rations for yearlings and two-year olds.

From Alberta Agriculture and Rural Development's factsheet Feeding Young Horses for Sound Growth (Agdex 460/50-2).

\section{Two-year Olds}

At this age, the horse is approaching its full height and weight, and his nutritional needs are also approaching those of mature horses. It is still important at this young age to provide the horse with high quality forage, and to ensure that his protein and mineral needs are met.

An alfalfa/grass mix hay will meet the horse's energy and protein needs. However mineral supplementation is still needed. If grass hay is fed, some grain may still be required to meet their energy and protein requirements, as well as appropriate mineral supplementation. Key minerals are still those needed for healthy strong bones, namely calcium, phosphorus, copper and zinc.

If the horse is in training, it will have energy needs that surpass what is provided in hay. A feed such as grains and concentrates that contains a higher energy per pound will need to be fed. Depending on the amount of training, an additional 4 to 10 pounds of concentrate will be needed. Appropriate levels of minerals are also important, and it is sometimes easier to feed a 12-14 per cent commercial grain mix that already contains added vitamins and minerals. 


\section{FEEDING MANAGEMENT OF THE PERFORMANCE OR WORKING HORSE}

Horses are noted for their exceptional athleticism and many people own their horses for sport and recreation. Whether it is for the occasional trail ride, training for rodeo events or show jumping, or racehorses, feeding management will differ to meet the individual horse's requirement and maximize its potential for the desired activity.

The exercising horse will have increased nutritional needs over a non-exercising horse, specifically in energy, minerals and vitamins.

The biggest demand is for increased energy. The muscles need a source of fuel to contract and do work, and this fuel can be in the form of either carbohydrates (glucose and glycogen stores) or fat (fat stores). Although the protein levels that the horse requires increase due to muscle use and turnover, the required increase in energy is greater than protein. Therefore, if the horse's energy needs are met, his protein needs will typically be met.

Supplemental minerals and vitamins may be needed depending on the:

- amount of exercise that the horse does

- amount of grain in the diet

- type of stabling of the performance horse

Adequate amounts of calcium and phosphorus are important for maintenance of strong healthy bones while the trace minerals copper and zinc are important for proper bone growth in young horses. A supplement containing calcium and phosphorus is desired for performance horses.

Alberta forages are low in copper and zinc, as well as manganese and selenium, thus a trace mineral supplement would also be beneficial for all horses.

For horses stabled indoors and on high grain diets, the vitamins $\mathrm{A}$ and $\mathrm{E}$ and the $\mathrm{B}$ complex may be beneficial.

A simple, balanced mineral/vitamin premix and a salt block is an efficient way to ensure that the horse meets his nutrient requirements for all vitamins and minerals. There is no added benefit to over supplementation of minerals and vitamins. In some cases the effects can be toxic, and for the $\mathrm{B}$ vitamins, any extra is promptly excreted in urine.

Minerals that are excreted in sweat such as salt, potassium and magnesium (termed electrolytes) are also important for those horses that exercise. In situations where the horse sweats excessively, and in hot, humid conditions, loose salt may need to be top-dressed to the ration to ensure adequate intake, and electrolytes containing potassium, sodium and chloride may be given.

Good quality forage should always form the basis of the diet of the exercising horse. Forages contain the fibre, energy and protein that horses need, and they are high in calcium and vitamins.

- a horse that exercises at a light intensity can have all of his energy needs met by feeding good quality forage, such as an alfalfa/grass mixed hay

- a horse exercising at high intensity should receive a minimum of one per cent of its body weight in forage 
Studies have shown that at one per cent forage in the diet there are no disadvantages to racing performance. However, the increased energy demands of exercising horses dictates that the energy density of the diet be increased, such as with the addition of energy dense concentrates. These concentrates can be in the form of grains or fats.

Commonly fed grains are

- oats

- corn

- barley

Barley and corn do contain higher energy than oats and are heavier and are typically referred to as "hot" feeds. A gallon of corn will provide twice as much energy as a gallon of oats; as such, feed should be fed by weight and not by volume.

If the horse is receiving a large quantity of grain, the grain meals should be fed more frequently throughout the day and never with more than five pounds of grain per feeding.

Commercial grain mixes are also convenient and incorporate both minerals and vitamins in the ration to ensure adequate intakes. There are feed mixes specially formulated for high performance horses. They typically contain:

- around 12-13 per cent protein

- high energy density

- added fat, vitamins and minerals

Too much grain can cause digestive problems in the performance horse such as colic, laminitis and gastric ulcers. Replacement of some of the grain with fat can reduce the incidence of these problems.

Fats are an excellent energy source for the active horse. Fat is very easily digested, and does not contribute to the glucose spike seen in horses being fed grains with high starch content (Figure 8). This allows fat to be a good energy source without being a "hot" feed.

Fats can be fed in the form of oil such as canola or corn oil. One cup of oil can replace $1 \frac{1}{2}$ pounds of oats (see Table 27), and horses should be limited to two cups of oil a day. Some commercial horse feeds for the performance horse have oil included in them.

\section{Tips for feeding oil}

Oil can replace a portion of the grain in the diet.

- oil should be introduced gradually into the diet over a period of 7 to 10 days

- the maximum amount of oil included in the diet should be two cups, or five per cent of the diet

- oil (unprocessed) purchased at feed mills in barrels contains more vitamins and is a better choice than oil purchased at the grocery store

- canola oil is a good choice as it contains high amounts of essential fatty acids 


\section{Feeding the Horse in Light Work}

Horses that fall in this category are ridden three to five times a week for pleasure.

The horse's energy requirements will increase by 25 per cent over maintenance levels and can usually be met just by increasing the quantity of good quality hay that is being fed without adding grain to the diet.

If the horse is not able to maintain its body condition or if the hay is not of high quality, the horse will benefit with a small amount of additional grain. Table 26 has feeding suggestions for this type of horse.

\section{Feeding the Horse in Moderate Work}

Moderate work typically includes horses in training and competition for:

- barrel racing

- ranch work

- cutting

- dressage

- jumping

These horses should be monitored closely for maintenance of their body condition and the feeding regime should be adjusted accordingly. Some horses can maintain their body condition on good quality hay alone, while others may need some grain added to the diet to increase the energy density. Suggestions for rations are listed in Table 26.

\section{Feeding the Horse in Intense Work}

This category is for horses that are competing in racing, polo or endurance riding.

Energy demands for these horses are double the idle horse and the energy density of the diet should be increased. Grain supplementation is necessary and added fat is beneficial. Feeding suggestions are listed in Table 26.

Depending on whether the horse is involved in racing or endurance work, different types of feeds may affect its performance.

An endurance horse will use fat as energy more so than a racehorse, and requires a large amount of energy and water to perform well while exercising. This horse should be fed throughout competition. Hay is an excellent feedstuff for this as it provides a constant supply of energy and retains water in the horse keeping it hydrated.

For racehorses, removing hay four hours before competition will reduce the load that the horse has to carry for its short-distance exertion.

For optimal performance, a grain meal should be fed four hours before exercise. The high starch content of grains results in a spike in blood glucose causing a rise in insulin levels (Figure 9). Insulin prevents the muscles from making the best use of nutrients for contraction and the horse may fatigue quicker. Allowing four hours between a grain meal and exercise allows the insulin levels to come down to baseline, and maximizes performance. Proteins, fats and cellulose from hay do not contribute to this glucose "spike." 


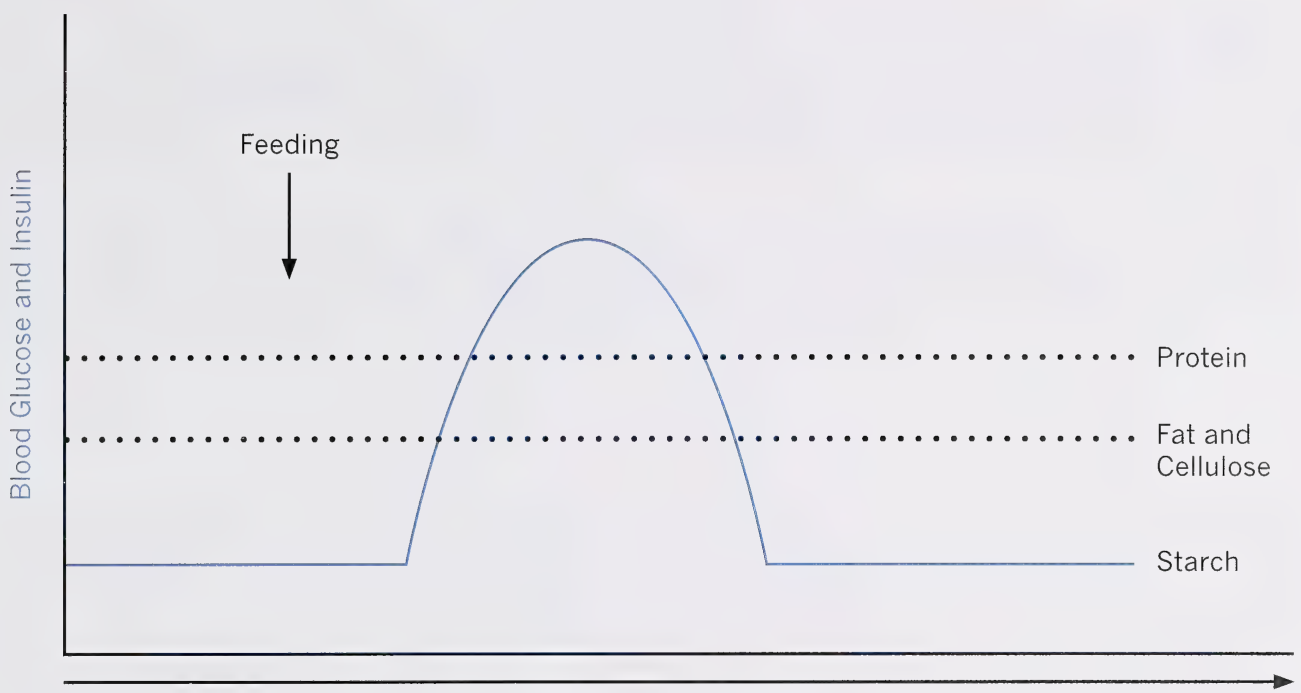

Time After Feeding

Figure 9. Blood glucose and insulin levels after feeding a meal.

\begin{tabular}{|c|c|c|c|c|c|c|c|}
\hline Araitroul & 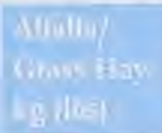 & 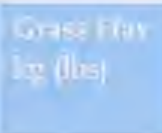 & $\begin{array}{l}\text { lkats-lyge } \\
\text { (ths) }\end{array}$ & 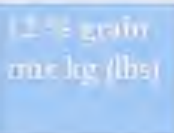 & 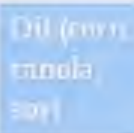 & 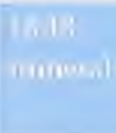 & in \\
\hline \multicolumn{8}{|c|}{ Lighi Now } \\
\hline Ration A & $9(20)$ & - & - & - & & $28 \mathrm{~g}$ & Yes \\
\hline Ration B & $6.5(14)$ & - & $1.75(3-4)$ & - & & $28 \mathrm{~g}$ & Yes \\
\hline Ration C & - & $7.25(16)$ & - & $1.75(3-4)$ & & $28 \mathrm{~g}$ & Yes \\
\hline \multicolumn{8}{|c|}{ Modertis that } \\
\hline Ration A & $11(25)$ & - & - & - & & $28 \mathrm{~g}$ & Yes \\
\hline Ration B & $7-8(15-17)$ & - & $2-3(5-7)$ & - & & $28 \mathrm{~g}$ & Yes \\
\hline Ration C & - & $8.2(18)$ & - & $2-3(5-7)$ & & - & Yes \\
\hline \multicolumn{8}{|c|}{ 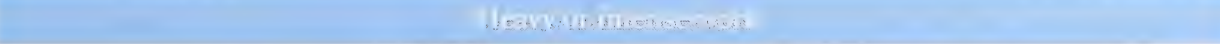 } \\
\hline Ration A & $7-8(15-17)$ & - & $5(10-11)$ & - & & $28 \mathrm{~g}$ & Yes \\
\hline Ration B & - & $8-9(17-19)$ & & $5(10-11)$ & & - & Yes \\
\hline Ration C & - & $8-9(17-19)$ & - & $4.5(8.5-9.5)$ & 1 cup & - & Yes \\
\hline
\end{tabular}

Table 26. Sample rations for horses in light, medium or intense work.

From Alberta Agriculture and Rural Development's factsheet Feeding and Managing Considerations for Horses (Agdex 460/50-4). 


\section{FEEDING IMANAGEMENT OVER WINTER}

Horses are hardy animals and can handle an Alberta winter outdoors. However, there are a few management practices that can help ensure horses are healthy and in good condition when spring comes.

It is important to regularly assess the horse's overall body condition. Keep note of the horse's body condition score (see Alberta Agriculture and Rural Development's factsheet Body Condition Scoring Your Horse (Agdex 460/20-1)), and look at their coat and hoof condition.

- if the horse has a blanket on, ensure that you are looking underneath it

- if the horse has a heavy winter coat, use your hands to check the fat cover over the ribs to assess body condition

A good way to keep tabs on weight gain or loss is to take a piece of string, wrap it around the horse's girth and make a knot where the string meets itself. This string can then be used as a guide to determine whether the horse gains or loses weight.

A horse needs some form of protection from the elements, rain, snow, wind and the cold. A shelter is necessary, although it may take the form of a thick forest, a three-walled shed or even a barn. Building plans for a horse shelter can be found in Alberta Agriculture and Rural Development's handbook Horse Handling Facilities (Agdex 460/722-1).

A blanket for the horse is not necessary. It is best for a horse that is not ridden much through the winter and mainly kept outdoors to grow their full winter coat and use it as their natural protection and insulation.

The nutritional needs for the horse over the winter will increase by about 20 per cent in some cases, as the horse needs to eat more to keep warm against the colder temperatures. Increase the amount of hay fed to the horse, as fibrous feeds create more heat for the horse while they are being digested.

Hay quality is critical in winter. Poor quality hay will become evident as the horse's condition deteriorates over the winter. Poor quality hay will typically be too fibrous, and not provide enough energy and protein for the horse. The horse will lose weight and his coat will look rough. Yearlings and broodmares will typically be most affected and a good sign that the yearling is not getting enough protein is a rough thick hair coat that is not shed in the summer.

When choosing hay for the winter, have an analysis done to ensure that it meets requirements for protein and energy. Hay with less than eight per cent CP on a dry matter basis will need to be supplemented with oats, alfalfa cubes or pellets or a commercial grain ration.

If the horses are kept on pasture for the winter, they are able to paw and get grass from under the snow. However, snow conditions will dictate how effective their pawing will be. Similarly, the amount of feed and its nutritional quality are variable and dependent on the quality, quantity and maturity of the pasture before growing ceased in the fall. Provide supplemental hay as necessary.

Mineral and vitamin supplementation is recommended over the winter, and ensure that the horse has access at all times to trace-mineralized salt. Loose-form salt is more readily consumed in the winter compared to the block form, so if the horse has problems taking in enough salt, loose salt is ideal. A vitamin and mineral premix can be mixed in with the loose salt to satisfy the horse's requirements. 
Optimal water consumption is critical during the winter months, because it reduces the chances of impaction colic and also stimulates feed consumption. Similarly, salt consumption encourages water consumption, which then dictates how much feed the horse will voluntarily eat. As such, ensuring that salt and water are available at all times is key to keeping a horse healthy over the winter.

Although horses are able to eat snow to offset water intake, snow cannot be depended upon as the sole source of water. A horse would have to eat over $60 \mathrm{lbs}$ of snow a day to meet his water requirements. This also requires the horse to expend energy heating up the snow to body temperature.

Potable water should be provided either through automatic watering systems or insulated water troughs. Floating water heaters are available, or alternatively, ice on the waters surface should be broken several times daily to allow the horse to drink.

Horses have a hierarchy amongst themselves. If food or water are scarce, it will be the dominant horses that consume the majority, leaving the young subordinates last pick. If some horses are not doing well or not in good condition, it is best to segregate them and to feed and water them individually.

\section{FEEDING MANAGEMENT OF THE AGING HORSE}

With proper care and attention, some horses will remain useful into their late 20s. Careful feeding of these horses will minimize their health problems.

One of the most important points to consider with older horses is that each horse should be managed as an individual. Each horse will most likely have different health problems that may involve:

- bad teeth

- different histories

- metabolic problems

- different feeding regimes

Similarly, older horses have more difficulty dealing with adverse environmental conditions such as cold or wind.

The type of feeding program recommended for one horse may not work for another. A good assessment of the health status of the horse is essential to provide a basis for a good feeding program for the horse. Furthermore, assessments made on an ongoing basis will ensure the feeding program is adequate for the horse and, at the same time, catch potential problems. Proper veterinary care, including deworming, vaccinations and teeth examinations is important. 
The older horse may experience problems with weight loss, or just poor condition. There are many factors that can play a role, such as:

- parasite load

- disease or health problems

- bad teeth

- reduced ability to digest their feed and to absorb the nutrients obtained from the digestion of feed

If there are problems, a veterinarian should monitor the horse's health and assess whether medical problems exist.

Underweight horses without serious health complications would benefit from:

- a form of highly digestible energy

- feeds that are processed to increase digestibility

- feeds containing about 12 per cent protein

- proper supplementation of minerals, especially calcium and phosphorus

More energy will be required in adverse environmental conditions to maintain the horse's condition. Horses with digestive problems and poor appetite may benefit from supplementation with B vitamins. Brewer's yeast is a good source of B vitamins.

Bad, missing or worn teeth are a common cause of weight loss in the aged horse. This horse is not able to properly chew its feed to obtain the nutrients from the feed as a horse with good teeth can. These horses are more prone to choke. Horses with worn teeth would benefit from processed complete feeds, such as extruded or pelleted feeds.

There are many commercial feeds on the market that are specifically designed for the aged horse. However, an aged horse that is not in bad condition with poor teeth will benefit from rolled oats or barley, and the addition of vegetable oil. Oil is highly digestible, and will provide a good source of energy for the older horse. Oil can be included at a rate of one to two cups per day in the diet.

Supplementation with adequate vitamins and minerals should also be considered for the older horse. A source of fibre, such as forage or roughage is still essential for older horses, and should not be lower than one per cent of body weight to ensure a healthy digestive tract.

Some older horses may have trouble properly digesting long-stem hay, but if they want to eat it, it should be provided to allow them to occupy their time chewing. An older horse can do very well on good quality hay, such as an mixed alfalfa/grass hay because this hay is rich in energy and protein, and is more digestible. If hay is a problem, hay cubes can replace some of the longstemmed hay.

Beet pulp can be a good alternative roughage and fibre source. 
Becoming overweight is a potential problem for older horses. There may be some underlying metabolic problems that have caused the horse to become overweight, but being overweight is dangerous for the horse and can exaggerate metabolic problems and lead to laminitis. Underlying metabolic problems can be due to:

- thyroid tumours

- cushing's disease

- metabolic syndrome

- insulin resistance and others

Lack of exercise and overfeeding can definitely contribute to the development of these problems or aggravate the condition.

Overweight horses would benefit from reduced starch intake. As such:

- reduce grains and concentrates in their diet

- limit their access to pasture

A diet based on good quality grass hay with mineral and vitamin supplementation, and with a restriction on the quantity of hay, will ensure that the horse can maintain its body condition or lose weight safely. Added light exercise for those horses that are allowed to exercise will help improve the horse's health and condition.

Kidney and liver problems are common in older horses. Decreased kidney function can lead to:

- the formation of kidney stones

- weight loss

- loss of appetite

For horses with kidney problems, the calcium and phosphorus levels of the diet should be kept low $(0.45$ per cent of the total diet), while still meeting their requirements.

Horses with liver problems will have a reduced capacity to metabolize fats and proteins, and high protein diets also make the kidneys work harder.

Feedstuffs containing high calcium such as alfalfa and beet pulp should be avoided in horses with kidney problems, and protein levels of the diet should be kept at or below 12 per cent in horses with liver and/or kidney problems. A diet based on good quality grass hay is ideal for these horses, with supplemental energy provided in the form of oats, corn and oil. Specially formulated low-protein "senior" feeds may be a good choice as an addition to hay.

Proper veterinary attention, assessment of body condition and a well-balanced diet formulated for his specific needs can go a long way to ensure that the older horse can live a healthy, happy life. 


\section{Feeding Tips: Aging Horse}

Most importantly, the diet of the senior horse should be highly digestible, palatable and suited to its particular needs.

A legume/grass mix of hay or pasture is ideal, and hay can also be provided in the form of alfalfa cubes. Alfalfa pellets can also be used as a supplement to grass hay.

The grain should be processed by rolling, pelleting or extruding before feeding. This is especially true for horses with bad or worn teeth.

The diet should contain:

- a highly digestible form of energy

- 12-14 per cent crude protein

- adequate calcium and phosphorus to meet the horse's needs

- Vegetable oil is an excellent highly digestible form of energy for the aged horse. Feed one to two cups per day.

- Ensure that the horse has adequate mineral and vitamin supplementation.

- Access to potable water at all times will ensure high intake of feed and limit digestive problems.

- Horses with teeth problems and poor appetites may benefit from complete feeds that provide both concentrates and fibre. These feeds can be watered down to make a soup that is easily digested while encouraging water intake.

- Frequent veterinary attention is important, especially to ensure that the horse is dewormed and that his teeth are checked regularly (twice a year).

- Adverse weather conditions, such as winter, can greatly increase the aging horse's requirements for energy. 


\section{APPENDIX 1. Typical Nutrient Values for Horse Feeds}

NOTE: Values are on an as-fed basis*

\begin{tabular}{|c|c|c|c|c|c|c|}
\hline 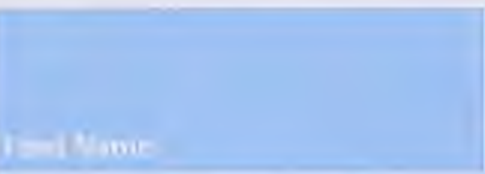 & $\begin{array}{c}\text { vosy } \\
\text { salker } \\
\text { curilent } \\
\text { (89) }\end{array}$ & $\begin{array}{l}\text { tac } \\
\text { Migal } \\
\text { lga }\end{array}$ & $\begin{array}{l}\text { Grube } \\
\text { filore } \\
\frac{\pi}{31}\end{array}$ & $\begin{array}{l}\text { Gonde } \\
\text { fहt } \\
\frac{4}{4}\end{array}$ & $\begin{array}{l}\text { resude } \\
\text { Protcin } \\
\text { is }\end{array}$ & $\begin{array}{c}\text { Lyame } \\
\text { is }\end{array}$ \\
\hline \multicolumn{7}{|l|}{ Cone mitrito } \\
\hline $20 \%$ Multipurpose Horse Supplement & 90 & 2.8 & 8.0 & 2.0 & 20.0 & 0.8 \\
\hline Barley Grain & 88 & 3.3 & 4.9 & 1.8 & 11.1 & 0.5 \\
\hline Beet Molasses & 78 & 2.7 & 0.0 & 0.2 & 6.6 & 0.4 \\
\hline Beet Pulp & 82 & 2.1 & 18.0 & 0.5 & 8.2 & 0.5 \\
\hline Brewer's Grain, Dehydrated & 92 & 2.5 & 13.7 & 5.9 & 23.4 & 0.9 \\
\hline Brewer's Grain, Wet & 26 & 0.7 & 3.9 & 1.7 & 7.6 & 0.3 \\
\hline Canola Meal & 92 & 3.1 & 11.0 & 2.8 & 39.2 & 2.1 \\
\hline Canola Oil & 100 & 9.0 & 0.0 & 99.7 & 0.0 & 0.0 \\
\hline Canola Seed & 90 & 5.0 & 8.0 & 36.5 & 18.5 & 1.0 \\
\hline Corn Gluten Feed & 90 & 3.5 & 8.0 & 3.2 & 21.4 & 0.5 \\
\hline Corn Grain & 85 & 3.3 & 2.2 & 3.6 & 8.8 & 0.3 \\
\hline Distiller's Grain & 79 & 2.9 & 13.5 & 9.1 & 24.7 & 0.7 \\
\hline Flaxseed Meal & 90 & 2.7 & 9.1 & 1.4 & 34.6 & 1.2 \\
\hline Flaxseed, Milled & 92 & 3.4 & 6.0 & 37.0 & 20.0 & 0.9 \\
\hline Flaxseed, Whole & 93 & 3.4 & 6.2 & 36.0 & 21.1 & 0.9 \\
\hline Oats, Groats & 90 & 3.1 & 2.3 & 6.1 & 15.5 & 0.6 \\
\hline Oats, Hull-less & 89 & 3.9 & 2.7 & 9.0 & 14.0 & 0.7 \\
\hline Oats, Whole & 90 & 3.1 & 10.7 & 4.6 & 10.7 & 0.3 \\
\hline Peas & 89 & 3.1 & 5.6 & 0.9 & 23.4 & 1.6 \\
\hline Rice Bran & 91 & 2.6 & 11.7 & 13.6 & 13.0 & 0.5 \\
\hline Rye Grain & 89 & 3.5 & 2.2 & 1.5 & 10.9 & 0.4 \\
\hline Soybean Hulls & 90 & 1.7 & 30.0 & 1.9 & 11.0 & 0.5 \\
\hline Soybean Meal & 89 & 3.1 & 6.2 & 1.4 & 44.5 & 3.1 \\
\hline Soybeans, Full Fat & 90 & 2.9 & 12.0 & 18.6 & 39.7 & 2.5 \\
\hline Sunflower Seeds, Meal & 90 & 2.6 & 26.0 & 1.3 & 45.2 & 1.7 \\
\hline Sunflower Seeds, Whole No Hulls & 92 & 4.9 & 14.0 & 38.5 & 17.7 & 0.6 \\
\hline Tallow & 100 & 7.9 & 0.0 & 98.4 & 0.0 & 0.0 \\
\hline Triticale Grain & 90 & 3.4 & 3.6 & 3.6 & 14.1 & 0.4 \\
\hline Wheat Bran & 89 & 2.9 & 10.0 & 3.8 & 15.5 & 0.6 \\
\hline Wheat Grain & 88 & 3.4 & 2.5 & 1.6 & 14.0 & 0.4 \\
\hline
\end{tabular}




\begin{tabular}{|c|c|c|c|c|c|c|c|c|c|c|}
\hline Cha ne & $8 \%$ & $\operatorname{lng} \times$ & is a & $\sqrt{x} x=$ & $51=$ & $\begin{array}{c}\mathrm{Cn} \\
\mathrm{gpm}\end{array}$ & ppm & $\begin{array}{l}\mathrm{Mm} \\
\text { Ppan }\end{array}$ & prom & $\begin{array}{l}\text { Vinaminn } 9 \\
\text { IIylige }\end{array}$ \\
\hline 2.6 & 1.5 & 0.3 & 1.0 & 0.6 & 0.3 & 80 & 220 & 160 & 0.6 & 40000 \\
\hline 0.1 & 0.3 & 0.1 & 0.5 & 0.0 & 0.2 & 5 & 38 & 17 & 0.1 & 817 \\
\hline 0.1 & 0.0 & 0.2 & 4.0 & 1.2 & 0.5 & 17 & 14 & 4 & 0.0 & na \\
\hline 0.4 & 0.2 & 0.2 & 1.4 & 0.2 & 0.2 & 4 & 19 & 44 & 0.1 & 88 \\
\hline 0.3 & 0.5 & 0.2 & 0.1 & 0.2 & 0.3 & 21 & 28 & 37 & 0.7 & na \\
\hline 0.1 & 0.2 & 0.1 & 0.1 & 0.0 & 0.1 & 2 & 31 & 15 & 0.1 & na \\
\hline 0.8 & 1.3 & 0.6 & 1.3 & 0.0 & 1.2 & 9 & 97 & 58 & 0.6 & na \\
\hline 0.0 & 0.0 & 0.0 & 0.0 & 0.0 & 0.0 & 0 & 0 & 0 & 0.0 & na \\
\hline 0.4 & 0.6 & 0.2 & 0.8 & 0.1 & 0.4 & 11 & 79 & 43 & 0.0 & na \\
\hline 0.1 & 1.0 & 0.4 & 1.4 & 0.3 & 0.5 & 5 & 73 & 22 & 0.3 & na \\
\hline 0.1 & 0.3 & 0.1 & 0.4 & 0.0 & 0.1 & 3 & 20 & 8 & 0.1 & 2000 \\
\hline 0.1 & 0.6 & 0.2 & 0.9 & 1.9 & 0.9 & 8 & 60 & 9 & 0.6 & 1200 \\
\hline 0.4 & 0.8 & 0.6 & 1.4 & 0.1 & 0.4 & 26 & 60 & 38 & 0.8 & na \\
\hline 0.2 & 0.5 & 0.4 & 0.7 & 0.0 & 0.2 & 19 & 69 & 61 & 0.0 & na \\
\hline 0.2 & 0.5 & 0.4 & 0.7 & 0.0 & 0.2 & 0 & 69 & 61 & 0.0 & na \\
\hline 0.1 & 0.4 & 0.1 & 0.6 & 0.1 & 0.1 & 3 & 35 & 36 & 0.5 & 44 \\
\hline 0.1 & 0.3 & 0.1 & 0.4 & 0.0 & 0.1 & 3 & 31 & 31 & 0.2 & 44 \\
\hline 0.1 & 0.3 & 0.1 & 0.5 & 0.1 & 0.2 & 5 & 31 & 41 & 0.1 & 49 \\
\hline 0.1 & 0.4 & 0.1 & 1.0 & 0.2 & 0.0 & 0 & 23 & 3 & 0.0 & 285 \\
\hline 0.1 & 1.5 & 0.9 & 1.7 & 0.0 & 0.2 & 11 & 30 & 360 & 0.4 & na \\
\hline 0.1 & 0.2 & 0.1 & 0.4 & 0.0 & 0.2 & 5 & 34 & 28 & 0.0 & 35 \\
\hline 0.5 & 0.2 & 0.2 & 1.2 & 0.0 & 0.1 & 16 & 98 & 110 & 0.5 & na \\
\hline 0.4 & 0.6 & 0.3 & 2.0 & 0.0 & 0.4 & 20 & 50 & 31 & 0.5 & na \\
\hline 0.2 & 0.5 & 0.2 & 1.7 & 0.0 & 0.3 & 16 & 47 & 30 & 0.2 & 1600 \\
\hline 0.4 & 0.9 & 0.7 & 1.2 & 0.0 & 0.0 & 4 & 97 & 19 & 0.1 & na \\
\hline 0.7 & 0.5 & 0.3 & 1.0 & 0.0 & 0.2 & 18 & 49 & 32 & 0.0 & na \\
\hline 0.0 & 0.0 & 0.0 & 0.0 & 0.0 & 0.0 & 0 & 0 & 0 & 0.0 & na \\
\hline 0.1 & 0.3 & 0.1 & 0.4 & 0.0 & 0.0 & 5 & 32 & 32 & 0.2 & na \\
\hline 0.1 & 1.1 & 0.6 & 1.2 & 0.1 & 0.2 & 13 & 98 & 119 & 0.5 & 1000 \\
\hline 0.1 & 0.4 & 0.3 & 0.4 & 0.0 & 0.1 & 4 & 37 & 33 & 0.2 & 1000 \\
\hline
\end{tabular}




\begin{tabular}{|c|c|c|c|c|c|c|}
\hline Fant Natore & $\begin{array}{l}\text { Dory } \\
\text { staver } \\
\text { contem } \\
\text { (u) }\end{array}$ & $\begin{array}{l}\text { DE } \\
\text { Mca्l/ } \\
\text { kू }\end{array}$ & $\begin{array}{l}\text { Crude } \\
\text { fibre } \\
\text { sy }\end{array}$ & 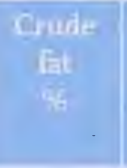 & $\begin{array}{l}\text { Crude } \\
\text { Protein } \\
\text { of }\end{array}$ & $\begin{array}{c}\text { 1.y-gine } \\
36\end{array}$ \\
\hline Wheat Middlings & 91 & 3.0 & 10.0 & 4.1 & 17.0 & 0.6 \\
\hline \multicolumn{7}{|l|}{ Ponrague } \\
\hline Alfalfa Hay & 89 & 2.2 & 25.0 & 2.5 & 15.9 & 0.7 \\
\hline Alfalfa Pellets & 91 & 2.5 & 26.7 & na & 16.0 & 0.7 \\
\hline Alfalfa-Grass Mixed Hay & 90 & 2.2 & 26.0 & 2.2 & 13.3 & 0.5 \\
\hline Alfalfa-cereal pellet & 87 & 2.0 & 25.0 & na & 14.0 & 0.3 \\
\hline Barley Straw & 91 & 1.5 & 37.8 & 1.7 & 4.0 & na \\
\hline Bromegrass Hay & 89 & 1.8 & 28.0 & 1.9 & 8.5 & 0.3 \\
\hline Clover-Grass Mixed Hay & 86 & 2.3 & 25.0 & 2.5 & 10.8 & 0.5 \\
\hline Creeping Red Fescue & 88 & 1.8 & 25.0 & 2.0 & 8.3 & 0.3 \\
\hline Native Grass Hay & 90 & 1.7 & 33.0 & 3.0 & 7.4 & 0.3 \\
\hline Oat Hay & 87 & 1.8 & 30.0 & 4.0 & 8.2 & 0.3 \\
\hline Oat Straw & 92 & 1.5 & 37.2 & 2.0 & 4.1 & 0.1 \\
\hline Orchardgrass Hay & 88 & 2.0 & 33.0 & 3.0 & 7.6 & 0.4 \\
\hline Timothy Hay & 88 & 1.7 & 28.0 & 2.0 & 7.3 & 0.2 \\
\hline Timothy Straw & 90 & 1.5 & 38.0 & 1.8 & 4.0 & 0.1 \\
\hline Wheat Straw & 91 & 1.5 & 38.0 & 1.8 & 3.2 & 0.1 \\
\hline \multicolumn{7}{|l|}{ 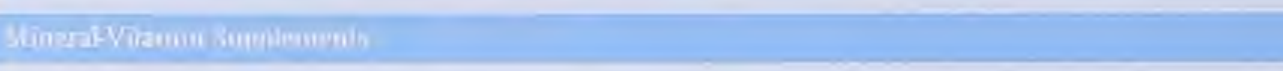 } \\
\hline 8:8 Mineral Block & 100 & 0.0 & 0.0 & 0.0 & 0.0 & 0.0 \\
\hline 1:2 Mineral & 100 & 0.0 & 0.0 & 0.0 & 0.0 & 0.0 \\
\hline 15 \% Mineral Block & 100 & 2.8 & 0.0 & 0.0 & 15.0 & 0.0 \\
\hline 18:18 Mineral & 100 & 0.0 & 0.0 & 0.0 & 0.0 & 0.0 \\
\hline 19:9 Mineral & 100 & 0.0 & 0.0 & 0.0 & 0.0 & 0.0 \\
\hline Dicalcium Phosphate & 100 & 0.0 & 0.0 & 0.0 & 0.0 & 0.0 \\
\hline Horse Mineral/Vitamin Premix & 100 & 0.0 & 0.0 & 0.0 & 0.0 & 0.0 \\
\hline Limestone & 100 & 0.0 & 0.0 & 0.0 & 0.0 & 0.0 \\
\hline Iodized Salt & 100 & 0.0 & 0.0 & 0.0 & 0.0 & 0.0 \\
\hline Iodized Salt + Cobalt (130 ppm) & 100 & 0.0 & 0.0 & 0.0 & 0.0 & 0.0 \\
\hline TM Salt + Selenium (120 ppm) & 100 & 0.0 & 0.0 & 0.0 & 0.0 & 0.0 \\
\hline TM Salt & 100 & 0.0 & 0.0 & 0.0 & 0.0 & 0.0 \\
\hline
\end{tabular}

*To convert from As.fed basis to $100 \%$ Dry Matter use the equation:

As.fed Value X $100 \div$ Dry Matter Content $\%=100 \%$ Dry Matter Basis Value 


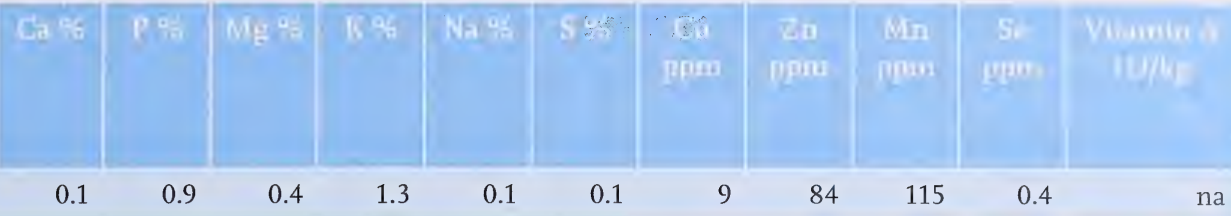

$\begin{array}{lllllllllll}1.6 & 0.2 & 0.3 & 1.6 & 0.0 & 0.2 & 6 & 22 & 36 & 0.2 & 40000\end{array}$

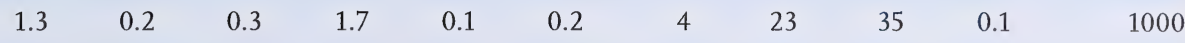

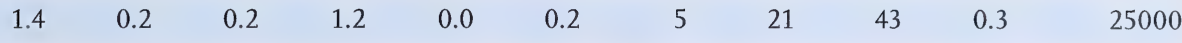

$\begin{array}{lllllllllll}1.2 & 0.2 & 0.2 & 1.4 & 0.0 & 0.1 & 4 & 19 & 37 & 0.1 & 5000\end{array}$

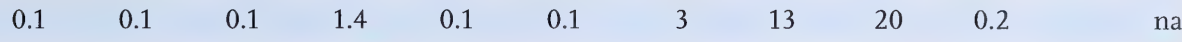

$\begin{array}{lllllllllll}0.5 & 0.1 & 0.1 & 1.5 & 0.0 & 0.1 & 4 & 17 & 64 & 0.1 & 10000\end{array}$

$\begin{array}{lllllllllll}0.8 & 0.2 & 0.2 & 1.6 & 0.0 & 0.1 & 5 & 22 & 30 & 0.1 & 5000\end{array}$

$\begin{array}{lllllllllll}0.5 & 0.2 & 0.2 & 1.4 & 0.0 & 0.1 & 5 & 17 & 114 & 0.1 & 10000\end{array}$

$\begin{array}{lllllllllll}0.4 & 0.1 & 0.1 & 0.9 & 0.1 & 0.2 & 4 & 18 & 50 & 0.1 & 10000\end{array}$

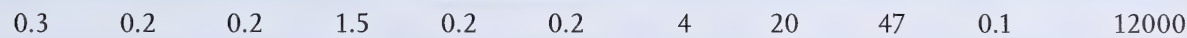

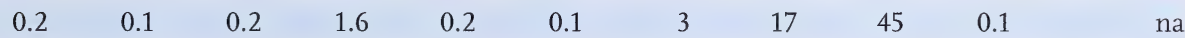

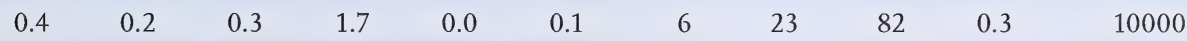

$\begin{array}{lllllllllll}0.4 & 0.1 & 0.1 & 1.1 & 0.0 & 0.1 & 4 & 18 & 42 & 0.1 & 18000\end{array}$

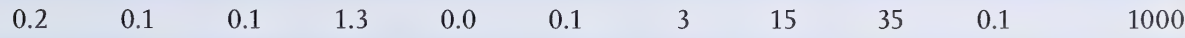

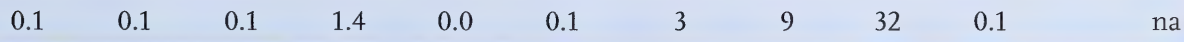

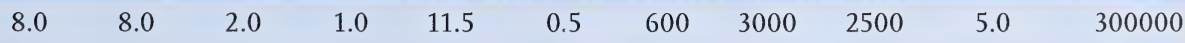

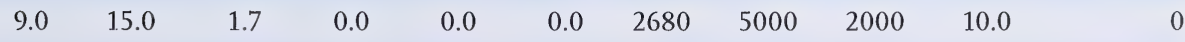

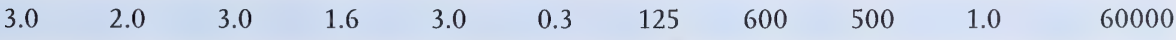

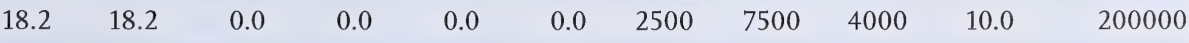

$\begin{array}{lllllllllll}19.2 & 9.1 & 0.0 & 0.0 & 0.0 & 0.0 & 500 & 3000 & 1500 & 10.0 & 200000\end{array}$

$\begin{array}{llllllllllr}16.0 & 22.0 & 0.0 & 0.0 & 0.0 & 0.0 & 0 & 0 & 0 & 0.0 & 0\end{array}$

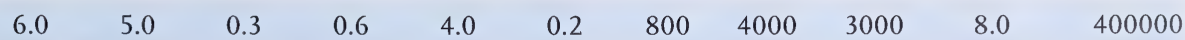

$\begin{array}{lllllllllll}38.0 & 0.0 & 0.0 & 0.0 & 0.0 & 0.0 & 0 & 0 & 0 & 0.0 & 0\end{array}$

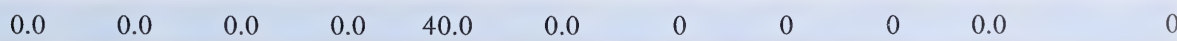

$\begin{array}{lllllllllll}0.0 & 0.0 & 0.0 & 0.0 & 40.0 & 0.0 & 0 & 0 & 0 & 0.0 & 0\end{array}$

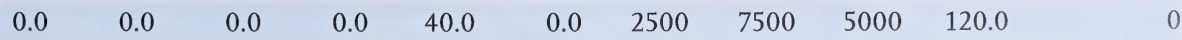

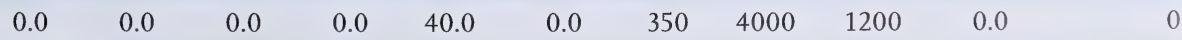

$\mathrm{TM}=$ trace mineralized

$\mathrm{DE}=$ Digestible Energy

$\mathrm{Ca}=$ Calcium

$\mathrm{P}=$ Phosphorus
$\mathrm{Mg}=$ Magnesium

$K=$ Potassium

$\mathrm{Na}=$ Sodium

$\mathrm{S}=$ Sulphur
$\mathrm{Cu}=$ Copper

$\mathrm{Zn}=\mathrm{Zinc}$

$\mathrm{Mn}=$ Manganese

$\mathrm{Se}=$ Selenium 


\section{APPENDIX 2. Daily Nutrient Requirements for Horses of Different Mature Weights}

Source: National Research Council's Nutrient Requirements of Horses (2007)

Appendix 2A. Daily nutrient requirements for ponies-200 kg (440 Ibs)

\begin{tabular}{|c|c|c|c|c|c|c|c|c|}
\hline Animal & Weight & $\begin{array}{l}\text { Daily } \\
\text { Eain } \\
\text { (lats) }\end{array}$ & $\begin{array}{l}\text { DE } \\
\text { (MICal) }\end{array}$ & $\begin{array}{l}\text { Eronis } \\
\text { Drotein } \\
\text { (19) }\end{array}$ & $\begin{array}{l}\text { Lysine } \\
\text { (E) }\end{array}$ & $\begin{array}{l}\text { Calionm } \\
\text { (g) }\end{array}$ & $\begin{array}{l}\text { Phos: } \\
\text { pliorites } \\
\text { (하 }\end{array}$ & $\begin{array}{l}\text { Vithmin } \\
\text { A fiogo } \\
\text { iv) }\end{array}$ \\
\hline \multicolumn{9}{|c|}{ Mature Horses } \\
\hline Maintenance & 200 & & 6.7 & 216 & 9 & 8 & 6 & 6 \\
\hline $\begin{array}{l}\text { Stallions } \\
\text { (breeding season) }\end{array}$ & 200 & & 8.7 & 316 & 14 & 12 & 7 & 9 \\
\hline \multicolumn{9}{|l|}{ Pregnant mares } \\
\hline 9 months & 214 & & 7.7 & 319 & 14 & 15 & 11 & 12 \\
\hline 10 months & 219 & & 8.1 & 336 & 15 & 15 & 11 & 12 \\
\hline 11 months & 226 & & 8.6 & 357 & 16 & 15 & 11 & 12 \\
\hline \multicolumn{9}{|l|}{ Lactating mares } \\
\hline $\begin{array}{l}\text { Foaling to } \\
3 \text { months }\end{array}$ & 200 & & 12.7 & 612 & 34 & 24 & 12 & 12 \\
\hline $\begin{array}{l}3 \text { months to } \\
\text { weaning }\end{array}$ & 200 & & 11.3 & 506 & 29 & 15 & 10 & 12 \\
\hline \multicolumn{9}{|l|}{ Working horses } \\
\hline Light work ${ }^{a}$ & 200 & & 8.0 & 280 & 12 & 12 & 7 & 9 \\
\hline Moderate work ${ }^{b}$ & 200 & & 9.3 & 307 & 13 & 14 & 8 & 9 \\
\hline Intense work ${ }^{c}$ & 200 & & 13.8 & 402 & 17 & 16 & 12 & 9 \\
\hline \multicolumn{9}{|c|}{ Growing Horses } \\
\hline 4 months & 67 & 0.34 & 5.3 & 268 & 12 & 16 & 9 & 3 \\
\hline 6 months & 86 & 0.29 & 6.2 & 270 & 12 & 16 & 9 & 4 \\
\hline 12 months & 128 & 0.18 & 7.5 & 338 & 15 & 15 & 8 & 6 \\
\hline \multicolumn{9}{|c|}{ Long yearling, 18 months } \\
\hline Not in training & 155 & 0.11 & 7.7 & 320 & 14 & 15 & 8 & 8 \\
\hline In training & 155 & 0.11 & 10 & 362 & 16 & 15 & 8 & 8 \\
\hline \multicolumn{9}{|c|}{ Two-year-old, 24 months } \\
\hline Not in training & 172 & 0.07 & 7.5 & 308 & 13 & 15 & 8 & 9 \\
\hline In training & 172 & 0.07 & 9.9 & 355 & 15 & 15 & 8 & 9 \\
\hline In training & 172 & 0.07 & 9.9 & 355 & 15 & 15 & 8 & 9 \\
\hline
\end{tabular}


Appendix 2B. Daily nutrient requirements for horses of different mature weights-400 kg (880 lb)

\begin{tabular}{|c|c|c|c|c|c|c|c|c|}
\hline Animal & Worght & $\begin{array}{l}\text { Dally } \\
\begin{array}{l}\text { Puini } \\
(4 y)\end{array}\end{array}$ & $\begin{array}{l}\text { DE } \\
(M E) \mid\end{array}$ & $\begin{array}{l}\text { srodic } \\
\text { Iroidin } \\
\text { fit }\end{array}$ & $\begin{array}{l}\text { Lpaine } \\
\text { (g) }\end{array}$ & $\begin{array}{l}\text { exrium } \\
\text { (g) }\end{array}$ & $\begin{array}{l}\text { Play } \\
\text { phumt } \\
\text { (b) }\end{array}$ & 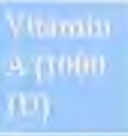 \\
\hline \multicolumn{9}{|c|}{ Mature Horses } \\
\hline Maintenance & 400 & & 13.3 & 504 & 22 & 16 & 11 & 16 \\
\hline $\begin{array}{l}\text { Stallions } \\
\text { (breeding season) }\end{array}$ & 400 & & 17.4 & 631 & 27 & 24 & 14 & 18 \\
\hline \multicolumn{9}{|l|}{ Pregnant mares } \\
\hline 9 months & 427 & & 15.4 & 637 & 27 & 29 & 21 & 16 \\
\hline 10 months & 439 & & 16.2 & 673 & 29 & 29 & 21 & 16 \\
\hline 11 months & 453 & & 17.1 & 714 & 31 & 29 & 21 & 16 \\
\hline \multicolumn{9}{|l|}{ Lactating mares } \\
\hline $\begin{array}{l}\text { Foaling to } \\
3 \text { months }\end{array}$ & 400 & & 25.3 & 1224 & 68 & 47 & 31 & 20 \\
\hline $\begin{array}{l}3 \text { months to } \\
\text { weaning }\end{array}$ & 400 & & 22.7 & 1064 & 57 & 32 & 20 & 20 \\
\hline \multicolumn{9}{|l|}{ Working horses } \\
\hline Light work a & 400 & & 16.0 & 559 & 24 & 24 & 15 & 16 \\
\hline Moderate work ${ }^{b}$ & 400 & & 18.6 & 614 & 26 & 26 & 17 & 18 \\
\hline Intense work ${ }^{c}$ & 400 & & 27.6 & 804 & 35 & 32 & 23 & 20 \\
\hline \multicolumn{9}{|c|}{ Growing Horses } \\
\hline $\begin{array}{l}\text { Weanling, } \\
4 \text { months }\end{array}$ & 135 & 0.67 & 10.6 & 535 & 23 & 31 & 17 & 7 \\
\hline $\begin{array}{l}\text { Weanling, } \\
6 \text { months }\end{array}$ & 173 & 0.58 & 12.4 & 541 & 23 & 31 & 17 & 9 \\
\hline $\begin{array}{l}\text { Yearling, } \\
12 \text { months }\end{array}$ & 257 & 0.36 & 15.0 & 677 & 29 & 30 & 17 & 13 \\
\hline \multicolumn{9}{|c|}{ Long yearling, 18 months } \\
\hline Not in training & 310 & 0.23 & 15.4 & 639 & 28 & 30 & 17 & 16 \\
\hline In training & 310 & 0.23 & 20.0 & 725 & 31 & 30 & 17 & 16 \\
\hline \multicolumn{9}{|c|}{ Two-year-old, 24 months } \\
\hline Not in training & 343 & 0.14 & 15.0 & 616 & 27 & 29 & 16 & 17 \\
\hline In training & 343 & 0.14 & 19.9 & 710 & 31 & 29 & 16 & 17 \\
\hline
\end{tabular}

axamples are horses used in Western and English pleasure riding, bridle path hack, equitation, etc.

${ }^{b}$ Examples are horses used in ranch work, roping, cutting, barrel racing, jumping, etc.

' Examples are horses used in race training, polo, etc. 
Appendix 2C. Daily nutrient requirements for horses of different mature weights-500 kg (1,100 lb)

\begin{tabular}{|c|c|c|c|c|c|c|c|c|}
\hline Anirital & Weighit & $\begin{array}{l}\text { Daily } \\
\text { Gain } \\
\text { (fag) }\end{array}$ & Iris & $\begin{array}{l}\text { Erimite } \\
\text { Poten } \\
\text { (a) }\end{array}$ & $\begin{array}{l}\text { Bs aline } \\
\text { (B) }\end{array}$ & (bi) & $\begin{array}{l}\text { Phan } \\
\text { phorus } \\
\text { (g) }\end{array}$ & $\begin{array}{l}\text { Vitamin } \\
\text { A(1000) } \\
\text { J11) }\end{array}$ \\
\hline \multicolumn{9}{|c|}{ Mature Horses } \\
\hline Maintenance & 500 & & 16.7 & 630 & 27 & 20 & 14 & 15 \\
\hline $\begin{array}{l}\text { Stallions } \\
\text { (breeding season) }\end{array}$ & 500 & & 21.8 & 789 & 34 & 30 & 18 & 22 \\
\hline \multicolumn{9}{|l|}{ Pregnant mares } \\
\hline 9 months & 534 & & 19.2 & 797 & 34 & 36 & 26 & 30 \\
\hline 10 months & 548 & & 20.2 & 841 & 36 & 36 & 26 & 30 \\
\hline 11 months & 566 & & 21.4 & 893 & 38 & 36 & 26 & 30 \\
\hline \multicolumn{9}{|l|}{ Lactating mares } \\
\hline $\begin{array}{l}\text { Foaling to } \\
3 \text { months }\end{array}$ & 500 & & 31.7 & 1530 & 84 & 59 & 38 & 30 \\
\hline $\begin{array}{l}3 \text { months to } \\
\text { weaning }\end{array}$ & 500 & & 28.3 & 1330 & 71 & 40 & 25 & 30 \\
\hline \multicolumn{9}{|l|}{ Working horses } \\
\hline Light work ${ }^{a}$ & 500 & & 20.0 & 699 & 30 & 30 & 18 & 22 \\
\hline Moderate work ${ }^{b}$ & 500 & & 23.3 & 768 & 33 & 35 & 21 & 22 \\
\hline Intense work ${ }^{c}$ & 500 & & 34.5 & 1004 & 43 & 40 & 29 & 22 \\
\hline \multicolumn{9}{|c|}{ Growing Horses } \\
\hline $\begin{array}{l}\text { Weanling, } \\
4 \text { months }\end{array}$ & 168 & 0.84 & 13.3 & 669 & 29 & 39 & 22 & 8 \\
\hline $\begin{array}{l}\text { Weanling, } \\
6 \text { months }\end{array}$ & 216 & 0.72 & 15.5 & 676 & 29 & 39 & 22 & 10 \\
\hline $\begin{array}{l}\text { Yearling, } \\
12 \text { months }\end{array}$ & 321 & 0.45 & 18.8 & 846 & 36 & 38 & 21 & 15 \\
\hline \multicolumn{9}{|c|}{ Long yearling, 18 months } \\
\hline Not in training & 387 & 0.29 & 19.2 & 799 & 34 & 37 & 21 & 18 \\
\hline In training & 387 & 0.29 & 25.0 & 906 & 39 & 37 & 21 & 18 \\
\hline \multicolumn{9}{|c|}{ Two-year-old, 24 months } \\
\hline Not in training & 429 & 0.18 & 18.7 & 770 & 33 & 37 & 21 & 20 \\
\hline In training & 429 & 0.18 & 24.8 & 888 & 38 & 37 & 21 & 20 \\
\hline
\end{tabular}

axamples are horses used in Western and English pleasure riding, bridle path hack, equitation, etc.

Examples are horses used in ranch work, roping, cutting, barrel racing, jumping, etc.

Examples are horses used in race training, polo, etc. 
Appendix 2D. Daily nutrient requirements for horses of different mature weights.600 kg (1,320 lbs)

\begin{tabular}{|c|c|c|c|c|c|c|c|c|}
\hline Animal & Wistsit & $\begin{array}{l}\text { D-iify } \\
\text { Grath } \\
\langle\mathrm{g} g\rangle\end{array}$ & $\begin{array}{l}\text { DEE } \\
\text { (Miei) }\end{array}$ & 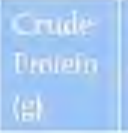 & $\begin{array}{l}\text { Lybine } \\
\text { (19) }\end{array}$ & $\begin{array}{l}\text { caterim } \\
\text { (g) }\end{array}$ & $\begin{array}{l}\text { Thion: } \\
\text { Whorys } \\
\text { (git }\end{array}$ & 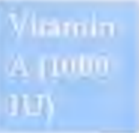 \\
\hline \multicolumn{9}{|c|}{ Mature Horses } \\
\hline Maintenance & 600 & & 20.0 & 756 & 33 & 24 & 17 & 18 \\
\hline $\begin{array}{l}\text { Stallions } \\
\text { (breeding season) }\end{array}$ & 600 & & 26.1 & 947 & 41 & 36 & 22 & 27 \\
\hline \multicolumn{9}{|l|}{ Pregnant mares } \\
\hline 9 months & 641 & & 23.1 & 956 & 41 & 43 & 32 & 36 \\
\hline 10 months & 658 & & 24.2 & 1009 & 43 & 43 & 32 & 36 \\
\hline 11 months & 679 & & 25.7 & 1072 & 46 & 43 & 32 & 36 \\
\hline \multicolumn{9}{|l|}{ Lactating mares } \\
\hline $\begin{array}{l}\text { Foaling to } \\
3 \text { months }\end{array}$ & 600 & & 38.0 & 1836 & 101 & 71 & 46 & 36 \\
\hline $\begin{array}{l}3 \text { months to } \\
\text { weaning }\end{array}$ & 600 & & 34.0 & 1596 & 86 & 47 & 30 & 36 \\
\hline \multicolumn{9}{|l|}{ Working horses } \\
\hline Light work $^{\text {a }}$ & 600 & & 24.0 & 839 & 36 & 36 & 22 & 27 \\
\hline Moderate work ${ }^{b}$ & 600 & & 28.0 & 921 & 40 & 42 & 25 & 27 \\
\hline Intense work ${ }^{c}$ & 600 & & 41.4 & 1205 & 52 & 48 & 35 & 27 \\
\hline \multicolumn{9}{|c|}{ Growing Horses } \\
\hline $\begin{array}{l}\text { Weanling, } \\
4 \text { months }\end{array}$ & 202 & 1.01 & 15.9 & 803 & 35 & 47 & 26 & 9 \\
\hline $\begin{array}{l}\text { Weanling, } \\
6 \text { months }\end{array}$ & 258 & 0.87 & 18.6 & 811 & 35 & 46 & 26 & 12 \\
\hline $\begin{array}{l}\text { Yearling, } \\
12 \text { months }\end{array}$ & 385 & 22.5 & 22.5 & 1015 & 44 & 45 & 25 & 17 \\
\hline \multicolumn{9}{|c|}{ Long yearling, 18 months } \\
\hline Not in training & 465 & 0.34 & 23.1 & 959 & 41 & 45 & 25 & 21 \\
\hline In training & 465 & 0.34 & 30.0 & 1087 & 47 & 45 & 25 & 21 \\
\hline \multicolumn{9}{|c|}{ Two-year-old, 24 months } \\
\hline Not in training & 515 & 0.22 & 22.4 & 924 & 40 & 44 & 24 & 24 \\
\hline In training & 515 & 0.22 & 29.8 & 1066 & 46 & 44 & 24 & 24 \\
\hline
\end{tabular}

a Examples are horses used in Western and English pleasure riding, bridle path hack, equitation, etc.

${ }^{b}$ Examples are horses used in ranch work, roping, cutting, barrel racing, jumping, etc.

c Examples are horses used in race training, polo, etc. 
Appendix 2E. Daily nutrient requirements for horses of different mature weights-900 kg (1,980 lbs)

\begin{tabular}{|c|c|c|c|c|c|c|c|c|}
\hline quìnal & Woight & $\begin{array}{l}\text { Daily } \\
\text { Gain } \\
\text { (kea) }\end{array}$ & $\frac{\text { DE }}{\text { (Mrgil) }}$ & $\begin{array}{l}\text { Crude } \\
\text { Drotcin } \\
\text { 타 }\end{array}$ & $\begin{array}{l}\text { Lyine } \\
\text { (9) }\end{array}$ & $\begin{array}{l}\text { Caluium } \\
\text { (g) }\end{array}$ & $\begin{array}{l}\text { Phos- } \\
\text { phorins } \\
\text { (s) }\end{array}$ & $\begin{array}{l}\text { Vihmin } \\
\text { A (1000) } \\
\text { iv) }\end{array}$ \\
\hline \multicolumn{9}{|c|}{ Mature Horses } \\
\hline Maintenance & 900 & & 30.0 & 1134 & 49 & 36 & 25 & 27 \\
\hline $\begin{array}{l}\text { Stallions } \\
\text { (breeding season) }\end{array}$ & 900 & & 39.2 & 1421 & 61 & 54 & 32 & 40 \\
\hline \multicolumn{9}{|l|}{ Pregnant mares } \\
\hline 9 months & 962 & & 34.6 & 1434 & 62 & 65 & 47 & 54 \\
\hline 10 months & 987 & & 36.4 & 1514 & 65 & 65 & 47 & 54 \\
\hline 11 months & 1019 & & 38.5 & 1607 & 69 & 65 & 47 & 54 \\
\hline \multicolumn{9}{|l|}{ Lactating mares } \\
\hline $\begin{array}{l}\text { Foaling to } \\
3 \text { months }\end{array}$ & 900 & & 54.3 & 2754 & 152 & 106 & 69 & 54 \\
\hline $\begin{array}{l}3 \text { months to } \\
\text { weaning }\end{array}$ & 900 & & 48.3 & 2394 & 128 & 72 & 44 & 54 \\
\hline \multicolumn{9}{|l|}{ Working horses } \\
\hline Light work ${ }^{a}$ & 900 & & 36.0 & 1259 & 54 & 54 & 33 & 41 \\
\hline Moderate work ${ }^{\mathrm{b}}$ & 900 & & 42.0 & 1382 & 59 & 63 & 38 & 41 \\
\hline Intense work ${ }^{c}$ & 900 & & 62.1 & 1808 & 78 & 72 & 52 & 41 \\
\hline \multicolumn{9}{|c|}{ Growing Horses } \\
\hline $\begin{array}{l}\text { Weanling, } \\
4 \text { months }\end{array}$ & 303 & 1.52 & 23.9 & 1204 & 52 & 70 & 39 & 14 \\
\hline $\begin{array}{l}\text { Weanling, } \\
6 \text { months }\end{array}$ & 389 & 1.30 & 28.0 & 1217 & 52 & 70 & 39 & 18 \\
\hline $\begin{array}{l}\text { Yearling, } \\
12 \text { months }\end{array}$ & 578 & 0.82 & 33.8 & 1522 & 66 & 68 & 38 & 26 \\
\hline \multicolumn{9}{|c|}{ Long yearling, 18 months } \\
\hline Not in training & 697 & 0.51 & 34.6 & 1438 & 62 & 67 & 37 & 31 \\
\hline In training & 697 & 0.51 & 45.0 & 1631 & 70 & 67 & 37 & 31 \\
\hline \multicolumn{9}{|c|}{ Two-year-old, 24 months } \\
\hline Not in training & 773 & 0.32 & 33.7 & 1386 & 60 & 66 & 37 & 35 \\
\hline In training & 773 & 0.32 & 44.7 & 1599 & 68 & 66 & 37 & 35 \\
\hline
\end{tabular}

axamples are horses used in Western and English pleasure riding, bridle path hack, equitation, etc.

Examples are horses used in ranch work, roping, cutting, barrel racing, jumping, etc.

Examples are horses used in race training, polo, etc. 


\section{GLOSSARY}

Acid Detergent Fibre (ADF) - is a measure of cellulose and lignin, two relatively undigestible types of fibre in a feed. The higher the ADF value, the lower the digestible energy in the feed. Timothy straw will have a higher ADF value than alfalfa hay.

Aerobic - occurring in the presence of oxygen.

Alfalfa - a perennial legume, Medicago sativa, also known as lucerne. Alfalfa is a highly digestible forage for horses, and has high protein content due to nitrogen-fixing bacteria in root nodules associated with its roots.

Alkalinity - the measure of the buffering capacity of a solution, especially to neutralize acids. Alkalinity is related to water hardness; as such, soft water is less alkaline than hard water. Alkaline solutions have high amounts of carbonates, usually from calcium carbonates.

Alkalosis - a condition where an excess of bicarbonate ions in the blood causes the $\mathrm{pH}$ of the blood to rise. The opposite of acidosis.

$\alpha$-amylase - a digestive enzyme produced by the pancreas that is involved in the digestion of carbohydrates, primarily starch.

Amino acid - organic compounds containing oxygen, hydrogen, carbon and nitrogen. There are 22 different amino acids and they link together in various combinations to produce different proteins.

Anaerobic - occurring in the absence of oxygen.

Anemia - a low amount of red blood cells in the body. As red blood cells carry oxygen from the lungs to the tissues, anemia results in weakness and fatigue.

\begin{abstract}
Angular limb deformities - condition caused by uneven growth in the growth plates of long bones, underdeveloped bones in the knee or hock or ligament tightness. In horses, typically, the cannon bone, knees or hock joints are affected, and result in an outward or inward deviation of the limbs as viewed from the front or back of the horse.
\end{abstract}

Antibodies - are produced by the white blood cells of the immune system. They are proteins that circulate in the blood and bind to foreign proteins, microorganisms or toxins in order to neutralize them. They are also called immunoglobins.

Anti-nutritional factor - a compound in a feed that has a negative effect on the nutritional value of the feed, and on the nutrition of the animal. An example is trypsin inhibitor found in soybeans. As it interferes with the horse's protein digestion, soybeans are toasted to nullify the trypsin inhibitor.

Antioxidant - is a substance that prevents compounds in feed from being oxidized and spoiling. Similarly, the function of an antioxidant in the body is to protect cellular components from being damaged by oxidation. Antioxidants work by preventing oxidative reactions or removing the reactive oxygen species before damage is done. For example, vitamin $\mathrm{E}$ and selenium in combination will protect against muscle degeneration (white muscle disease) or fat degeneration (yellow fat disease). The antioxidants vitamin $\mathrm{E}$ (tocopherols) and vitamin C (ascorbic acid) are commonly added to high fat feeds to protect them from spoiling. 
As-fed basis - it is the actual feed or feedstuff with moisture content included as fed to the animal before it is dried down to 100 per cent dry matter. Nutrient values on a feed tag are usually expressed on an as-fed basis. To convert to a dry matter basis, the value needs to be divided by the per cent dry matter content.

ATP - adenosine triphosphate (ATP) is the compound that transfers energy in the body. The energy contained in feed is transformed to ATP in the body, then ATP is stored and broken down to release energy to fuel reactions (i.e. muscle movement) in the body as needed.

Average daily gain (ADG) - the weight gained by an animal over a specific period of time (usually birth to weaning or weaning to yearling) divided by the time span in days.

Barren - a non-pregnant mare.

Big head disease (miller's disease) - a disease characterized by enlarged facial bones in the horse. The bones are enlarged due to leaching of the minerals in the bones, and replacement by fibrous connective tissue. The removal of minerals in the bones is due to an imbalance of phosphorus to calcium in the body, or a calcium deficiency.

Body condition score - a scoring system based on the appearance of the horse which assesses the horse's relative level of nutrition. A horse is in a good body condition score at 4 to 6 . A score below 4 signifies that the horse needs more energy in its diet, and above 6 suggests that the horse is receiving too much energy.

Bolt - a sudden movement by a horse either sideways or forwards in response to an unexpected stimulus. Also, when a horse bolts its feed, it means that the horse is eating it very fast.
Carbohydrates - compounds composed of carbon, hydrogen, and oxygen that include the non-structural carbohydrates, which are sugars and starches, and structural carbohydrates, the fibres, which are primarily cellulose and hemicellulose. Primary sources of sugars and starches are cereal grains.

Cellulose - a structural carbohydrate or fibre found in plants. Mammals do not have the cellulose enzyme needed to digest this fibre; as such, horses rely on the bacteria in the caecum and large intestine to ferment the cellulose found in grasses to obtain energy.

Chaff - a low quality feedstuff, similar to straw. It is the outer coverings, husks and portions of cereal plants that are left over when the seed is removed during the harvesting and combining of the cereal crop.

Colic - abdominal pain in the horse that can be caused by a number of different factors, such as parasites, carbohydrate overload due to excess grain, impaction in the intestinal tract due to sand or feed, ingestion of toxins, stress, illness or gas. It can be mild or severe, requiring surgical intervention and is the number one cause of death in the horse.

Colostrum - it is the nutrient-rich milk that is secreted before or at the time of foaling. It contains a large amount of antibodies that will help protect the foal from diseases. It is important that the newborn foal receives colostrum soon after birth, as the foal's ability to absorb these antibodies disappears within the first 48 hours of life.

Coumarol - a harmless compound found in yellow sweet clover. When the clover becomes moldy, the mold bacteria convert the coumarol into dicoumarol, which causes vitamin $\mathrm{K}$ deficiency and problems with blood clotting.

Concentrate - a feedstuff concentrated in highly digestible carbohydrates that is low in crude fibre. 
Creep feed - a highly nutritive feed for the nursing foal to supplement or replace the mother's milk.

Crude protein - the amount of crude protein in a feedstuff is a measure of the total nitrogen (N) content in the feedstuff, multiplied by 6.25. The horse's protein requirements are expressed as crude protein percentage or grams of crude protein. Feed tags commonly give the percentage of crude protein in the feed on an as-fed basis.

\section{Developmental Orthopaedic Diseases (DOD) -} A name for diseases of the limbs of growing horses, which include epiphysitis, angular limb deformities, osteochrondritis dessicans (OCD), and flexure deformities. These are caused by uneven growth in the growth plates of long bones, improper calcification of bones or ligament tightness. In horses, typically the cannon bone, pasterns, knees or hock joints are affected, and result in an outward or inward deviation of the limbs as viewed from the front or back of the horse or an "hour-glass shape." These problems, although primarily genetically inherited, can also be caused by conditions in utero or nutrition during growth. Typically, a diet too high in energy and soluble carbohydrates without proper protein and mineral supplementation is the cause.

Dicoumarol - a compound produced in moldy sweet clover which causes vitamin $\mathrm{K}$ deficiency in horses.

Digestible energy (DE) - the energy in a feed that the horse can digest and utilize for energy minus the energy lost in the feces.

Dough stage - a stage in plant development before the seeds reach maturity. It is after the milk stage when the material inside the seed is doughy.
Dry matter (DM) - this is the content of the feed without water, and the opposite of moisture content. The dry matter content and moisture content together will make up 100 per cent. Often, nutrient requirements are given as a proportion of their dry matter intake.

Electrolyte - typically minerals that are electrically charged in water. In horse nutrition, electrolytes are the macrominerals sodium, chlorine and potassium that are responsible for nerve conduction and fluid balance in the body. In hot climates or situations where the horse sweats excessively, electrolyte solutions can be given as supplements.

Endophyte - any bacteria or fungus that lives inside a plant in a symbiotic relationship. Some endophytes in plants pose health problems for horses. An endophyte-free variety is important when feeding horses, especially when choosing fescue grass.

Ensile - process of fermenting under anaerobic conditions, either cereal or hay. The feedstuff is typically placed in silos or tightly wrapped and sealed in plastic to protect it from oxygen. The feedstuff will be acted on by anaerobic bacteria to convert starches and fibre into volatile fatty acids, similar to the fermentation process that takes place in the large intestine of the horse or the rumen in ruminants.

Enzyme - a specialized protein that facilitates biochemical reactions in the body.

Epiphysis - the rounded end of a long bone is the epiphysis. The shaft of the long bone is called the diaphysis, and the middle portion of the bone between the diaphysis and the epiphysis is the metaphysis.

Epiphysitis - inflammation of an epiphysis or the cartilage that separates it from the shaft during growth. 
Ergot - a fungus that infects cereal grains and grasses, of which rye and triticale are most susceptible. The toxins produced by the fungus cause vasoconstriction, especially in the extremities, and result in gangrene (ears, tail and legs). It can also cause abortion in mares, colic, diarrhoea, incoordination and trembling.

Essential amino acids - amino acids that the horse cannot synthesize and are thus required in its diet.

Feed - a general term for that which is given to an animal to consume, whether a single feedstuff or a mixture, but excluding water.

Feedstuff - a single food fed to livestock, such as oats.

Ferritin - the concentration of ferritin in the blood is a measure of the amount of iron in the body. Ferritin is a protein that binds iron in the body organs for storage.

Forage - it is the primary feed source for horses. The horse needs to consume at least one per cent of its body weight in forage (on a dry matter basis) per day for a healthy digestive tract. Forage includes grasses, legumes and cereal plants, either fresh or dried, with or without their seeds. Forage is high in crude fibre.

Founder (laminitis) - a painful disease of the feet that is characterized by inflammation of the soft lamina of the hooves, which connect the bones of the feet to the hoof wall, providing a support mechanism for the weight of the horse. If left untreated, the hoof wall will separate from the coffin bone, causing rotation of the coffin bone through the sole of the hoof. It is characterized by a sawhorse stance, and heat in the front of the hoof. It is caused by many factors, including hoof concussion due to work on hard surfaces, cold water in a hot inactive horse, sudden carbohydrate overload, ingestion of black walnut shavings, turnout on lush pasture, or diseases such as insulin resistance and obesity.
Giardia - protozoa (microbe) that live in fecalcontaminated water sources. It causes stomach and intestinal illness, namely diarrhoea.

Girth - the distance around the body (rib cage) directly behind the shoulders where the girth or cinch would normally sit.

Gluten - is the majority of the protein contained within a cereal seed. It is the viscous material that remains when the starch is removed from the grain. Wheat is a primary source of gluten.

Goiter - is a condition that is caused by either by a deficiency or an excess of iodine in the diet or ingestion of goitrogenic substances. Foals can be born with goiter, if the mare had an iodine deficiency or consumed an excess of iodine during pregnancy. There is a visible lump or swelling at the throatlatch caused by an overactive thyroid gland.

Goitrogenic - goiter-causing substances.

Grab sample - a single sample taken at a moment in time that may not be representative of the sample as a whole. When taking a sample for feed analysis, it is important to take a representative sample over multiple areas, or a core sample from a hay bale, rather than a grab sample.

Grass staggers - see rye staggers.

Grass tetany - or also known as grass staggers or magnesium tetany, is caused by a low content or availability of magnesium in pasture or hay. Symptoms include nervousness, lack of coordination, muscular spasms, staggering and death.

Gross energy (GE) - the amount of energy released by the combustion of a specified quantity of feed. This value does not take into account the portion of the feed energy that is digestible and available for energy in that animal. 
Haylage - ensiled grass or legume plants that are cut, then not allowed to dry before being sealed in a container or wrapped tightly in plastic coverings to protect them from oxygen. The hay is then fermented or ensiled by bacteria under anaerobic conditions. If ensiled properly, haylage is a good quality feed for horses.

\section{Heaves (chronic obstructive pulmonary} disease or COPD) - damage to the lungs that causes reduced lung elasticity and difficult respiration. Expiration causes the most difficulty. When the condition is chronic, there is a "heave line" apparent across the bottom of the rib cage. It is commonly caused by allergic reactions and long-term exposure to dusts and molds.

Hemoglobin - an iron-containing protein that carries oxygen to the tissues through the blood.

Hormone - compounds synthesized by endocrine glands in the body and secreted into the blood to elicit a response in an target organ or tissue. Examples of hormones are insulin, growth hormone, prolactin and thyroid hormone.

Hulls - hard outer covering of grain.

Hydrochloric acid - a strong acid ( $\mathrm{HCl}$ ). It is present in the stomach and used to lower the $\mathrm{pH}$ of the stomach contents for the purposes of protein digestion.

\section{Hyperkalemic periodic paralysis (HYPP) -} also known as Impressive syndrome, it is a muscular disease that is caused by a hereditary genetic defect that causes temporary paralysis. Found solely in quarter horses due to extensive breeding of the stallion "Impressive." It is caused by the inability to regulate potassium in the blood, affecting sodium channels and ultimately muscle contraction. The condition can be controlled in horses with HYPP by low potassium diets.
Insulin - a protein hormone synthesized by the islet cells in the pancreas and secreted into the blood where it regulates glucose metabolism. It is deficient in diabetes mellitus.

Insulin resistance - occurs when the normal amount of insulin secreted is not enough to elicit a proper response from target cells and tissues. Increased circulating insulin and glucose concentrations in the body will cause a metabolic syndrome and complications such as laminitis. Obese, idle horses and certain breeds of horse are predisposed to insulin resistance.

\section{Laminitis - see Founder}

Legumes - forage plants such as alfalfa (lucerne), clovers, birdsfoot trefoil, and vetches that contain higher protein compared to grasses.

Lethargy - a lack of mental alertness and physical activity.

Lignin - a complex carbohydrate that gives structure to plants and is indigestible by animals.

Lipids - organic compounds containing carbon, hydrogen and oxygen which include the fats, oils, waxes, sterols, and triglycerides that are insoluble in water.

Macrominerals - minerals that the body needs in large amounts (per cent in diet or in grams/ kilogram of feed) to stay healthy. These are calcium, phosphorus, magnesium, potassium, sulphur, sodium and chlorine.

Metabolizable energy (ME) - The energy in a feed that is available to the animal; it is the digestible energy of the feed less the energy excreted in the feces, urine and gases of the animal. Energy values for chickens are typically given as metabolizable energy.

Microbes - microscopic living organisms, including bacteria, protozoa, viruses, and fungi. 
Microflora - microscopic plant life, including bacteria and some fungi.

Microminerals (trace minerals) - minerals that the body needs in small amounts (parts per million or milligram/kilogram of feed) for good health. These include iodine, cobalt, copper, zinc, iron, manganese, and selenium.

Milk stage - an early stage in plants when the seeds begin to form and contain a milky substance. With increased maturity the seed material becomes doughy (dough stage) and then fully mature.

Miller's disease - see big head disease.

Moisture content - the percentage of a feed that is water. The opposite of dry matter content.

Monogastric - an animal with a single compartment stomach. Humans, pigs and horses are monogastrics.

Mycotoxins - substances produced by molds or fungi under warm moist conditions in feed, which may cause harmful effects to horses.

Myeloencephalopathy - a disease that is characterized by degeneration of the nerve membranes. This is pronounced in the vertebrae, causing improper nerve conduction to the limbs. This is one of the causes of wobbler's disease resulting in lack of coordination of the limbs and weakness.

Net energy (NE) - is the metabolizable energy of a feed available to the horse minus the heat increment of feeding of that feed. The heat increment of feeding is the heat produced in the digestion of a feed. The net energy of a feed is then either used for maintenance (NEm) or for production (NEp).

Net energy of maintenance (NEm) portion of net energy required for maintenance of the horse's body systems, such as respiration, maintenance of body temperature, and organ function.
Net energy of production (NEp) - the portion of net energy above maintenance needed for production, such as growth, lactation, reproduction and performance.

Nitrogen free extract (NFE) - an estimate of soluble carbohydrates in a feed, including the sugars and starches. This does not include the fibres or insoluble carbohydrates.

Nitrate poisoning - Nitrate poisoning is caused by ingestion of water, but mainly feed containing high levels of nitrates. Nitrates are converted into nitrites in the horse, which if absorbed into the bloodstream, cause haemoglobin to be unable to bind oxygen. Symptoms of nitrate poisoning are respiratory difficulties, and dark brown urine. If untreated, nitrate poisoning can lead to death. Nitrates can accumulate in crops that have been subjected to drought, stress, frost or high levels of nitrogen fertilization. Horses can tolerate up to two per cent of nitrate in their diet.

Non-essential amino acids - amino acids that the horse can synthesize to meet its requirements and are thus not needed in its diet.

Non-protein nitrogen (NPN) - nitrogen that comes from inorganic sources, such as urea and ammonia and not from protein sources. Ruminants such as cattle can utilize NPN in their diet to make animal protein through the microbes in their rumen. Horses cannot utilize NPN, and it is of little value to them.

Non-structural carbohydrates - simple carbohydrates in plants that include glucose, fructose, sucrose, fructan and starch. Structural carbohydrates are the fibrous parts of plants.

Nutrient - a chemical compound that the horse's body needs to function and grow. The major nutrients are water, protein, fat, carbohydrates, vitamins, and minerals. 
Osteomalacia - lack of calcification in the bones of mature horses caused by inadequate dietary vitamin $\mathrm{D}$, calcium and phosphorus or an incorrect calcium to phosphorus ratio in the diet. Bones are weak and brittle.

Palatability - the characteristic relating to how desirable a feed is to consume involving taste, texture, smell etc.

Parakeratoses - a skin condition characterized by dry, rough, flaky skin. Can arise from a zinc deficiency in horses.

Pepsin - enzyme secreted in the stomach that breaks down proteins.

Peptide - any compound consisting of two or more amino acids; the building blocks of proteins.

Pharynx - is located at the rear of the mouth before the esophagus. Once food has passed into the pharynx, it cannot return to the mouth.

Pro-vitamin - a substance found in feed that is converted into a vitamin by animal tissues. Beta-carotene is the pro-vitamin form of vitamin $\mathrm{A}$.

Pulse crop - these are pod-bearing legumes such as beans and peas. Pulses are similar in energy content to cereal grains, but are high in good quality protein. However, some pulse crops (typically the older varieties) may contain anti-nutritional factors that need to be destroyed by heat processing.

Rhabdomyolysis (tying up) - difficulty moving due to muscle stiffness and cramping typically after a strenuous bout of exercise. Some horses may have a disorder such as polysaccharide storage myopathy where tying up occurs regularly and has to be nutritionally managed. A horse with rhabdomyolysis has dark brown urine due to the breakdown of myoglobin in muscle.
Rickets - inadequate calcification in the bones of growing horses caused by inadequate dietary vitamin $\mathrm{D}$, calcium and phosphorus or an incorrect calcium to phosphorus ratio in the diet.

Roughage - feed that is high in crude fibre, which includes forages as well as beet and fruit pulps.

Ruminant - animals with four-chambered stomachs that enable them to digest fibre. Horses digest fibre in their hindgut, but ruminants digest fibre in their foregut or rumen due to the presence of microbes in their rumen. Unlike horses, ruminants can absorb proteins synthesized by these microbes, even though they do not provide a good source of protein. Cows, goats, sheep, bison, deer, camels, llamas, and giraffes are all ruminants.

Rye staggers - also known as perennial ryegrass staggers or grass staggers, is a condition caused by the ingestion of contaminated ryegrass in pasture. The ryegrass is infected with an endophyte, which produces a toxin that poisons the nervous system causing tremors and lack of coordination.

Saline - containing salt.

Salinity - an estimate of the amount of salt dissolved in water.

Salmonella - bacteria that causes gastrointestinal diseases in animals, including horses and humans. It is transmitted to horses through contaminated feces and causes colic and diarrhoea.

Silage - forage that is ensiled or fermented under anaerobic conditions and fed to cattle and horses. The ensiled forage can consist entirely of hay (haylage) or contain cereal plants (more commonly termed silage). 
Slobbers - when horses ingest moldy clover, slobbers result from the toxin that the fungus produces. The horse salivates excessively, and there is excessive tear production, urination and, sometimes, diarrhoea.

Straw - the stalks of cereal and grass plants after the seeds are removed. Straw is very high in fibre and low in digestible energy and protein, and has little nutritional value for horses.

\section{Structural carbohydrates (complex) -} are the complex carbohydrates that provide structure in plants. These are the fibres including cellulose, hemicellulose, and lignin that are the neutral detergent fibre portion in feed analyses.

Sulphates - chemical compounds containing sulphur and oxygen $\left(\mathrm{SO}_{4}\right)$. High amounts of sulphates in water can cause diarrhoea in horses. Growing horses and pregnant and lactating mares are most susceptible.

Symbiotic - a relationship in which two or more different organisms live in close association that is either positive or neutral for the organisms involved.

Synchronous diaphragmatic flutters (thumps) is a contraction of the diaphragm in synchrony with the heart beat, like horse hiccups. It is seen in fatigued horses after prolonged exercise, such as endurance riding. Prolonged sweating causes an electrolyte imbalance (lack of sodium, chlorine, potassium, and calcium) or acid-base imbalance in the blood.

Tannins - an anti-nutritional factor found in some feeds. Tannins are a bitter compound that may reduce the palatability and digestibility of feeds for horses.

Thermoregulation - the maintenance of a narrow range of body temperature.

\section{Total digestible nutrients (TDN) -}

a complex measure of the available nutrients in feeds, an older system now replaced by digestible energy.. Determined by adding digestible crude protein (DCP), digestible nitrogen-free extract (DNFE), and digestible crude fibre (DCF) plus 2.25 times digestible ether extract (DEE).

$\mathrm{TDN}=\mathrm{DCP}+\mathrm{DNFE}+\mathrm{DCF}+2.25$ (DEE).

Total dissolved solids (TDS) - a good indicator of water quality and suitability for consumption is the TDS. The TDS is the sum of the concentration of all substances dissolved in the water. The safe upper limit of TDS for horses is 6,500 ppm (parts per million or $\mathrm{mg} / \mathrm{L}$ ); however, water for horses should ideally be less than 5,000 ppm.

Thumps (synchronous diaphragmatic flutters) see synchronous diaphragmatic flutters.

\section{Trace minerals (microminerals) -} see microminerals.

Tying up - see rhabdomyolysis.

Volatile fatty acid (VFA) - these are the end products of fermentation of fibre in the caecum and large intestine. The major volatile fatty acids are acetate, propionate and butyrate that are absorbed and used as sources of energy for the horse.

White muscle disease - degenerative disease of the cardiac and skeletal muscles caused by low levels of selenium and also vitamin $\mathrm{E}$.

Wobbler's disease - a condition where nerves in the vertebrae are compressed and affect movement of the limbs. This condition has varying causes, such as degeneration of nerve membranes (myeloencephalopathy), or malformation of the vertebrae (orthopaedic diseases).

Wolf teeth - these are the first premolars in the cheek teeth of the horse's mouth. They are small teeth that sometimes interfere with the bit placement in the horse's mouth and are usually removed. 


\section{REFERENCES AND FURTHER READING/RESOURCES}

\section{Alberta Agriculture and Rural Development Publications:}

\section{pabliturition}

What's the Score? Body Condition Scoring for Livestock (2004)

Alocise 패

Water Requirements for Livestock (2005)

CD400/40-1 (CD ROM)

Body Condition Scoring Your Horse (2004)

400/716-1

Manure and Pasture Management for Horse Owners (2003)

$460 / 20-1$

Feeding Young Horses for Sound Growth (2004)

$460 / 27-1$

Feeding the Stallion (2005)

$460 / 50-2$

Feeding the Broodmare (2005)

$460 / 50-3$

Horse Health (1999)

$460 / 50-6$

Horse Handling Facilities (2001)

$460 / 661-2$

$460 / 722-1$

To order both free and priced Alberta Agriculture and Rural Development publications, call 1-800 292-5697 (toll-free in Canada) or visit www.agriculture.gov.ab.ca/publications.

\section{Other Resources}

Canadian Agri-Food Research Council, (1998).

Recommended Code of Practice for the Care and Handling of Farm Animals.

Carroll, C.L. and Huntington, P.L. (1988). Body Condition Scoring and Weight Estimation of Horses. Equine Veterinary Journal 20: 41-45.

Coleman, B. (2003). My Horse Needs Minerals But Which Ones? www1.agric.gov.ab.ca/\$department/deptdocs.nsf/all/hrs6288

Frape D. L. (2004). Equine Nutrition and Feeding, Oxford, UK: Blackwell Publishing.

Henneke. D.R., Potter, G.D. Kreider, J.L. and Yeates, B.F. (1983). Relationship Between Condition Score, Physical Measurement and Body Fat Percentage in Mares. Equine Veterinary Journal. 15: $371-372$.

Lewis L.D. (1995). Equine Clinical Nutrition: Feeding and Care.

Philadelphia, PA: Lippincott Williams and Wilkins.

National Research Council. (1989). Nutrient Requirements of Horses.

Washington, DC: The National Academies Press.

National Research Council. (2007). Nutrient Requirements of Horses.

Washington, DC: The National Academies Press. Appendix 2 is adapted and reprinted with permission from the National Academies Press, Copyright [2007], National Academy of Sciences. 
Pearse, S. G., E. C. Firth, N. D. Grace, \& P. F. Fennessey. (1998). Effect of Copper Supplementation on the Evidence of Developmental of Othopedic Disease in Pasture-fed New Zealand Thoroughbreds. Equine Veterinary Journal 30(3).

Ralston, S (2001). The Geriatric Horse. (Proceedings of the Horse Breeders and Owners Conference, Red Deer, AB, Canada, 2001).

Ralston, S.L. (2001). Care for the Older Horse: Diet and Health. In: Recent Advances in Equine Nutrition. S.L.Ralston and H.F. Hintz (eds) International Veterinary Information Service, Ithaca, New York, USA.

Warren, L. (2006). What's for Dinner? Choosing the Right Feed for Your Horse. (Proceedings of the Horse Breeders and Owners Conference, Red Deer, AB, Canada, 2006). 


\section{NOTES}




\section{NOTES}





\section{Help. Wherever, whenever.}

\section{agricultule.ogovab.ca}

Use our on-line decisionmaking resources for your farm and agri-business.

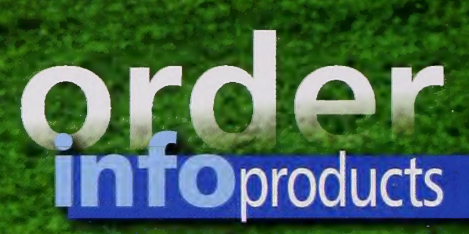

Order free publications and buy our books, manuals, videos and CDs by calling 1-800-292-5697. or on-line at agriculture.gov.ab.ca/publications.

\section{call of the and}

Tune in Monday to Friday for our noon-hour agriculture radio show broadcast on 27 Alberta radio stations.

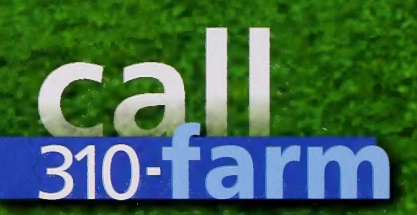

Talk to our agriculture specialists at the Ag-Info Centre (310-3276).

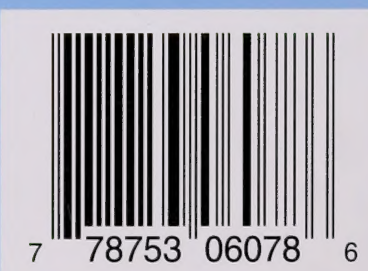

